\title{
MORFOLOGIA DOS IMATUROS E CICLO EVOLUTIVO DE ANACASSIS DUBIA (BOHEMAN), A. FUSCATA (KLUG), $A$. LANGUIDA (BOHEMAN), A. PHAEOPODA BUZZI E A. PUNCTULATA (KLUG) (COLEOPTERA, CHRYSOMELIDAE, CASSIDINAE) ${ }^{1}$
}

\author{
Zundir José Buzzi ${ }^{2}$
}

\begin{abstract}
MORPHOLOGY OF THE IMATURES AND LIFE CYCLE OF ANACASSIS DUBIA (BoHeman), A. FUSCATA (Klug), A. LANGUIDA (BOHEMAN), A. PHAEOPODA BuZZI AND A. punctullata (Klug) (Coleoptera, Chry Somel.idae, CAssidinaE). Eggs, fifth instar larvae and pupae of A.dubia (Boheman, 1854), A. fuscata (Klug, 1829), A.languida (Boheman, 1854), A. phaeopoda Buzzi, 1976 and A. punctulata (Klug, 1829) are described. Imatures stages were reared in a stove Biometron under temperature of $25 \pm 2^{\circ} \mathrm{C}$, photophase of 12 hours and relative humidity of $80 \pm 5 \%$. The larvae of $A$. dubia and $A$. languida were fed with leaves of Baccharis retusa DC; A. fuscata with leaves of Baccharidastrum argutum (Less) Cabrera; A. phaeopoda with leaves of Baccharis gaudichaudiana DC. and larvae of A. punctulata with leaves of Baccharis trimera (Less) A. DC.. All plants belonging to the Asteraceae. Two forms of A. fuscata were studied: A. fuscata (Klug, 1829) and A. fuscata form=unicolor (Burmeister, 1870) n.syn. and no significant differences were found.

KEY WORDS. Coleoptera, Chrysomelidae, Cassidinae, Anacassis, imatures, life cycle
\end{abstract}

\section{CONTEÚDO}

INTRODUÇÃo . . . . . . . . . . . . . . . . . . . . . . . . . . 216

Revisão bibliográfica .................................217

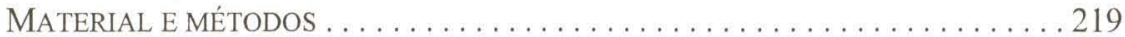

Identificação das espécies . . .......................... 220

Criação estoque .................................. 220

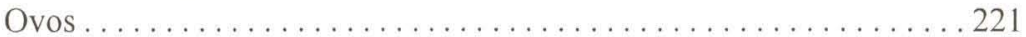

Larvas ...................................221

Pupas....................................222

Curva de Esperança de Vida e de Sobrevivência ............... 222

Análise estatística ................................223

RESULTADOS E DISCUSSÃO . . . . . . . . . . . . . . . . . . 223

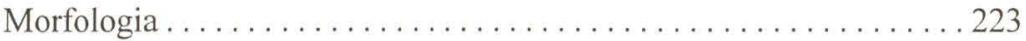

Anacassis dubia (Boheman, 1854) ..................... 223

1) Contribuição número 920 do Departamento de Zoologia, Universidade Federal do Paraná.

2) Departamento de Zoologia, Universidade Federal do Paraná. Caixa Postal 19020, 81531-990 Curitiba, Paraná, Brasil. Bolsista do CNPq. 
Anacassis fuscata (Klug, 1829) . . . . . . . . . . . . . . . . 227

Anacassis fuscata (Klug, 1829) (forma) . . . . . . . . . . . . 231

Anacassis languida (Boheman, 1854) ................. 232

Anacassis phaeopoda Buzzi, 1976 . ..................... 234

Anacassis punctulata (Klug, 1829) . . . . . . . . . . . . . . . . 239

Discussão . . . . . . . . . . . . . . . . . . . . . . . . . 242

Ovos................................... 242

Larvas . . . . . . . . . . . . . . . . . . . . . . . . . . . . . . 244

Pupas .....................................246

Chave para identificação das larvas de quinto ínstar de Anacassis . . . 248

Chave para identificação das pupas de Anacassis . . . . . . . . . . . . 248

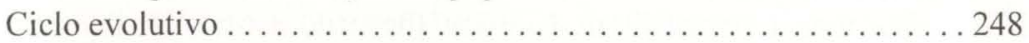

Período de incubação . . . . . . . . . . . . . . . . . . . . . 248

Número de ínstares e largura das cápsulas cefálicas . . . . . . . . . 249

Razão de crescimento . ...........................251

Duração dos ínstares e do estágio larval . . . . . . . . . . . . 252

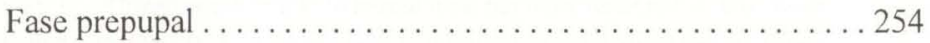

Duração do estágio pupal . . . . . . . . . . . . . . . . . . . 254

Duração do ciclo evolutivo . . . . . . . . . . . . . . . . . . . . . . 254

Curvas de Esperança de Vida . . . . . . . . . . . . . . . . . . . . 255

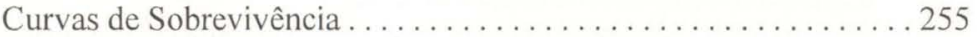

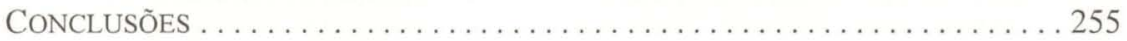

REFERÊNCIAS BIBLIOGRÁFICAS . . . . . . . . . . . . . . . . . . . . . . 257

Tabelas ................................................. 259

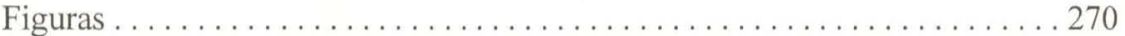

O estudo do ciclo evolutivo das espécies de Anacassis Spaeth, 1913 que vivem sobre plantas da família Asteraceae (=Compositae) é de suma importância. Isto é comprovado pelos estudos feitos nos Estados Unidos por BOLDT (1989b) concluindo que A. fuscata é um bom agente de controle biológico de Baccharis salicifolia (R. \& P.) Pers.. BoldT (1989a) recomenda que o controle de B. halimifolia Lin. seja feito através do uso de insetos fitófagos da América do Sul, entre os quais cita várias espécies de Anacassis. Na Austrália foram introduzidas cinco espécies de Anacassis para o controle de B. halimifolia, uma invasora de pastagens (MCFADYEN 1987).

Muitas espécies de Baccharis são utilizadas na indústria de perfumes, no controle da erosão, na medicina popular, como fonte de pólen para abelhas e na construção de cercas vivas; muitas causam danos como invasoras de pastagens e outras áreas, como competidoras, dificultando o trânsito da água em riachos, provocando assoreamento e muitas são tóxicas para os animais, como B. halimifolia, B. coridifolia DC. e B.megapotamica Sprengel (BOLDT 1989a). 
Das espécies de Asteraceae sobre as quais vivem as espécies de Anacassis estudadas na presente pesquisa, somente Baccharis trimera (Less) A. DC. e B. gaudichaudiana DC. conhecidas popularmente como carqueja, têm aplicação na medicina popular, enquanto $B$. retusa DC. pode ser considerada como séria invasora de áreas desmatadas como se pode constatar nas áreas de coleta, na Serra do Mar a $25 \mathrm{~km}$ de Curitiba, em São José dos Pinhais, ao longo da estrada entre Curitiba e Paranaguá (BR 277).

O estudo das fases ontogenéticas do ciclo evolutivo também se reveste de grande importância pois permite, muitas vezes, o estabelecimento de sinonímias ou é de grande valia na identificação de espécies cripticas.

Na presente pesquisa estudou-se os imaturos de várias espécies de Anacassis, objetivando: 1) fornecer subsídios para o estudo de agentes de controle biológico para várias espécies de Asteraceae; 2) descrever a morfologia dos ovos, larvas e pupas; 3) estabelecer Curvas de Sobrevivência e de Esperança de Vida, em laboratório; 4) determinar o período de incubação; 5) determinar o número e duração dos ínstares, duração do estágio larval e razão de crescimento; 6) estabelecer a duração do estágio pupal e a duração total do ciclo evolutivo; 7) comparar os imaturos de A. fuscata (Klug, 1829) com os imaturos de A. fuscata [forma=unicolor (Burmeister, 1870)].

\section{REVISÃO BIBLIOGRÁFICA}

\section{Distribuição geográfica}

As espécies do gênero Anacassis ocorrem na Argentina, Bolívia, Brasil e Paraguai segundo SPAETH (1914) e BlaCKWELdER (1946). As espécies estudadas na presente pesquisa apresentam a seguinte distribuição geográfica:

Anacassis dubia (Boheman, 1854) é encontrada no Brasil segundo os autores acima citados. Exemplares da Coleção de Entomologia Pe. J.S. Moure, Departamento de Zoologia, Universidade Federal do Paraná, apresentam etiquetas de procedência de São José dos Pinhais, Ponta Grossa (Paraná), Mafra e São Bento do sul - Rio Vermelho, (Santa Catarina).

Anacassis fuscata (Klug, 1829) é encontrada, segundo os autores acima citados, na Argentina, Brasil e Paraguai. BuZZI (1988) cita exemplares procedentes de Seara -Nova Teutônia (Santa Catarina), Curitiba (Paraná) e Paranapiacaba (São Paulo). Exemplares da Coleção de Entomologia Pe. J.S. Moure com etiquetas de procedência de Formosa, Missiones e Tucuman (Argentina); Mafra (Santa Catarina); Vilarrica e Itapuá (Paraguai) e Sauce (Uruguai, Departamento Canelones).

Anacassis fuscata unicolor (Burmeister, 1870) foi descrita de Mendoza (Argentina). Exemplares da Coleção de Entomologia Pe. J.S. Moure com etiquetas de procedência de Curitiba (Paraná) que por ser simpátrica com A. fuscata foi no presente trabalho considerada como uma forma e nominada A. fuscata (forma).

Anacassis languida (Boheman, 1854). Registrada como ocorrendo no Brasil. Segundo Buzzi (1988) ocorre em Mafra (Santa Catarina) e São José dos Pinhais (Paraná).

Anacassis phaeopoda Buzzi, 1976. Na descrição original da espécie o autor 
cita o holótipo e os parátipos de São José dos Pinhais (Paraná), São Bento do Sul Rio Natal, Corupá (Santa Catarina) e Vacaria (Rio Grande do Sul).

Anacassis punctulata (Klug, 1829). Segundo SPAETH (1914), ocorre no Sul do Brasil. Exemplares da Coleção de Entomologia Pe. J.S. Moure apresentam etiquetas de procedência de São José dos Pinhais e Ponta Grossa (Paraná), Corupá, Mafra e São Bento do Sul -Rio Vermelho (Santa Catarina).

\section{Plantas hospedeiras}

Todas as espécies do gênero Anacassis estudadas até o presente vivem sobre plantas da família Asteraceae (=Compositae).

Anacassis cribrum (Klug, 1829) vive sobre Baccharidastrum argutum (Less) Cabrera (Buzzi 1975a).

Anacassis dubia vive sobre Baccharis eleagnoides Steudel (BENNET 1963) e Baccharis retusa DC. (MCFADYEN 1987).

Anacasis fuscata vive sobre Baccharis gaudichaudiana DC., B. pingraea DC (MCFADYEN 1987), B. salicifolia (R. \& P.) (BOLDT 1989b) e Baccharidastrum triplinerve (Less) Cabrera (BuzZI 1975b) e MCFADYEN (1987). BOLDT (1989b) estudou a possibilidade de controle biológico de Baccharis salicifolia nos Estados Unidos através da introdução de $A$. fuscata proveniente da Argentina. Tentou criá-la em 34 espécies de plantas: 32 Asteraceae (19 Astereae; 1 Eupatorieae; 4 Heliantheae; 3 Helenieae; 3 Anthemideae; 1 Cynareae e 1 Cithorieae); 1 Asclepiadaceae e 1 Poaceae (=Gramineae)). Concluiu que $A$. fuscata apresenta alto grau de especificidade para $B$. salicifolia, não ataca nenhuma planta de importância econômica e que é muito apropriada utilizá-la no controle biológico desta planta. Em 1979 A. fuscata e A. fuscataunicolor foram introduzidas em Queensland (Austrália) para o controle biológico de Baccharis halimifolia mas sem sucesso (MCFADYEN 1987).

A. languida vive sobre Baccharis pauciflosculosa A.P.DC. e B. retusa (BUZZI \& GARCIA 1983).

A. phaeopoda vive sobre B. gaudichaudiana (BUZZI 1976) e MCFADYEN (1987) e Baccharidastrum triplinerve (MCFADYEN 1987).

A. prolixa (Boheman, 1854) vive sobre Baccharispingraea (MCFADYEN 1987) e B. spicata (Lam.) Baillon (LimA 1955). A. sulcipennis (Boheman, 1854) vive sobre Flourensia campestris Griseb (ARAVENA 1960).

\section{Fases de desenvolvimento}

Das 22 espécies de Anacassis citadas por BLACKWELDER (1946), somente se conhecem as fases de desenvolvimento ontogenético de quatro espécies.

Anacassis sulcipennis. ARAVENA (1960) descreve os ovos e faz considerações sobre o formato das posturas e o número de ovos nelas contidos, sua distribuição nas folhas da planta hospedeira e período de incubação de nove dias, em condições ambientais. Das larvas faz breves considerações morfológicas sobre cada ínstar, mostrando suas diferenças, gregarismo nos primeiros ínstares e duração do período larval que em condições ambientais é de 27 dias. Da pupa faz uma sucinta descrição e o período pupal varia de três a quatro dias "segun la temperatura".

Anacassis cribrum. BUZZI (1975a) descreve o ovo; apresenta medidas do ovo e do pedúnculo que o sustenta; descreve as posturas e o número de ovos ali 
encontrados, cuja média é 23,39; o período de incubação é 11,2 dias, sob temperatura de $23^{\circ} \mathrm{C}$.

Descreve detalhadamente a larva do quinto ínstar e em relação aos demais, faz breves referências, destacando as diferenças; a duração em dias, dos ínstares, do primeiro ao quinto, é respectivamente, sob $18^{\circ} \mathrm{C}$ e $23^{\circ} \mathrm{C}: 4,4 ; 3,4 ; 3,7 ; 4,1 ; 11,1 \mathrm{e}$ 3,$3 ; 2,9 ; 2,9 ; 4,5$ e 7,$5 ;$ a largura média da cápsula cefálica dos ínstares larvais é, em milímetros: 0,$54 ; 0,76 ; 1,03 ; 1,36$ e 1,81, não havendo sobreposição de medidas entre os vários ínstares.

Faz uma detalhada descrição da pupa; a duração do período pupal é, em média, 8,1 dias sob $23^{\circ} \mathrm{C}$ e 11,9 dias sob $18^{\circ} \mathrm{C}$.

Apresenta também um estudo correlacionando o peso da larva e da pupa, em função da idade; evidenciando um aumento muito grande de peso no quinto ínstar até a fase de prepupa, havendo em seguida uma queda de peso que continua no estágio pupal até a emergência do adulto.

Anacassis fuscata. BuZzI (1975b) descreve os estágios e seu desenvolvimento sob temperatura de $21,9^{\circ} \mathrm{C}$. Faz a descrição do ovo e menciona a duração média do período de incubação de 9,4 dias e o número médio de 19,2 ovos por postura.

Faz a descrição da larva de quinto ínstar e breves referências aos demais ínstares; a duração dos ínstares, do primeiro ao quinto, em dias, é respectivamente: 3,$1 ; 3,0 ; 2,8 ; 3,1$ e 5,0; a largura média, em milímetros, das cápsulas cefálicas dos instares larvais, do primeiro ao quinto ínstar, é repectivamente: 0,$49 ; 0,67 ; 0,92$; 1,22 e 1,65. Da pupa faz a descrição e a duração do período pupal é de 8,2 dias.

Anacassis languida. BuZZI \& GARCIA (1983) descrevem os estágios e dão algumas notas sobre o seu desenvolvimento sob temperaturas variando de 20 a $22,8^{\circ} \mathrm{C}$. Fazem a descrição do ovo e o período de incubação é 13,5 dias. Descrevem a larva de quinto ínstar; a largura das cápsulas cefálicas dos ínstares larvais, em milímetros, do primeiro ao quinto ínstar é, respectivamente: 0,$61 ; 0,86 ; 1,12 ; 1,51$ e 2,05; a duração do período larval é de 31,6 dias. Descrevem a pupa e a duração do período pupal é 11,5 dias.

\section{MATERIAL E MÉTODOS}

Todos os experimentos foram realizados em laboratório do Departamento de Zoologia da Universidade Federal do Paraná no período de setembro de 1992 a fevereiro de 1993. A temperatura média máxima ambiente, do laboratório, nesse período, foi de $24,05^{\circ} \mathrm{C}$, variando de 27,5 a $19^{\circ} \mathrm{C}$ e a temperatura média mínima, $22,23^{\circ} \mathrm{C}$, variando de 23,0 a $15,5^{\circ} \mathrm{C}$. A temperatura média desse período foi de $21,88^{\circ} \mathrm{C}$ e a umidade relativa foi, em média de $75 \pm 5 \%$. Para o estudo da duração das fases do ciclo evolutivo foi utilizada uma estufa Biometron com temperatura constante de $25 \pm 2^{\circ} \mathrm{C}$, fotofase de 12 horas e umidade relativa no interior da estufa de $80 \pm 5 \%$.

Imaturos de todas as espécies estudadas, foram fixados, para as descrições, desenhos e fotos, em Kahle-Dietrich, que tem a seguinte composição: água destilada, 300 partes; álcool, 95\%, 150 partes; formol, 50 partes; ácido acético glacial, 10 partes. 
As fotos foram feitas com auxílio de Aparelho para microfotografia marca "Tessovar" da Zeiss.

A terminologia utilizada nas descrições ou referências aos imaturos foi a encontrada em Boving \& Craighead (1931), Peterson (1960), Buzzi (1988) e Costa et al. (1988).

Foi estudado o ciclo evolutivo e foram descritos os imaturos (ovos, larvas de quinto ínstar e pupas) das seguintes espécies: Anacassis dubia (Boheman, 1854) (Fig. 1), A. fuscata (Klug, 1829) (Fig. 2), A. fuscata [forma=unicolor (Burmeister, 1870) de ora em diante nominada simplesmente A. fuscata (forma)] (Fig. 4), A. languida (Boheman, 1854) (Fig. 3), A. phaeopoda Buzzi, 1976 (Fig. 5) e $A$. punctulata (Klug, 1829) (Fig. 6).

De $A$. dubia descreveu-se também a larva de quarto ínstar, devido a grande diferença quando comparada com a de quinto ínstar.

\section{IDENTIFICAÇÃO DAS ESPÉCIES}

A identificação das espécies foi feita por comparação com espécimens identificados e depositados na Coleção de Entomologia Pe. J.S. Moure, Departamento de Zoologia, Universidade Federal do Paraná, por comparação com diapositivos feitos pelo Prof. Dr. Pe. Jesus Santiago Moure da coleção do "The Natural History Museum", Londres, Inglaterra e também confirmadas pelas descrições feitas por BOHEMAN $(1850,1854)$.

\section{CRIAÇÃo ESTOQUE}

Adultos de A. fuscata e A. fuscata (forma) foram coletados no Centro Politécnico, bairro Jardim das Américas, Curitiba e alimentados com folhas da planta hospedeira Baccharidastrum argutum (Less) Cabrera. Adultos de A. dubia e A. languida foram alimentados com Baccharis retusa DC., A. phaeopoda com Baccharis gaudichaudiana DC. e A. punctulata com Baccharis trimera (Less) A. DC.. Todas as plantas pertencentes à família Asteraceae (=Compositae). B. retusa, $B$. gaudichaudiana, $B$. trimera foram coletadas, juntamente com formas imaturas, a 25km de Curitiba, ao longo da BR 277, na Serra do Mar, em São José dos Pinhais (Paraná).

Adultos de A. punctulata trazidos do campo e mantidos em laboratório, não ovipositaram e adultos de $A$. dubia e $A$. languida ovipositaram uma única vez.

Todos os adultos foram mantidos, em laboratório, sob temperatura ambiente, em copos de plástico, de formato tronco-cônico, medindo $10 \mathrm{~cm}$ de diâmetro, na altura do meio, por $11 \mathrm{~cm}$ de altura e como tampa utilizou-se filme plástico transparente.

$\mathrm{O}$ alimento fornecido era trocado a cada três dias e consistia de um pequeno ramo da planta hospedeira com algumas folhas; o ramo era mergulhado num frasco de $2 \times 3 \mathrm{~cm}$, com tampa perfurada, por onde era introduzida a base do ramo, contendo água de torneira e depositado no recipiente maior. Em cada recipiente eram mantidos quatro a cinco insetos da mesma espécie, escolhidos aleatoriamente conforme eram feitas as coletas no campo. 


\section{Ovos}

\section{Período de incubação}

Para o estudo da duração do período de incubação, ovos foram colocados, logo após a oviposição, em placas de Petri plásticas, medindo nove centímetros de diâmetro por $1,5 \mathrm{~cm}$ de altura, depositados sobre papel filtro, umedecido diariamente com água destilada.

Os ovos que eram depositados sobre as paredes dos recipientes de criação eram destacados com auxílio de um bisturi e depositados diretamente sobre o papel filtro. Os ovos, depositados sobre as folhas que serviam de alimento, eram ali mantidos e a folha destacada e colocada sobre o papel filtro. As placas de Petri com os ovos foram colocadas na estufa Biometron.

Para auxiliar na assepsia foram pingadas três gotas de solução de hipoclorito de sódio $(\mathrm{NaClO})$ a $0,1 \%$, sobre o papel de filtro, antes da colocação dos ovos, segundo recomendação de PARRA (1979). Quando observado o crescimento de fungos no papel de filtro ou sobre os ovos, estes eram lavados com a solução acima citada e transferidos para nova placa.

Para A. punctulata não foi possível determinar a duração do período de incubação dos ovos e nem a duração dos ínstares larvais, pois os adultos encontrados no campo e trazidos para o laboratório, não ovipositaram.

\section{Morfologia}

Nas descrições foram utilizados os ovos de Anacassis fuscata, A. fuscata (forma) e $A$. phaeopoda obtidos em laboratório; para os ovos de A. dubia e A. languida utilizaram-se os poucos ovos obtidos em laboratório e outros, provenientes do campo. Para os ovos de A. punctulata utilizaram-se os coletados no campo.

\section{Mensurações}

Os ovos utilizados nas mensurações (comprimento, maior largura, comprimento do pedúnculo e eixo maior da placa fixadora), foram escolhidos ao acaso. Foram utilizados os ovos obtidos conforme exposto no item anterior (morfologia).

\section{LARVAS}

\section{Número e duração dos ínstares}

Para o estudo do número e duração dos ínstares as larvas foram individualizadas, logo após a eclosão, em pequenos frascos de plástico, cilíndricos, transparentes, medindo $7 \times 4 \mathrm{~cm}$, devidamente fechados com tampa plástica translúcida. As larvas foram colocadas sobre pequeno ramo de sua planta hospedeira com uma ou duas folhas (a mesma planta que servia de alimento aos respectivos adultos da criação estoque) envolto na base por um chumaço de algodão, embebido em água de torneira e colocadas em estufa Biometron, sob temperatura constante. A cada três dias o alimento era trocado.

Eram examinadas diariamente e anotadas as mudas ocorridas e feitas as medidas das cápsulas cefálicas das exúvias que ficam presas nos ramos da furca anal e dali retiradas com auxílio de pinça e estilete. Foi medida a maior largura da 
cápsula cefálica, que fica na altura dos ocelos posteriores, de todos os ínstares larvais.

Para as medições da largura das cápsulas cefálicas das exúvias dos ínstares larvais de $A$. punctulata procedeu-se da seguinte maneira. Das larvas coletadas no campo, retirou-se o anexo exúvio-fecal, que após ser fervido por cerca de quatro minutos em água de torneira, permitiu que as exúvias fossem separadas das fezes.

A largura da cápsula cefálica da larva de quinto ínstar foi medida na própria larva, devido o fato de, na emergência da pupa, a cabeça da larva ficar totalmente danificada.

\section{Morfologia}

Larvas de quinto ínstar foram fixadas em Kahle-Dietrich, para as descrições e fotografias.

Para confecção dos desenhos das cápsulas cefálicas foi necessária sua clarificação e retirada dos músculos, o que foi feito da seguinte maneira: as cabeças, separadas do corpo, foram fervidas em solução de Hidróxido de Potássio $(\mathrm{KOH})$ a $10 \%$, durante cinco minutos. Após, foram fervidas, aproximadamente três a quatro minutos, em água oxigenada (40 volumes) até ficarem suficientemente clarificadas. Em seguida, foram fervidas em água para eliminação das bolhas de ar e colocadas sobre lâmina de vidro, mergulhadas em glicerina e recobertas com lamínula, apoiada em dois suportes, a fim de evitar o esmagamento da cápsula cefálica. As peças bucais (mandíbulas, labro, lábio e maxilas) foram também colocadas sobre uma lâmina de vidro, mergulhadas em glicerina, recobertas com lamínula e, assim, levadas ao microscópio para serem desenhadas.

\section{PUPAS}

\section{Duração do estágio pupal, morfologia e mensurações}

Para estudo da duração do estágio pupal, descrição e mensurações, foram utilizadas as pupas criadas em estufa Biometron.

As pupas de A. dubia, A. fuscata, A. fuscata (forma) e A. phaeopoda foram separadas conforme os sexos e mensuradas. A separação das pupas machos e fềmeas só foi possível ser feita após a emergência dos adultos, cuja identificação dos sexos foi feita pelo exame da genitália. Não foi feita distinção entre machos e fềmeas das pupas de $A$. languida e $A$. punctulata devido o pequeno número de exemplares coletados ou obtidos em laboratório, o que inviabilizaria a obtenção de uma média confiável, no entanto, todas as pupas foram mensuradas.

Pupas de A. dubia, A. languida foram também obtidas de ovos e larvas coletados no campo e mantidos em laboratório. Pupas de A. punctulata foram coletadas no campo e também obtidas em laboratório, de larvas coletadas no campo.

\section{CURVA DE ESPERANÇA DE VIDA E DE SOBREVIVÊNCIA}

Para o estudo da Curva de Esperança de Vida das espécies estudadas, exceto A. punctulata, foram utilizados os imaturos que serviram para o estudo do período de incubação, da duração do período larval e pupal. Quando da realização destes estudos, em laboratório, sempre se acompanhou o destino da coorte inicial, anotan- 
do-se o número de mortos e sobreviventes de cada idade.

Os cálculos relativos à confecção das tabelas de Esperança de Vida e das Curvas de Sobrevivência, bem como os símbolos utilizados e a seguir explicados, são os apresentados por RABINOVICH (1980): (x) idades; (Ix) proporção de sobreviventes na idade $\mathbf{x}$; (dx) número de indivíduos que morrem entre as idades $\mathbf{x}$ e $\mathbf{x}+\mathbf{1}$; (qx) probabilidade de morrer entre $\mathbf{x}$ e $\mathbf{x}+\mathbf{1}$; (Lx) média da probabilidade de sobrevivência entre duas idades sucessivas; (Tx) número total de dias que restam por viver aos sobreviventes que tem alcançado a idade $\mathbf{x} ;(\mathbf{e x})$ Esperança de Vida.

\section{ANÁLISE ESTATÍSTICA}

Foram calculados a média $(\overline{\mathrm{x}})$, o Desvio Padrão (s) e o Coeficiente de Variação (CV) para vários parâmetros, como é exposto a seguir. Ovos: comprimento, maior largura, comprimento do pedúnculo fixador e o maior eixo da placa fixadora; larvas: maior largura das cápsulas cefálicas, duração dos ínstares; pupa: comprimento de machos e fêmeas; duração do período de incubação, larval e pupal.

Calculbu-se a reta de regressão e o coeficiente de correlação entre as variáveis largura média da cápsula cefálica em função dos ínstares larvais e estabeleceu-se a equação da reta.

A comparação das médias entre os parâmetros acima mencionados foi feita através do método de Análise de Variância (ANOVA) para amostras desiguais, segundo modelo proposto por SOKAL \& ROHLF (1981). Os cálculos foram feitos através do uso de microcomputador, utilizando programa desenvolvido pelo Prof. Dr. Pe. Jesus S. Moure e Dr. J.R. Cure (ANOTSG.BIO e TATMED.TAX) em que os limites de confiança foram estabelecidos pelo método de aproximação simples de Gabriel, sempre ao nível de $\mathrm{P}=0,05$.

A comparação estatística das Curvas de Sobrevivência foi feita através do Método G, citado por RABINOvich (1980), sempre ao nível de $\mathrm{P}=0,05$.

Os conceitos estatísticos, a terminologia utilizada e os cálculos, além dos autores citados acima, foram sempre de acordo com SPIEgEL (1972) e VIEIRA (1981).

\section{RESULTADOS E DISCUSSÃO}

\section{MORFOLOGIA}

Anacassis dubia (Boheman, 1854)

Figs $1,7,13-15,26,32,38,44,50,56-58,74,80,85$

\section{Ovo}

Aproximadamente duas vezes mais longo que sua maior largura; comprimento médio, 1,82 $\mathrm{mm}$ (amplitude: 1,64 a 1,92mm; s: 0,0908); largura média, 0,78mm (amplitude: 0,73 a 0,82mm; s: 0,0285) (Tabs I-II, Fig. 7); ocre; subcilíndrico; superfície densamente pontuada e no meio mais largo. Nas duas extremidades com pequena micrópila arredondada; a anterior que sempre fica oposta ao substrato, recoberta com substância acastanhada; a posterior com a membrana vitelínica 
visível. Em geral, fixos ao substrato através de curto pedúnculo, subcilíndrico, acastanhado, preso na extremidade látero-posterior e no ápice, alargado em fina placa, subcircular e translúcida. O comprimento médio do pedúnculo, $0,70 \mathrm{~mm}$ (amplitude: 0,33 a 1,30mm; s: 0,3098) e o maior eixo da placa fixadora, em média 0,85mm (amplitude: 0,65 a 1,17mm; s: 0,1473) (Tabs III-IV).

Os ovos são postos em grupos (Fig. 7), formando duas ou mais fileiras, mais ou menos evidentes, quase todos num mesmo plano, com um número médio de 9,17 ovos por postura (amplitude: 7 a 10 ovos; s: 1,3229) (Tab. V), em posição quase vertical, colados uns aos outros, lateralmente, na altura do meio.

\section{Larva de quinto ínstar}

Pouco mais longa que duas vezes sua maior largura; dorsoventralmente pouco achatada (Figs 14-15); lados subparalelos, convergindo levemente para frente e fortemente para trás a partir do sexto tergo.

Aos lados com 14 pares de escolos, subiguais em comprimento (com as seguintes mensurações, em milímetros, numa larva de quinto ínstar: 1,$33 ; 1,33 ; 1,83$; $1,75 ; 2,17 ; 2,08 ; 1,67 ; 1,58 ; 1,33 ; 1,25 ; 1,25 ; 2,00 ; 2,50 ; 2.92)$ assim dispostos: três pares no protórax, dois no mesotórax; um no metatórax e um par em cada um dos oito segmentos abdominais. O oitavo segmento com furca anal, cujos ramos alcançam o quinto tergo, quando voltados para a frente (aproximadamente $2,10 \mathrm{~mm}$ de comprimento).

Cabeça subarredondada, em vista frontal (Fig. 26); de lado, um pouco achatada. Os parietais cerca de 1,5 vezes mais longos que largos; com forte depressão no meio, na altura das antenas, logo atrás do clípeo. Largura média da cápsula cefálica, 1,54mm (amplitude: 1,44 a 1,68mm; s: 0,0767) (Tab. VII).

Antenas com o primeiro artículo anelar e o segundo, subcônico com alguns processos sensoriais apicais. Ocelos, em número de seis, sobre pequenos tubérculos, dispostos aos pares, logo atrás das antenas; o ocelo mais externo e anterior, voltado para frente. Clípeo cerca de 2,5 vezes mais largo que seu comprimento ao longo do meio, margem posterior com forte projeção mediana, os lados convergindo para frente, margem anterior, reta. Labro aproximadamente 2,5 vezes mais largo que seu comprimento mediano (Fig. 38), margem posterior levemente bissinuada e aos lados com curto apódema, margem anterior com forte chanfro no meio. Mandíbulas no ápice com cinco dentes (Fig. 44), cujos bordos são crenulados. Maxilas com o cardo alongado (Fig. 32); estipe quase tão longo quanto os palpos e prolongado, no lado interno, com a mala globosa; palpo com dois artículos, subiguais em comprimento, o apical, subcônico e o basal anelar. Lábio com área do mento e submento membranosa e alargada pra trás; estipe anteriormente membranosa e posteriormente esclerotinizada; palpos uniarticulados, subcônicos e no ápice com alguns processos sensoriais.

Placa pronotal dividida ao meio por suave sulco, superfície com sulcos irregulares, margem anterior levemente arqueada e a posterior, suavemente sinuada no meio.

Meso- e metanoto, semelhantes, em torno de seis vezes mais largos que longos; divididos por sulco transversal em pré- e postergitos; o mesonoto, látero- 
anteriormente, com projeção onde está o espiráculo mesotorácico e o quarto par de escolos.

Tergos torácicos e abdominais divididos em pré- e postergitos, por sulco mediano transversal, que no tórax não alcança as margens laterais e no abdômen não alcançam a linha dos espiráculos. Do primeiro ao oitavo tergo abdominal, cada um com um par de espiráculos, próximos à base dos escolos, os anteriores com peritreme maior e diminuindo gradativamente para trás; o último, muito atrofiado.

Pernas com fêmur e tíbia de comprimentos iguais, tarsúngulo com dente laminar (Fig. 50).

Esternos abdominais muito alargados e estreitos; o segundo cerca de 5,5 mais largo que seu comprimento médiano; os demais semelhantes, porém, a partir do quinto, estreitados para trás; o nono e décimo, formando o tubo anal.

Coloração. Tegumento amarelo-esbranquiçado, exceto as seguintes partes, pretas: escolos e furca anal, exceto próximo à base, peritrema, faixa posterior e transversal do oitavo tergo abdominal, logo à frente da furca anal, a cabeça que apresenta partes pretas, acinzentadas e intermediárias; pernas com manchas pretas na base e ápice do fêmur e tíbia, maiores na tíbia. No lado interno da linha dos espiráculos, às vezes, com manchas subretangulares, acinzentadas, formando em conjunto uma faixa alongada.

Pilosidade.Dorsalmente com tegumento glabro. No lado ventral com poucas cerdas no meio dos esternos torácicos, pernas com cerdas em maior número no lado dorsal e ápice da tíbia, muitas cerdas nos seis primeiros esternos abdominais e muito poucas nos demais. Os escolos com cerdas fortes e eretas, mais numerosas na base.

\section{Larva de quarto ínstar}

Morfologicamente a larva de quarto ínstar é semelhante à larva de quinto ínstar, embora de tamanho menor. As diferenças estão relacionadas com a coloração (Fig. 13). Tegumento de mesma coloração da larva de quinto ínstar: amarelo-esbranquiçado, escolos totalmente pretos, cabeça enegrecida com cinco manchas amarelas no epicrânio: uma ao longo da sutura coronal, duas à frente dos ocelos e ao lado interno da antena e duas, aos lados, próximo à base das mandíbulas; placa pronotal enegrecida em parte; pretergito do mesonoto com quatro manchas pretas, subarredondadas, em fileira transversal, duas a cada lado da linha média longitudinal e o postergito, com quatro manchas em fileira transversal, as duas internas mais próximas entre si que as demais; pré- e postergito do metanoto, semelhantes aos do mesonoto; látero-anteriormente, próximo à base do quinto e sexto pares de escolos com duas manchas pretas; pernas enegrecidas. Abdômen: pretergitos com três manchas pretas em cada metade, exceto o primeiro tergo com quatro, dispostas em fileira transversal, a mancha mais externa, próxima ao espiráculo e a mais interna, próxima à linha mediana; postergitos com duas manchas pretas em cada metade, dispostas em fileira transversal e intercaladas com as duas manchas mais internas dos pretergitos; em conjunto, formam cinco fileiras longitudinais, mais ou menos evidentes. 


\section{Pupa}

Corpo alongado, cerca de 1,8 vezes mais longo que sua maior largura (Figs 56-58). Em vista de perfil, dorsalmente convexa, mais fortemente no ápice do abdômen, a partir do quinto tergo; ventralmente aplanada. Vista de cima, os lados (exceto os do pronoto) largamente arredondados para trás a partir do terceiro tergo e fracamente para frente até o pronoto, a partir do primeiro tergo. No sentido transversal, dorsalmente, levemente convexa, mais fortemente do sexto tergo até o ápice do abdômen.

Superfície com microcanalículos, irregularmente dispostos; com predominância transversal no abdômen.

O comprimento médio da pupa, macho e fềmea (Tab. XV), é $7,34 \mathrm{~mm}$ (amplitude: 6,92 a 7,67mm; s: 0,2922) e 8,34mm (amplitude: 7,58 a 9,67mm; s: $0,6258)$, respectivamente.

Pronoto cerca de duas vezes mais largo que seu comprimento mediano, área discal mais elevada que as abas, estas rebaixadas somente aos lados, margem anterior curtamente arredondada, com pequeno chanfro no meio, os lados largamente arredondados e mais para frente convergentes, margem posterior com forte projeção mediana, com suave sulco ao longo do meio.

Mesonoto com área do escutelo saliente; margem posterior com forte projeção mediana e para os lados fortemente côncava. Élitros voltados para o lado ventral e o ápice alcançando o quinto esterno abdominal. Metanoto, no meio pouco mais longo que o mesonoto, margem anterior fortemente bilobada, margem posterior fracamente bissinuada; projeção mediana posterior levemente projetada e dorsalmente com pequena projeção.

Abdômen com o primeiro tergo cerca de 7,5 vezes mais largo que longo (excluídos os escolos); os tergos dois a cinco semelhantes ao primeiro; os tergos quatro e cinco, pouco mais estreitados; do sexto tergo ao último, estreitados rapidamente em direção ao ápice; o oitavo tergo cerca de 3,7 vezes mais largo anteriormente que seu comprimento mediano.

Aos lados, com oito pares de escolos, um par por segmento; os cinco anteriores, voltados para fora e para frente e diminuindo gradativamente de tamanho do primeiro ao quinto (medidas do comprimento dos escolos, feitas numa pupa, com os seguintes resultados, em milímetros: 1,$08 ; 0,92 ; 0,75 ; 0,67 ; 0,58 ; 0,68 ; 0,68$; 0,40 ); o sexto e sétimo pares de escolos de mesmo comprimento, pouco mais longos que o quinto par, voltados para trás; o oitavo, mais ventral e o mais curto de todos; o primeiro par tão largo na base quanto o tergo correspondente; os demais mais estreitos na base.

Aos lados, dorsalmente, próximo à base dos escolos, os espiráculos, um par por segmento, do primeiro ao quinto tergo; o anterior com peritrema e óstio maior que os demais que diminuem gradativamente de tamanho.

Entre a linha dos espiráculos e a linha mediana dorsal, uma fileira de pequenas depressões, que diminuem de tamanho para trás, até o sétimo tergo e em conjunto tem aspecto de sulco longitudinal suave.

Cabeça, em vista ventral, cerca de duas vezes mais longa que larga; ao longo 
do meio com suave sulco; no vértice com dois curtos lobos, achatados no sentido transversal. Antenas voltadas para trás e para fora; o ápice alcançando a articulação fêmur-tibial anterior. Área clípeo-labral, em forma de losango, cerca de duas vezes mais larga que seu comprimento mediano; com suave e largo sulco do meio até o ápice. Mandíbulas, em concha, cerca de duas vezes mais longas que largas; face externa fortemente convexa. Palpos digitiformes; os maxilares pouco mais longos que os labiais.

Perna anterior com fêmur e tíbia quase de mesmo comprimento e achatados de encontro ao corpo; tarsos com segmentação pouco evidente. Pernas média e posterior semelhantes à anterior; a posterior com o fêmur e tíbia recobertos pelos élitros, exceto o ápice da articulação fêmur-tibial e o tarso.

Esternos do abdômen curtos e alargados; no último a abertura anal e a furca, com curtos ramos, voltados para trás e para fora e bastante afastados na base.

Coloração. Amarelo pálida. As seguintes partes pretas: margem posterior do pronoto e ao longo do meio, com duas faixas separadas por sulco mediano; margem posterior dos élitros com larga faixa, que se inicia na base e termina na altura do quarto esterno; dois terços do escolo anterior e nos demais diminuindo até o quinto; primeiro tergo com faixa transversal próxima à margem anterior, com pequeno chanfro no meio, quase alcançando o espiráculo anterior aos lados; ao longo do meio, do primeiro ao sexto tergo, estreita faixa, bem marcada, de lados paralelos, interrompida na altura das articulações inter-tergais; ao longo da linha dos espiráculos, junto à margem posterior dos tergos dois a cinco, com manchas pequenas e arredondadas, mais fortes nos tergos três e quatro.

Lados dos tergos um a sete, abrangendo os espiráculos e parte basal dos cinco escolos anteriores, com faixa castanho-avermelhada bem marcada (na foto de cor acinzentada); mesonoto e metanoto, com pequena mancha castanho-avermelhada aos lados, subtriangular, sendo maior a do mesonoto.

Pilosidade. Muito escassa, irregularmente distribuída, esbranquiçada e inconspícua. Glabros os escolos seis a oito, furca anal, élitros e antenas.

\section{Anacassis fuscata (Klug, 1829)}

Figs $2,8,16-19,27,33,39,45,51,59-61,75,81,86$

Dois fenótipos distintos de $A$. fuscata, antes considerados subespécies distintas embora ocorrendo simpatricamente em Curitiba, foram estudados: A. fuscata (Klug, 1829) e A. fuscata [forma=unicolor (Burmeister, 1870)]. O estudo mostrou que as diferenças não foram significativas (vide conclusões).

\section{Ovo}

Aproximadamente 2,4 vezes mais longo que sua maior largura; comprimento médio 1,68mm (amplitude: 1,58 a 1,76mm; s: 0,0492) e largura média 0,71 mm (amplitude: 0,60 a 0,78mm; s: 0,0470) (Tabs I-II); ocre; subcilíndrico; no meio mais largo; densamente pontuado (Fig. 8). Com pequena micrópila arredondada em cada extremidade; a anterior, oposta ao substrato, recoberta com substância acastanhada; a posterior, não recoberta, deixando ver a membrana vitelina. Fixos ao substrato 
através de pequeno pedúnculo, subcilíndrico, acastanhado, preso na extremidade látero-posterior e no ápice alargado em fina placa, subcircular e translúcida. $\mathrm{O}$ comprimento médio do pedúnculo é $0,14 \mathrm{~mm}$ (amplitude: 0,02 a 0,26 mm; $\mathrm{s}: 0,0764$ ) e o comprimento médio do maior eixo da placa fixadora é $0,76 \mathrm{~mm}$ (amplitude: 0,66 a $0,86 \mathrm{~mm}$; s: 0,0665 ) (Tabs III-IV).

Os ovos são postos em grupos (Fig. 8), formando duas ou mais fileiras, mais ou menos evidentes, quase todos num mesmo plano, com um número médio de 12,54 ovos por postura (amplitude: 5 a 18 ovos; s: 3,6882), em posição quase sempre vertical, colados uns aos outros, lateralmente, próximo à altura do meio. (Tab. V).

\section{Larva de quinto ínstar}

Aproximadamente duas vezes mais longa que sua maior largura, (Figs 16-17) dorso-ventralmente pouco achatada, os lados subparalelos, convergindo suavemente para frente a partir do metatórax e fortemente para o ápice a partir do sexto tergo. Aos lados com 14 pares de escolos subiguais em comprimento (com as seguintes mensurações numa larva de quinto ínstar, em milímetros: 1,$08 ; 1,16 ; 1,20 ; 1,00$; $1,68 ; 1,60 ; 1,24 ; 1,20 ; 1,20 ; 1,16 ; 1,20 ; 1,76 ; 1,60 ; 1,88)$ assim dispostos: três pares no protórax, dois no mesotoráx, um no metatoráx e oito abdominais, do primeiro ao oitavo tergo, este dorsalmente, com a furca anal, cujos ramos alcançam o quinto tergo, quando voltados para frente (aproximadamente $1,80 \mathrm{~mm}$ de comprimento).

Cabeça subarredondada, em vista frontal; de lado, pouco achatada (Fig. 27). Os parietais, pouco mais longos que largos; no meio, na altura das antenas, logo atrás do clípeo, com larga e suave depressão. Largura média da cápsula cefálica é igual a 1,58mm (amplitude: 1,50 a 1,73mm; s: 0,0636) (Tab. VIII).

Antenas com dois artículos; o basal, reduzido a um curto anel e o distal, alongado, aproximadamente 1,5 vezes mais longo que sua larguara basal; ápice com alguns processos sensoriais, geralmente em número de cinco, destacando-se um, maior. Ocelos, em número de seis a cada lado, dispostos aos pares, sobre pequenos tubérculos; o mais anterior voltado para frente. Clípeo, cerca de 2,5 vezes mais largo que seu comprimento mediano; margem posterior com forte projeção no meio; os lados convergindo para frente; margem anterior reta. Labro aproximadamente 2,5 vezes mais largo que seu comprimento mediano (Fig. 39); margem posterior levemente bissinuada e aos lados com curto apódema; margem anterior com suave chanfro no meio. Mandíbulas no ápice com cinco dentes de margens crenuladas (Fig. 45). Maxilas com o cardo alongado (Fig. 33), no lado interno pouco mais longo que o palpo maxilar e o estípe juntos; este, no lado externo, quase tão longo quanto os dois artículos do palpo maxilar e no lado interno continua-se com a mala globosa; palpo maxilar biarticulado, o artículo basal subcilíndrico e o distal, subcônico, com alguns processos sensoriais apicais. Lábio com área do mento e submento membranosa e alargada suavemente para trás; estipe anteriormente membranosa e posteriormente esclerotinizada; palpos uniarticulados, subcônicos, no ápice com alguns processos sensoriais.

Placa pronotal anteriormente reta, posteriormente, no meio com forte chanfro; superfície com alguns sulcos e numerosas chalazas, esparsamente distribuídas, mais abundantes na metade posterior; ao longo do meio sulcada. Mesonoto cerca 
de cinco vezes mais largo que seu comprimento mediano (excluídos os escolos); o premesotergito com um par de chalazas a cada lado da linha mediana, dispostas em linha transversal; postmesotergito látero-anteriormente com algumas chalazas (em torno de quatro), próximas à base do quinto par de escolos, no meio com três, as vezes duas, chalazas em fileira transversal e entre estas e o escolo, um par de chalazas muito próximas entre si; látero-anteriormente com forte projeção onde se situa o primeiro par de espiráculos e ao lado, o quarto par de escolos. Metanoto semelhante ao mesonoto porém sem a projeção látero-anterior. Abdômen com os sete primeiros tergos divididos em pré- e postergitos, por sulco transversal, voltado para trás pouco antes da linha dos espiráculos; os pretergitos com três a quatro chalazas e os postergitos, com uma a três chalazas, geralmente três, dispostas em fileira transversal; no sentido longitudinal as chalazas do abdômen, formam cinco fileiras mais ou menos evidentes. Aos lados do primeiro ao sétimo tergo os espiráculos, um par por segmento, com peritrema bem saliente que diminuem de tamanho gradativamente, do primeiro ao último; este muito atrofiado. Esternos torácicos lisos; o prosterno pouco menor que o mesosterno; este quase igual ao metasterno. Perna com a tíbia pouco mais curta que o fêmur, tarsúngulo apical com pequeno dente laminar na base (Fig. 51). Esternos abdominais muito alargados e estreitos; o segundo cerca de 5,5 vezes mais largo que seu comprimento médiano; os demais semelhantes, porém, a partir do quinto, estreitado para trás; o nono e décimo formando tubo anal que no lado ventral é esclerotinizado, dividido ao meio por faixa esbranquiçada.

Coloração. Amarela. Pretas as seguintes partes: cabeça, escudo pronotal,terços laterais do meso e metanoto, aos lados dos tergos do abdômen e ao longo do meio com manchas acinzentadas muito fracas, às vezes, quase imperceptíveis, chalazas, peritremas, escolos, às vezes, amarelados no terço médio), partes esclerotinizadas das pernas, os lados dos esternos torácicos e abdominais, que, às vezes, tem coloração quase totalmente amarela; os três últimos esternos, às vezes, quase totalmente pretos.

Pilosidade. Cabeça com cerdas presentes a partir da altura do ocelo mais posterior para frente, mais abundantes em volta dos ocelos; tórax e abdômen com cerdas no ápice das chalazas, mais abundantes ventralmente; escolos com numerosas cerdas. Tarsúngulo com cerda na base do dente lamelar (Fig. 51).

\section{Pupa}

Corpo pouco alongado, cerca de 1,6 vezes mais longo que sua maior largura, exluídos os escolos (Figs 59-61). Em vista de perfil, dorsalmente convexa, mais fortemente no ápice do abdômen a partir do quinto tergo; ventralmente aplanada. Vista de cima, os lados (exceto os do pronoto) levemente convexos, mais fortemente no ápice do abdômen, a partir do sexto tergo. No sentido transversal, dorsalmente, levemente convexa, mais fortemente do sexto tergo até o ápice do abdômen.

O comprimento médio das pupas, macho e fêmea, é respectivamente igual a 7,57mm (amplitude: 7,08 a 8,33mm; s: 0,3361) e 8,43mm (amplitude: 8,25 a $8,83 \mathrm{~mm} ; \mathrm{s:}$ 0,2121) (Tab. XV).

Pronoto cerca de duas vezes mais largo que seu comprimento mediano; área discal mais elevada que as abas, aos lados; margem anterior largamente arredonda- 
da, no meio com pequeno chanfro; margens laterais fortemente convexas; margem posterior com forte projeção mediana; superfície com micro canalículos irregularmente dispostos; ao longo do meio com suave sulco; próximo ao meio de cada metade da área discal, com uma ou duas irregulares e suaves depressões.

Mesonoto: a margem posterior com forte projeção mediana que para os lados é fortemente côncava. Élitros voltados para trás e ventralmente alcançando o quinto esterno abdominal.

Metanoto, no meio, pouco mais longo que o mesonoto; margem posterior quase reta com suave e larga projeção mediana; margem anterior, aos lados, com forte lobo; juntamente com o primeiro tergo abdominal, no sentido transversal, pouco mais projetado tomando aspecto de pequena elevação.

Abdômen, dorsalmente, com superfície semelhante a do pronoto; primeiro tergo, aproximadamente 7,8 vezes mais largo que seu comprimento mediano (excluídos os escolos); os tergos dois a cinco, semelhantes ao primeiro, porém estreitados levemente para trás; do sexto ao último, pouco mais largos no meio que os anteriores e estreitados rapidamente em direção ao ápice. Aos lados, com oito pares de escolos, um par por segmento; os cinco anteriores, voltados para fora e para frente e diminuindo gradativamente de tamanho, do primeiro ao oitavo par (com as seguintes mensurações numa pupa, em milímetros: 1,$00 ; 0,88 ; 0,72 ; 0,68 ; 0,60$; $0,58 ; 0,50 ; 0,42)$; o primeiro par, tão largo na base quanto o primeiro tergo; os demais, mais estreitos que os tergos correspondentes; o sexto e sétimo pares, voltados para trás; o oitavo par, fixo mais ventralmente no oitavo esterno e voltado para o meio. Aos lados, dorsalmente, próximo à base dos escolos, os espiráculos, um par por segmento, do primeiro ao sexto tergo; o anterior com peritrema maior que os demais que deminuem gradativamente de tamanho. Entre a linha dos espiráculos e a linha mediana dorsal, um fileira de pequenas depressões, que diminuem de tamanho para trás.

Cabeça, em vista ventral, cerca de duas vezes mais longa que larga; ao longo do meio com suave sulco; no ápice com dois lobos, achatados no sentido transversal. Antenas voltadas para trás e para fora; ápice alcançando a articulação fêmur-tibial anterior; segmentação pouco evidente; em cada artículo, no lado mais ventral, com curto processo cônico, que aumentam de tamanho, do anterior ao mais posterior. Área clípeo-labral em forma de losango, cerca de duas vezes mais larga que seu comprimento mediano. Mandíbulas em concha, cerca de duas vezes mais longas que largas; face externa, fortemente convexa. Palpos labiais digitiformes, curtos; os maxilares, cerca de duas vezes mais longos que os labiais.

Perna anterior com o fêmur e tíbia, quase de mesmo comprimento e achatados de encontro ao corpo; tarsos com segmentação pouco evidente. Perna média de mesmo aspecto que a anterior e a posterior, semelhante à anterior, recoberta pelos élitros, exceto o ápice da articulação fêmur-tibial e o tarso.

Esternos abdominais curtos e alargados; no último a abertura anal e a furca, com curtos ramos, voltados para trás e para fora.

Coloração. Corpo amarelo-pálido. Pretas as seguintes partes: margem posterior do pronoto; mesonoto quase totalmente; élitros na base e na margem posterior 
com faixa que termina na margem externa; palpos maxilares e labiais; antenas; escolo anterior totalmente e do segundo ao quarto apicalmente; abdômen, ao longo do meio, com faixa do primeiro ao quinto tergo, às vezes, até o sexto, que se prolonga para os lados nos tergos três, quatro e cinco; no tergo três, às vezes, não se prolonga para os lados ou muito pouco, e, às vezes, alcança a base do terceiro escolo.

Acinzentadas as seguintes partes: pronoto com duas estreitas faixas ao longo do meio, separadas pelo sulco mediano e em cada metade, com mancha irregular; élitros com duas faixas, a mais anterior, mais curta, alcança a articulação fêmur-tibial média e a posterior, termina próximo ao ápice do élitro, às vezes, com quarta faixa mais anterior e mais curta que as demais; cabeça e pernas (fêmur, tíbia e tarso); tergo anterior do abdômen quase totalmente; em volta dos espiráculos, exceto o anterior, com mancha arredondada, muito fraca e inconspícua no último.

Pilosidade. Na cabeça, pernas, esternos abdominais e no lado dorsal, com cerdas muito curtas, $0,08 \mathrm{~mm}$ de comprimento, esbranquiçadas e muito esparsas. Os cinco pares anteriores de escolos com chalazas curtas e esparsas. O três pares posteriores de escolos e furca anal, glabros.

\section{Anacassis fuscata [(forma=unicolor (Burmeister, 1870)]}

Figs $4,9,18,19,28,34,40,46,52,62-64,76,82,87$

\section{Ovo}

Morfologicamente semelhante ao de A.fuscata com exceção das medidas que apresentam pequenas diferenças não significativas (Fig. 9). O comprimento médio é $1,72 \mathrm{~mm}$ (amplitude: 1,66 a 1,78; s: 0,0282) e a largura média é $0,74 \mathrm{~mm}$ (amplitude: 0,68 a 0,$94 ; \mathrm{s:}$ 0,0672) (Tabs I-II). O comprimento médio do pedúnculo é igual a $0,37 \mathrm{~mm}$ (amplitude: 0,20 a 0,60 mm; s: 0,1135) e o comprimento médio do eixo maior da placa fixadora é $0,78 \mathrm{~mm}$ (amplitude: 0,60 a $0,90 \mathrm{~mm}$; s: 0,0870) (Tabs III-IV).

Os ovos de A.fuscata (forma) são postos em grupos de modo semelhante aos de A.fuscata, com um número médio de 14,29 ovos por postura (amplitude: 8 a 18 ovos; s: 2,6144) (Tab. V).

\section{Larva de quinto ínstar}

Morfologicamente a larva de quinto ínstar (Figs 18-19) é semelhante à larva de quinto ínstar de A. fuscata. A maior largura média, em milímetros, da cápsula cefálica é 1,54 (amplitude: 1,50 a 1,73; s: 0,0779) (Tab. IX). Cabeça semelhante a de A. fuscata assim como as peças bucais (Figs 28, 34, 40, 46). Tórax e abdômen semelhantes aos de $A$. fuscata. A coloração do tórax e do abdômen é mais amarelo-esbranquiçada. A distribuição das chalazas do tórax e do abdômen é semelhante a de $A$. fuscata.

\section{Pupa}

Morfologicamente a pupa (Figs 62-64) é semelhante à de A.fuscata; pequenas diferenças aparecem na coloração, apresentadas na Discussão (página 74). A pupa macho mede em média 7,37mm de comprimento (amplitude: 6,17 a 8,00 mm; 
s: 0,1052). A pupa fêmea mede, em média, $8,07 \mathrm{~mm}$ de comprimento (amplitude: 7,33 a $8,75 \mathrm{~mm}$; s: 0,3559) (Tab. XV).

Anacassis languida (Boheman, 1854)

Figs $3,10,20,21,29,35,41,47,53,65-67,77,83,88$

\section{Ovo}

BUZZI \& GARCIA (1983) descreveram o ovo de A. languida, transcrita a seguir. "Aproximadamente 2,3 vezes mais longo que seu maior diâmetro, oval, oblongo (comprimento médio 2,03mm; maior diâmetro: 0,90mm)" (Fig. 10); “acastanhado, córion pontuado. Em ambas as extremidades, com micrópila arredondada; a anterior recoberta com substância acastanhada".

As mensurações, feitas na presente pesquisa, apresentaram os seguintes resultados: O comprimento médio é igual a 2,03mm (amplitude: 1,92 a 2,12mm; $\mathrm{s}$ : 0,0700 ); a largura média é igual a $0,90 \mathrm{~mm}$ (amplitude: 0,82 a $0,96 \mathrm{~mm} ; \mathrm{s}: 0,0398$ ) (Tabs I-II). Fixos ao substrato, geralmente através de pequeno pedúnculo, subcilíndrico, acastanhado, preso na extremidade látero-posterior e no ápice, alargado em fina placa fixadora, subcircular e translúcida.

O comprimento médio do pedúnculo e do eixo maior da placa fixadora, é igual a $0,81 \mathrm{~mm}$ (amplitude: 0,90 e 1,52 mm; s: 0,4366) e 0,90mm (amplitude: 0,48 e $1,25 \mathrm{~mm}$; s: 0,2860), respectivamente (Tabs III-IV).

Segundo BUZZI \& GARCIA (1983) "Os ovos são postos em grupos, com no máximo 18 ovos (média de 6,7 ovos), na face superior da folha e ficam presos às folhas através do pedúnculo ou diretamente" (Fig. 10).

\section{Larva de quinto ínstar}

BUZZI \& GARCIA (1983) descreveram a larva de quinto ínstar, transcrita a seguir, em português: "Dorso-ventralmente muito achatada; os lados subparalelos com 14 pares de escolos (Figs 20-21): três no protórax, dois no mesotórax, um no metatórax e um em cada segmento abdominal; subiguais em comprimento (com as seguintes medidas, numa larva de quinto ínstar, do primeiro ao $14^{\circ}$ par: 1,$10 ; 0,96$; $1,70 ; 1,36 ; 1,76 ; 1,64 ; 1,58 ; 1,48 ; 1,44 ; 1,48 ; 1,50 ; 1,90 ; 2,30 ; 2,20)$. O oitavo segmento abdominal com furca anal com $1,6 \mathrm{~mm}$ de comprimento. Aos lados com nove pares de espiráculos, o primeiro par no mesotórax, cada segmento abdominal com um par, o último atrofiado, peritremas anteriores mais salientes. Pró-, meso- e metatórax com suave sulco ao longo do meio. Cabeça opistognata, em vista frontal subcircular (Fig. 29); parietais 1,5 vezes mais longos do que largos. Próximo à sutura epicranial, ao nível do ocelo médio, com depressão a cada lado. A largura média da cápsula cefálica, é igual a 1,83mm (amplitude: 1,70 a 1,99mm; s: 0,1053) (Tab. X). Seis pares de ocelos, o anterior localizado aos lados e atrás da antena. Esta unisegmentada, quase tão longa quanto seu diâmetro, no ápice com vários processos sensoriais, sendo um maior. Clípeo aproximadamente 2,3 vezes mais largo que seu comprimento mediano, a margem anterior levemente sinuada, margens laterais convergindo fortemente para frente. Labro aproximadamente duas vezes mais largo que longo (Fig. 41), margem anterior levemente sinuada, os lados arredondados, 
margem posterior em arco e com curto apódema aos lados. Mandíbulas em concha, no ápice com cinco dentes, na base com côndilo. Maxilas com o cardo alongado (Fig. 47); palpo com dois segmentos, o basal anelar e o distal, cônico com vários processos sensoriais no ápice; estipe pouco mais longa do que o palpo; mala globosa. Lábio com palpo cônico, unisegmentado com vários processos sensoriais apicais (Fig. 35); estipe com faixa transversal esclerotinizada, área do mento e submento fusionadas e levemente alargada para trás. Pernas normais, com pequeno epímero sobre a coxa e pequeno tarsúngulo no ápice da tíbia (Fig. 53).

Amarelada, as seguintes partes pretas: parietais, terço posterior do clípeo; partes esclerotinizadas das peças bucais e pernas; partes laterais do tórax e abdômen; terceiro esterno abdominal em parte e do quarto para trás totalmente; escolos e furca anal; pro-, meso- e metanoto exceto ao longo da linha mediana longitudinal e algumas manchas próximas aos sulcos transversais; três fileiras de manchas, nos tergos abdominais, as fileiras laterais com manchas arredondadas, as anteriores menores, a fileira central com manchas alongadas distintas, até o sexto tergo; chalazas dorsais.

Os parietais com muitas cerdas de diferentes tamanhos, as mais longas, próximas aos ocelos e antenas, com $0,6 \mathrm{~mm}$ de comprimento. Peças bucais com pequenas e esparsas cerdas. Dorsalmente com pequenas e inconspícuas chalazas. Ventralmente, com inúmeras cerdas, aos lados e posteriormente, com cerdas curtas, medindo em média $0,10 \mathrm{~mm}$; esternos torácicos e os cinco primeiros esternos abdominais com cerdas mais abundantes e medindo em média $0,20 \mathrm{~mm}$ de comprimento".

\section{Pupa}

BUZZI \& GARCIA (1983) descreveram a pupa de $A$. languida que é transcrita a seguir em português: "Oval, alongada, dorsalmente convexa e ventralmente aplanada. (Figs 65-67).

O comprimento médio da pupa é igual a 9,52mm (amplitude: 9,40 a 9,70 mm; s: 0,1304) (Tab. XVI).

Pronoto 1,6 vezes mais largo que seu comprimento médio (largura: 5,52mm; comprimento: $3,52 \mathrm{~mm}$ ); margem anterior arredondada com duas pequenas, cônicas e inconspícuas projeções a cada lado; margens laterais fortemente arqueadas; margem posterior com pequena projeção mediana; dorsalmente ao longo do meio com suave sulco e a cada lado com suave depressão. Mesonoto na base mais estreito que o pronoto, com suave sulco mediano longitudinal, estendendo-se até o escutelo, muito saliente. Metanoto com sulco mediano longitudinal que se estende até o meio. Primeiros quatro tergos abdominais, cerca de sete vezes mais largos que longos; os últimos quatro tergos progressivamente mais estreitados. Cada segmento abdominal com escolos aos lados; os primeiros cinco pares de escolos visíveis quando a pupa está presa na exúvia da larva do último ínstar; os primeiros seis pares de escolos voltados para frente, o par anterior mais fortemente voltado para frente; sétimo e oitavo pares muito curtos e voltados para trás. No oitavo segmento abdominal a furca anal muito curta $(0,25 \mathrm{~mm}$ de comprimento). Sete pares de espiráculos, um par por segmento abdominal, situados dorsalmente, próximo à base dos escolos; os 
primeiros cinco pares com peritrema mais saliente nos anteriores e diminuindo progressivamente para trás; sexto e sétimo pares muito atrofiados. Cabeça com vértice fracamente bilobado. Clípeo aproximadamente cinco vezes mais largo que longo. Labro suborbicular, margem anterior fortemente sinuada e a posterior, fracamente. Mandíbulas em concha com três pequenas projeções no ápice.

Palpos maxilares com três segmentos, um pouco mais longos que seu maior diâmetro. Mala globosa. Palpos labiais unisegmentados um pouco mais longos que seu maior diâmetro. Antena voltada para trás e para fora, $o$ ápice alcançando o fêmur anterior. Pernas achatadas, a anterior e a média totalmente visíveis e a posterior parcialmente recoberta pelas asas e só visível os tarsos e ápice da articulação fêmur-tibial. Segmentos abdominais mais estreitos no meio e pouco, aos lados.

Amarelada, as seguintes partes pretas: parte central do pronoto com um par de manchas, às vezes, unidas à faixa mediana; margem posterior e base dos élitros; área escutelar; tergos abdominais com cinco fileiras de manchas, a lateral correspondendo ao peritrema dos espiráculos, as duas intermediárias com início no metanoto e estendendo-se até o sexto tergo, com manchas arredondadas e subiguais, a central, com manchas alongadas e se inicia fracamente no metanoto e se torna mais escura do segundo ao sexto tergo abdominal; os primeiros cinco pares de escolos quase totalmente; antenas e peças bucais. Tarsos e margem externa do fêmur anterior, margem externa e apical do fêmur médio e ápice do fêmur posterior com coloração mais acinzentada".

Anacassis phaeopoda Buzzi, 1976

Figs $5,11,22,23,30,36,42,48,54,68-70,78,84,89$

\section{Ovo}

Aproximadamente 2,2 vezes mais longo que sua maior largura; comprimento médio igual a $1,78 \mathrm{~mm}$ (amplitude: 1,60 a 1,94mm; s: 0,0755) e largura média igual a $0,82 \mathrm{~mm}$ (amplitude: 0,74 a $0,86 \mathrm{~mm}$; s: 0,0326 ) (Tabs I-II; Fig. 11); ocre; subcilíndrico; no meio mais largo; superfície densamente pontuada. Nas duas extremidades com pequena micrópila arredondada; a anterior, que sempre fica oposta ao substrato, recoberta com fina camada de substância acastanhada, às vezes, translúcida que permite ver os contornos da micrópila; a posterior, não recoberta e com a membrana vitelínica visível. Fixos aos substrato pelo polo posterior através da placa fixadora e muitas vezes, apresentam látero-posteriormente, um pequeno pedúnculo que se alarga no ápice em fina placa fixadora, em geral subarredondada e translúcida. O comprimento médio do pedúnculo é igual a $0,35 \mathrm{~mm}$ (amplitude: 0,10 a $0,20 \mathrm{~mm}$; s: 0,1562) e o comprimento médio do eixo maior da placa fixadora é igual a 1,05mm (amplitude: 0,90 a 1,24mm; s: 0,1003) (Tabs III-IV).

Os ovos de A. phaeopoda são postos em geral isolados (Fig. 11), fixos ao substrato, no sentido vertical; alguns, são postos em grupos de dois ou três, colados, geralmente aos lados, na altura do meio e também fixos aos substrato através da placa fixadora com ou sem pedúnculo. 


\section{Larva de quinto instar}

Aproximadamente 2,3 vezes mais longa que sua maior largura (Figs 22-23); dorso-ventralmente pouco achatada; os lados subparalelos, convergindo suavemente para frente a partir do mesonoto e fortemente para o ápice, a partir do sétimo tergo. Tegumento amarelo com inúmeras e diminutas manchas pretas, às vezes acinzentadas, exceto em volta das chalazas dorsais, nos escolos e na furca anal, que lhe dá aspecto enegrecido. Aos lados com 14 pares de escolos, subiguais em comprimento (com as seguinte mensurações, numa larva de quinto ínstar: 1,25; 1,25; $2,08 ; 1,33 ; 2,00 ; 1,92 ; 1,50 ; 1,33 ; 1,25 ; 1,33 ; 1,33 ; 2,17 ; 2,50 ; 2,33 \mathrm{~mm})$ assim dispostos: três no protórax, dois no mesotórax, um no metatórax e oito abdominais, do primeiro ao oitavo tergo, este dorsalmente com a furca anal, cujos ramos alcançam o quinto tergo (em torno de $2,00 \mathrm{~mm}$ de comprimento) quando voltados para frente; os escolos 12 a 14, levemente recurvados para cima.

Cabeça subarredondada, em vista frontal (Fig. 30); de lado, um pouco achatada. Os parietais, cerca de 1,5 vezes mais longos que largos; com forte depressão, no meio, na altura das antenas, logo atrás do clípeo. Largura média da cápsula cefálica é 1,71 mm (amplitude: 1,65 a 1,75mm; s: 0,0399) (Tab. XI). Antenas com dois artículos, o basal, reduzido a um curto anel e o distal, alongado, um pouco mais longo que a largura de sua base e no ápice com alguns processos sensoriais, destacando-se um, maior. Ocelos, seis a cada lado, dispostos aos pares, sobre pequenos tubérculos, o mais anterior, voltado para frente. Clípeo, cerca de 2,2 vezes mais largo que seu comprimento mediano, margem posterior com forte projeção no meio, os lados convergindo fortemente para frente, margem anterior levemente sinuada. Labro aproximadamente 2,4 vezes mais largo que seu comprimento mediano (Fig. 42), margem posterior levemente bissinuada, margem anterior sinuada no meio e com algumas curtas cerdas, em torno de quatro, em cada metade. Mandíbulas em concha, subretangulares (Fig. 48), cerca de 2,2 vezes mais longas que sua largura basal, no ápice com cinco dentes, de bordos crenulados; destacam-se dois dentes intermediários, maiores; na base, no lado externo e inferior, com forte côndilo. Maxilas com o cardo alongado, quase tão longo quanto o estipe e o palpo maxilar juntos (Fig. 36); estipe quase tão longo quanto o palpo maxilar e o lado interno continuando com a mala globosa; palpo maxilar com dois artículos, o basal, subcilíndrico, pouco mais largo que longo e o distal, subcônico, quase tão longo quanto sua largura basal. Lábio com área do mento e submento membranosa e levemente alargada para trás; estipe anteriormente membranosa e posteriormente, com faixa transversal esclerotinizada projetada no meio; palpos labiais com um artículo, subcônico, quase tão longo quanto sua largura basal.

Placa pronotal bastante ampla, abrangendo quase toda a porção dorsal do pronoto, margem anterior reta e a posterior, com chanfro no meio, superfície com alguns sulcos, depressões e várias chalazas (em torno de 17, em cada metade), dispostas irregularmente, com suave sulco ao longo da linha mediana. Mesonoto cerca de 3,5 vezes mais largo (excluídos os escolos) que seu comprimento mediano; o premesotergito com três chalazas em cada metade, uma anterior muito atrofiada e inconspícua e as demais, maiores, dispostas em fila transversal; o postmesotergito com três, às vezes, quatro, chalazas em cada metade, próximas à linha mediana, 
dispostas em fila transversal e um pouco mais para o lado, com duas chalazas próximas entre si, dispostas longitudinalmente ao eixo do corpo, às vezes, obliquamente e látero-anteriormente, com um grupo de quatro a seis chalazas, geralmente cinco; aos lados, entre o terceiro e quinto par de escolos com projeção onde se situa o primeiro par de espiráculos e o quarto par de escolos. Metanoto semelhante ao mesonoto exceto a projeção látero-anterior, ausente.

Abdômen com o tergo anterior cerca de cinco vezes mais largo que seu coprimento mediano; os tergos dois a seis semelhantes ao anterior; os demais estreitados rapidamente em direção ao ápice. Todos os tergos divididos em pré- e postergitos, por sulco transversal que aos lados, próximo à linha dos espiráculos, se volta para trás. O pretergito do primeiro tergo, com quatro chalazas bem desenvolvidas em cada metade, dispostas em fila tranversal, as três mais externas juntamente com as chalazas dos demais pretergitos, formam três fileiras longitudinais, mais ou menos evidentes; a mais externa, próxima à linha dos espiráculos; próximo e anteriormente às duas chalazas mais internas e também próximo e anteriormente ao espiráculo, com uma ou duas chalazas, muito diminutas e inconspícuas, fixas próximo à linha divisória dos tergos, que também formam fileiras longitudinais, mais ou menos evidentes; os postergitos com duas chalazas que em conjunto formam duas fileiras longitudinais mais ou menos evidentes, uma próxima à linha mediana dorsal e a outra, entre as duas fileiras mais internas das chalazas dos pretergitos.

Aos lados, dos primeiro ao sétimo tergo, os espiráculos, um par por segmento, com peritrema bem saliente, que diminue de tamanho do primeiro ao último.

Esternos torácicos pouco mais de duas vezes mais largos que seu comprimento mediano. Tíbia cerca de 1,5 vezes mais longa que o fêmur; este no ápice com tarsúngulo que apresenta um dente lamelar, no lado interno (Fig. 54).

Esternos abdominais muito alargados e estreitos; o segundo, cerca de seis vezes mais largo que seu comprimento mediano; os demais semelhantes, porém, a partir do quinto, estreitados para trás; o nono e décimo esternos, formando tubo anal que no lado ventral é formado por duas placas esclerotinizadas, divididas ao meio por faixa esbranquiçada.

Coloração. Tegumento amarelo-claro, com inúmeras e diminutas manchas acinzentadas, mais concentradas aos lados onde formam duas faixas longitudinais, no lado dorsal; no meso- e metanoto estas faixas terminam na base dos escolos correspondentes e no abdômen, próximo à linha interna dos espiráculos. A grande densidade dessas manchas confere à larva, às vezes, aspecto acinzentado, principalmente aos lados do tórax, no lado dorsal do abdômen e ao lado dos esternos abdominais; às vezes, os últimos esternos, a partir do quinto, quase totalmente acinzentados. Preto, às vezes, com aspecto mais acinzentado, a metade distal dos escolos, cabeça, placa pronotal, às vezes, não totalmente, partes esclerotinizadas das pernas, esclerito ventral do tubo anal e chalazas; estas, nos tergos abdominais, em volta da base, com anel amarelo, sem as manchas escuras. O meso- e metasterno e os três primeiros esternos abdominais, às vezes, com pequena mancha escura no meio.

Pilosidade. Cabeça com cerdas esparsas, concentradas nos dois terços anteriores dos parietais; clípeo com duas cerdas, uma em cada metade; labro com quatro 
cerdas dispostas em fila transversal na altura do meio e duas cerdas menores, uma em cada metade, próximas à linha mediana e da margem anterior; maxilas com poucas e esparsas cerdas, mais aglomeradas na mala. Cerdas estão presentes nos escolos e nas chalazas dorsais. Furca anal com poucas cerdas na base, do lado posterior. Aos lados do tórax, abdômen e esternos torácicos com poucas cerdas que são mais abundantes nos esternos abdominais. Pernas com inúmeras cerdas, destacando-se uma sobre o dente lamelar do tarsúngulo (Fig. 54). Tubo anal com poucas cerdas, mais abundantes no lado ventral. Ao longo da linha média dos esternos torácicos e dos esternos um a dois, às vezes, também o três, com estreita faixa glabra.

\section{Pupa}

Corpo alongado, cerca de 1,8 vezes mais longo que sua maior largura (excluídos os escolos) (Figs 68-70). Em vista de perfil, dorsalmente convexa, mais fortemente no ápice do abdômen, a partir do quarto tergo; os tergos um a três mais rebaixados, formando depressão larga e transversal; ventralmente aplanada. Vista de cima, os lados (exceto os do pronoto) subparalelos, fracamente convergentes no meta- e mesotórax e fortemente, em direção ao ápice, a partir do quinto tergo. No sentido transversal, dorsalmente, levemente convexa, mais fortemente do sexto tergo ao ápice do abdômen. Superfície com microcanalículos, irregularmente dispostos; às vezes, com aspecto de círculos concêntricos, como no pronoto e metanoto e no lado dorsal do abdômen, com predominância transversal.

O comprimento médio das pupas, macho e fêmea, é respectivavamente 7,80 mm (amplitude: 7,60 a 7,92mm; s: 0,1343) e 8,50 $\mathrm{mm}$ (amplitude: 8,17 e 9,00mm; s: 0,2814) (Tab. XV).

Pronoto cerca de duas vezes mais largo que seu comprimento mediano; área discal mais elevada que as abas, rebaixada somente aos lados e com curto sulco, oblíquo, voltado para fora posteriormente, no meio de cada metade; margem anterior, com pequeno chanfro no meio e os lados, largamente arredondados; margem posterior com forte projeção mediana; ao longo do meio com suave sulco.

Mesonoto com área do escutelo saliente e projetada posteriormente; margem posterior, aos lados fortemente côncava. Élitros voltados para trás e ventralmente alcançando o quinto esterno abdominal. Metanoto, no meio pouco mais longo que o mesonoto; margem posterior quase reta e no meio com leve projeção que é saliente dorsalmente; ao longo do meio, com largo sulco, estreitado suavemente para trás.

Abdômen com o primeiro tergo cerca de sete vezes mais largo que longo (excluídos os escolos); os tergo dois a cinco semelhantes ao primeiro; os tergos quatro e cinco, pouco mais estreitados; do sexto tergo ao último, estreitados rapidamente em direção ao ápice; o oitavo tergo cerca de 2,4 vezes mais largo anteriormente que seu comprimento mediano.

Aos lados com oito pares de escolos, um par por segmento; os cinco anteriores, voltados para fora e para frente e diminuindo gradativamente de tamanho do primeiro ao quinto par (com as seguintes mensurações numa pupa, em milímetros: 1,$08 ; 0,88 ; 0,84 ; 0,76 ; 0,68 ; 0,48 ; 0,48 ; 0,28)$; o sexto e sétimo pares de escolos, voltados para trás e de encontro ao corpo; o oitavo fixo mais ventralmente e o mais curto de todos; o primeiro par tão largo na base quanto seu tergo correspondente e os demais mais estreitos. 
Aos lados, dorsalmente, próximo à base dos escolos, os espiráculos, um par por segmento, do primeiro ao quinto tergo; o anterior com peritrema e óstio maior que os demais que diminuem gradativamente de tamanho, do anterior para o posterior.

Entre a linha dos espiráculos e a linha mediana dorsal, uma fileira de pequenas depressões, que diminuem de tamanho para trás, do primeiro ao sexto tergo.

Cabeça em vista ventral, cerca de duas vezes mais longa que larga; ao longo do meio com suave sulco; no ápice com dois curtos lobos, achatados no sentido transversal. Antenas voltadas para trás e para fora; ápice alcançando a articulação fêmur-tibial anterior, segmentação pouco evidente. Área clípeo-labral, em forma de losango, cerca de duas vezes mais larga que seu comprimento mediano; no meio com largo sulco, do meio até o ápice; no meio da margem anterior, com pequena projeção subtriangular. Mandíbulas, em concha, cerca de duas vezes mais longas que largas; face externa fortemente convexa. Palpos digitiformes; os maxilares pouco mais longos que os labiais.

Perna anterior com fêmur e tíbia, quase do mesmo comprimento e achatados de encontro ao corpo; tarsos com segmentação pouco evidente. Perna média e posterior semelhante a anterior; a posterior com o fêmur e tíbia recobertos pelos élitros, exceto o ápice da articulação fêmur-tibial e o tarso.

Esternos abdominais de um a seis, no meio mais curtos e aos lados cerca de duas vezes mais longos; o sétimo tão longo aos lados como no meio; no último a abertura anal transversal; furca anal com ramos medindo em torno de $0,45 \mathrm{~mm}$, voltados para trás e para fora; na base afastados um do outro em torno de $0,30 \mathrm{~mm}$.

Coloração. Tegumento amarelo, exceto os tergos e esternos sete e oito, de cor amarelo pálido quase esbranquiçado. Pretas as seguintes partes: margem posterior do pronoto; metanoto com faixa transversal no quarto posterior, mais alargada aos lados e ali mais enegrecida; ápice dos escolos um a cinco; área clípeo-labral e palpos, labiais e maxilares, que às vezes têm coloração mais acinzentada, quase preta.

De cor cinza as seguintes partes: cabeça, exceto o sulco ao longo do meio e estreita faixa que acompanha a margem posterior da área clípeo-labral; mandíbulas próximo ao ápice; pronoto com mancha discal sub-retangular, dividida ao meio pelo sulco mediano, os cantos látero-posteriores prolongados um pouco para trás, margem anterior prolongada para frente e a posterior, para trás; mesonoto quase totalmente; élitros com quatro faixas estreitas, alongadas e mais ou menos equidistantes, a mais anterior curta, extendendo-se da base (sob a aba pronotal) até a antena, as duas intermediárias, extendendo-se, a primeira da base até a altura do segundo par de escolos e a segunda, até a altura do quarto par, e a posterior, ao longo da margem posterior e em geral também da margem externa; parte visível das pernas; tergos abdominais um a seis, quase totalmente e no meio, com faixa pouco mais escura; próximo à margem posterior dos tergos três a seis, com faixa transversal, mais escura, no meio pouco mais larga, estendendo-se até próximo à linha dos espiráculos; fileira de depressões de coloração mais escura; peritrema dos espirácu- 
los. A faixa mediana, as manchas correspondentes às depressões e as faixas transversais, às vezes, de coloração mais escura, quase preta.

Pilosidade. Muito escassa, irregularmente distribuída, esbranquiçada e inconspícua. Destacam-se umas poucas cerdas sobre os escolos um a cinco, as maiores alcançando até $0,02 \mathrm{~mm}$ de comprimento. Glabros os escolos seis a oito, a furca anal e as antenas.

\section{Anacassis punctulata (Klug, 1829)}

Figs $6,12,24,25,31,37,43,49,55,71-73,79$

\section{Ovo}

Aproximadamente 2,4 vezes mais longo que sua maior largura; comprimento médio 2,24mm (amplitude 2,16 a 2,40mm; s: 0,0894) e largura média 0,93mm (amplitude 0,92 a 0,96mm; s:0,0300) (Tabs I-II; Fig. 12) ocre, subcilíndrico; no meio mais largo; superfície com pontuação bastante grosseira.

Nas duas extremidades com pequena micrópila, arredondada; a anterior que sempre fica oposta ao substrato, recoberta por substância acastanhada; a posterior, não recoberta, deixando visível a membrana vitelínica. Fixos aos substrato foliar através de curto pedúnculo, subcilíndrico, acastanhado, preso na extremidade láteroposterior e no ápice alargado em fina placa, subcircular e translúcida. O comprimento médio do pedúnculo é $0,96 \mathrm{~mm}$ (amplitude: 0,80 a $1,20 \mathrm{~mm}$; s: 0,1199 ) e o comprimento médio do eixo maior da placa fixadora é $0,95 \mathrm{~mm}$ (amplitude: 0,60 a 1,40mm; s: 0,2572) (Tabs III-IV).

Os ovos são postos em grupos de seis a sete (Fig. 12), no sentido vertical ou levemente oblíquo, colados uns aos outros, lateralmente, próximo a altura do meio, presos ao substrato através de pedúnculo e da placa fixadora.

\section{Larva de quinto ínstar}

Aproximadamente 2,2 vezes mais longa que sua maior largura; dorsoventralmente pouco achatada (Figs 24-25); os lados subparalelos, convergindo fracamente para frente a partir do metatórax e fortemente para o ápice a partir do sexto tergo. Aos lados com 14 pares de escolos, subiguais em comprimento (com as seguintes mensurações numa larva de quinto ínstar, em milímetros: 1,$00 ; 1,00 ; 2,25$; $1,17 ; 2,08 ; 1,67 ; 1,58 ; 1,33 ; 1,25 ; 1,25 ; 1,25 ; 2,48 ; 2,50 ; 2,50)$ assim dispostos: três no protórax, dois no mesotórax, um no metatórax e oito abdominais, do primeiro ao oitavo tergo; este dorsalmente, com furca anal, cujos ramos recurvados para frente, alcançam o quinto tergo (aproximadamente $2,08 \mathrm{~mm}$ de comprimento).

Cabeça subarredondada, em vista frontal (Fig. 31); vista de lado um pouco achatada. Os parietais, cerca de 1,5 vezes mais longos que sua maior largura; logo atrás do clípeo e ao lado da sutura epicranial, com forte depressão e mais dorsalmente com suave sulco ao longo do meio até próximo ao vértice. A largura média da cápsula cefálica é $2,05 \mathrm{~mm}$ (amplitude: 1,92 e 2,20mm; s: 0,1165) (Tab. XII). Antenas com um artículo, subcilíndrico, quase tão longo quanto largo, ápice com alguns processos sensoriais, destacando-se um, maior. Ocelos em número de seis a cada lado, dispostos aos pares, sobre pequenos tubérculos, o mais anterior, logo 
atrás da antena, voltado fortemente para frente. Clípeo, cerca de 2,5 vezes mais largo que seu comprimento mediano, margem posterior com forte projeção mediana, os lados convergindo para frente, margem anterior levemente recurvada. Labro cerca de 2,2 vezes mais largo que seu comprimento mediano (Fig. 43), margem posterior levemente arqueada, margem anterior com forte chanfro no meio e mais para os lados com algumas cerdas muito curtas e inconspícuas, margens laterais largamente arredondadas e convergindo para frente. Mandíbulas subquadradas, cerca de 1,2 vezes mais longas que sua maior largura (Fig. 49), face externa convexa e a interna, côncava, no ápice com cinco dentes destacando-se dois maiores, o mais interno muito reduzido, na base, no lado inferior, com forte côndilo. Maxilas com o cardo alongado (Fig. 37), quase tão longo quanto o estipe e o palpo maxilar juntos; estipe quase tão longo quanto o palpo maxilar e no lado interno continuado com a mala globosa; palpo maxilar com dois artículos, o basal, subcilíndrico, pouco mais largo que longo e o distal, subcônico, quase tão longo quanto sua largura basal. Lábio com área do mento e submento membranosa e levemente alargada para trás; estipe anteriormente membranosa e posteriormente esclerotinizada; palpos uniarticulados, subcônicos, quase tão longos quanto a largura basal.

Placa pronotal bastante ampla, abrangendo quase toda a porção dorsal do pronoto; margem anterior reta e a posterior com chanfro no meio; superfície com alguns sulcos irregularmente dispostos; ao longo do meio com suave sulco. Mesonoto cerca de três vezes mais largo que seu comprimento mediano (excluídos os escolos); o premesotergito com duas ou três chalazas a cada lado, dispostas transversalmente; postmesotergito com inúmeras chalazas, mais abundantes aos lados, destacando-se duas ou três, próximas à base do quinto par de escolos, bem maiores que as demais. Látero-anteriormente com projeção onde se situa o primeiro par de espiráculos e o quarto par de escolos. Metanoto semelhante ao mesonoto, excetuando-se a projeção látero-anterior, ausente. Abdômen, com os sete primeiros tergos divididos em pre- e postergitos, por sulco transversal, aos lados voltado para trás pouco antes da linha dos espiráculos; os pretergitos, em geral com duas a quatro chalazas muito atrofiadas, a cada lado, dispostas em fila transversal; os portergitos em geral com duas a cinco chalazas, em cada metade, dispostas em fila transversal e também atrofiadas. Aos lados do primeiro ao sétimo tergo, os espiráculos, um par por segmento, com peritrema bem saliente que diminue de tamanho, do primeiro ao último. Esternos torácicos em torno de duas vezes mais largos que longos. Pernas com a tíbia pouco mais curta que o fêmur e no ápice o tarsúngulo que apresenta um pequeno dente lamelar (Fig. 55). Esternos abdominais muito alargados e estreitos; o segundo, cerca de seis vezes mais largo que seu comprimento mediano; os demais semelhantes, porém, a partir do quinto, estreitados para trás; o nono e o décimo esternos, formando o tubo anal, que no lado ventral tem uma placa esclerotinizada, dividida ao meio por faixa esbranquiçada.

Coloração. Tegumento amarelado. Pretas as seguintes partes: cabeça quase totalmente; ápice dos escolos e furca anal; pronoto com algumas manchas; meso- e metanoto quase totalmente assim como os tergos abdominais onde se nota nos terços laterais uma faixa mais enegrecida; ao longo da linha dorsal mediana, uma fileira de manchas pretas, que se alargam nos tergos abdominais dois a cinco; ventralmente 
aos lados; os esternos cinco a oito às vezes, totalmente; o meso- e metasterno e os três primeiros esternos abdominais, com mancha mediana, enegrecida.

Pilosidade. Cabeça com cerdas esparsas distribuídas nos dois terços anteriores dos parietais e ausentes nas depressões; clípeo com uma cerda a cada lado; labro com quatro cerdas, dispostas em fila transversal, duas em cada metade; maxilas com cerdas esparsas mais abundantes na mala; lábio com três cerdas no estipe e três, na área do mento e submento; nos tergos torácicos e abdominais, com poucas e esparsas cerdas, muito curtas, no ápice das chalazas e nos escolos; furca anal com cerdas curtas no lado posterior e basal; ventralmente com muitas cerdas aos lados do tórax, nos esternos torácicos e abdominais; no prosterno com cerdas em menor quantidade; a região das manchas pretas e tarsúngulo (Fig. 55), glabros.

\section{Pupa}

Corpo alongado, cerca de 1,7 vezes mais longo que sua maior largura, excluídos os escolos (Figs 71-73). Em vista de perfil, dorsalmente convexa, mais fortemente no ápice do abdômen, a partir do quinto tergo; ventralmente aplanada. Vista de cima, os lados (exceto os do pronoto) do abdômen, do primeiro ao quinto tergo, subparalelos; convergindo levemente para frente e para trás, fortemente, a partir do sexto tergo. No sentido transversal levemente convexa no pro-, meso- e metanoto e até o quinto tergo; partir do sexto tergo até o ápice, mais fortemente. Superficie dorsal com microcanalículos irregularmente dispostos, exceto o último tergo, liso.

O comprimento médio da pupa é 10,83 mm (amplitude: 10,50 a 11,17mm; s: 0,2641) (Tab. XVI).

Pronoto cerca de 1,8 vezes mais largo que seu comprimento mediano; área discal continuada com as abas, sem mostrar linha divisória; margem anterior largamente arredondada, no meio com pequeno chanfro; margens laterais fortemente convexas; margem posterior com forte projeção mediana que tem um pequeno chanfro no meio; ao longo do meio, com suave sulco; próximo ao meio de cada metade com pequenas e inconspícuas depressões. Mesonoto com margem posterior fortemente projetada no meio e para os lados côncava. Metanoto no meio tão longo quanto o mesonoto; margem anterior fortemente bilobada; posteriormente, no meio, com leve e curta projeção e mais para os lados, quase reta e na altura do espiráculo anterior levemente côncava.

Abdômen com o primeiro tergo cerca de 7,6 vezes mais largo que seu comprimento mediano (excluídos os escolos); tergos dois a quatro, semelhantes ao primeiro; os tergo um e dois, no meio, próximo a margem posterior, com pequena protuberância semicônica; os demais estreitados rapidamente para trás; o último com ápice largamente arredondado e margem anterior cerca de três vezes mais larga que seu comprimento mediano. Aos lados com oito pares de escolos, um par por segmento; os cinco anteriores voltados para fora e diminuindo de tamanho, gradativamente, do primeiro ao quinto par (com as seguintes mensurações numa pupa, em milímetros: 1,$25 ; 1,08 ; 0,92 ; 0,92 ; 0,75 ; 0,42 ; 0,42$ e 0,33$) ;$ o primeiro, na base tão largo quanto o tergo correspondente; os demais mais estreitos na base que os tergos correspondentes; o sexto e sétimo pares de escolos, voltados para trás; o oitavo, fixo mais ventralmente no oitavo esterno e voltado para o meio. 
Aos lados, dorsalmente, próximo à base dos escolos e próximo à margem anterior dos tergos um a seis os espiráculos; o anterior simples e peritrema maior que os demais, que diminuem de tamanho até o quinto; os espiráculos, do segundo ao quinto tergo, bíforos; o óstio, mais externo, menor que o mais interno, mas aumentando gradativamente para trás, até o sexto tergo, que só possui um.

Entre a linha dos espiráculos e a linha mediana dorsal do abdômen, há duas fileiras de pequenas depressões, um par por tergo, do primeiro ao sexto.

Cabeça em vista ventral, cerca de 1,4 vezes mais longa do que larga; ao longo do meio, levemente sulcada; ápice com dois lobos curtos e achatados no sentido transversal. Antenas voltadas para trás e para fora; o ápice alcançando a articulação fêmur-tibial anterior; segmentação pouco evidente; em cada artículo, no lado mais ventral, com pequeno nódulo. Área clípeo-labral, cerca de uma vez e meia mais longa que larga. Mandíbulas em concha; face externa convexa; quase tão longas quanto largas. Palpos com fraca segmentação; os labiais digitiformes e curtos; os maxilares, cerca de duas vezes mais longos que os labiais.

Pernas anteriores com fêmur e tíbia achatados de encontro ao corpo; tarsos de segmentação pouco evidente. Perna média e posterior semelhantes a anterior; a posterior, recoberta pelos élitros, exceto o ápice da articulação fêmur-tibial e o tarso.

Coloração. Tegumento amarelo-pálido. Pretas as seguintes partes: margem posterior do pronoto; peritrema dos espiráculos da linha interna; metade apical do primeiro par de escolos e ápice dos escolos dois, três e quatro. De cor cinza claro as seguintes partes: área do disco pronotal com mancha irregular mais alargada no meio e ali dividida pelo sulco longitudinal e mediano; mesonoto com mancha látero-posterior, alargada e de contornos indefinidos, próximo à base dos élitros; metanoto com faixa transversal posterior; abdômen com quatro faixas: duas ao lado de cada metade, correspondendo às duas linhas de depressões e uma mediana, do primeiro ao sexto tergo, que se prolonga para os lados, até próximo aos espiráculos, nos tergos quatro, cinco e seis; linha externa dos espiráculos; élitros com três faixas equidistantes: as duas anteriores, prolongando-se da base até próximo à margem externa, mais fracas e a posterior, mais forte, ao longo da margem posterior e externa; cabeça e pernas.

Pilosidade. Sobre todo o corpo com pilosidade curta, em geral menor do que $0,05 \mathrm{~mm}$, muito esparsa, irregularmente distribuída, esbranquiçada e inconspícua; escolos com cerdas sobre pequenos processos digitiformes. Glabros os escolos seis a oito, furca anal e élitros.

\section{DISCUSSÃo}

\section{Ovos}

Os ovos das espécies de Anacassis, estudados na presente pesquisa (Figs 7-12) são morfologicamente semelhantes quanto a cor, forma, posição das micrópilas, pontuação, pedúnculo, placa fixadora e o pequeno capuz formado por substância acastanhada sobre o polo anterior; as diferenças dizem respeito às medidas de comprimento e largura do ovo, número de ovos por postura, comprimento do pedúnculo e do eixo maior da placa fixadora. 
Nas tabelas I a IV são mostradas as semelhanças e diferenças estatísticas relativas ao comprimento, largura, comprimento do pedúnculo e do eixo maior da placa fixadora.

O comprimento médio dos ovos de Anacassis dubia (Tab. I) não difere significativamente do comprimento médio dos ovos de $A$. phaeopoda mas difere do das outras espécies estudadas. O comprimento médio dos ovos de $A$. fuscata e $A$. fuscata (forma) não diferem significativamente entre si; os ovos de A. fuscata (forma) não diferem significativamente do comprimento médio dos ovos de $A$. phaeopoda. Os ovos de $A$. languida e $A$. punctulata diferem significativamente entre si, quanto ao comprimento médio e também em relação aos demais, sendo os ovos de $A$. punctulata os mais longos, seguindo-se em ordem decrescente os ovos de $A$. languida, A. dubia, A. phaeopoda, A. fuscata (forma) e A. fuscata.

A largura média dos ovos de $A$. punctulata (Tab. II) não difere significativamente da largura média dos ovos de A. languida; a menor largura média foi constatada nos ovos de $A$. fuscata e que não difere significativamente da largura média dos ovos de $A$. fuscata (forma) que não diferem significativamente da largura média dos ovos de $A$. dubia cujos ovos também não diferem significativamente da largura média dos ovos de A. phaeopoda.

O comprimento médio dos pedúnculos (Tab. III) dos ovos de A. fuscata, A. fuscata (forma) e A. phaeopoda não diferem significativamente entre si, mas diferem significativamente do comprimento médio dos pedúnculos de $A$. dubia, A. languida e $A$. punctulata, que não diferem significativamente entre si.

O comprimento médio do eixo mai; la placa fixadora (Tab. IV) de $A$. punctulata não difere significativamente de $t_{\star}$ dubia, A. languida e A. phaeopoda também não diferem significativamente entre si; o de $A$. fuscata não difere significativamente do comprimento médio do eixo maior da placa fixadora de A. dubia, A. fuscata (forma) e $A$. languida, cujos comprimentos médios não diferem significativamente entre si.

O ovo de A. cribrum, descrito por BUZZI (1975a), tem o aspecto externo bem como o modo de fixação, semelhantes aos dos ovos das espécies estudadas; o comprimento e a largura médias, 1,74 e $0,78 \mathrm{~mm}$, respectivamente, estão muito próximos dos de $A$. fuscata, A. fuscata (forma) e de $A$. phaeopoda. O comprimento médio do pedúnculo do ovos de $A$. cribrum $(0,20 \mathrm{~mm})$, está muito próximo de $A$. fuscata, A. fuscata (forma) e A. phaeopoda.

O ovo de A. sulcipennis, descrito por ARAVENA (1960), se assemelha aos ovos descritos neste trabalho e também aos de A. cribrum e $A$. fuscata descritos por Buzzi (1975a, 1975b). O comprimento dos ovos de A. sulcipennis é, segundo o citado autor "de unos dos milímetros" o que está muito próximo do comprimento do ovo de $A$. languida, embora esta conclusão não seja muito acertada, devido a imprecisão da medida apresentada.

$\mathrm{O}$ arranjo dos ovos nas posturas de Anacassis spp. é muito semelhante entre as várias espécies estudadas neste trabalho. A única espécie que se distingue das demais é $A$. phaeopoda, cujos ovos são depositados isoladamente ou mais raramente em grupos de dois e, às vezes, três. 
O número médio de ovos de $A$. dubia por postura (Tab. V) não difere significativamente de $A$. fuscata cuja média de ovos por postura também não difere, no mesmo nível de significância, de $A$. fuscata (forma) e esta difere significativamente de A. dubia.

A média de ovos por postura de $A$. languida é 6,7 , segundo BUZZI \& GARCIA (1983), e a de $A$. punctulata 6,5 ovos por postura, uma média não confiável, devido terem sido observadas somente duas posturas, uma com seis e outra com sete ovos.

O número médio de ovos por postura de A. cribrum, segundo BUZZI (1975a) e de A. fuscata, segundo Buzzi (1975b), é 23,39 e 19,20 ovos, o número de ovos por postura variando de dois a 54 e cinco a 36 (não se considerando os ovos isolados), respectivamente; na presente pesquisa o número médio de ovos por postura em $A$. fuscata é 12,54, variando de cinco a 18 . Essa diferença em relação ao resultado obtido para $A$. fuscata por BUZZI (1975b) se deve ao número relativamente pequeno de posturas observadas.

Os ovos de A. sulcipennis, segundo ArAvEnA (1960), são postos em grupos de sete a 28, cuja amplitude é menor (Tab. V) da encontrada em A. cribrum cujo Coeficiente de Variação $(48,31)$ é o maior de todas as espécies estudadas como também a amplitude ( 2 a 54 ovos).

\section{Larvas}

As larvas das espécies de Anacassis estudadas (Figs 13-25) apresentam os seguintes caracteres: cabeça (Figs 26-31) de aspecto arredondado em vista frontal e um pouco achatada em vista lateral, atrás do clípeo, a cada lado, com forte depressão; ocelos, em número de seis aos lados de cada parietal, sobre pequenas elevações, subcônicas, dispostos aos pares e o mais anterior voltado para frente; antenas com dois artículos, exceto em A. languida e A. punctulata, com processos sensoriais no ápice, destacando-se um maior; clípeo alargado, os lados convergindo fortemente para frente e para o meio, com duas cerdas, uma a cada lado; labro (Figs 38-43) com chanfro na margem anterior e os lados arredondados, convergindo para frente e para o meio, com quatro a seis cerdas, dispostas quatro no meio e duas, menores e mais anteriores; mandíbulas (Figs 44-49) com cinco dentes, destacandose dois maiores; maxilas (Figs 32-37) com o cardo e estipe alongados, mala globosa, palpos biarticulados, com algumas cerdas esparsas; lábio com área do mento e submento membranosa, alargada para trás, com três cerdas em cada metade, estipe transversal e palpos uniarticulados, subcônicos; tórax com placa pronotal, meso-e metanoto, divididos em pré- e postergitos; aos lados com 14 pares de escolos; pernas curtas e grossas e no ápice com tarsúngulo, com dente laminar (Figs 50-55) e uma cerda basal, exceto em $A$. punctulata e $A$. languida cujo tarsúngulo, glabro, tem aspecto um pouco diferenciado das demais espécies; cerdas na cabeça esparsas, em geral mais abundantes na região que fica entre o clípeo e os ocelos, e no restante do corpo, mais abundantes no lado ventral; a coloração das larvas é de modo geral amarelada, com pequenas manchas acinzentadas, às vezes bastante concentradas $o$ que lhe confere aspecto acinzentado ou enegrecido. Essas características são também encontradas em A. cribrum e A. fuscata, e A. sulcipennis cujas larvas foram descritas, respectivamente por BuZZI (1975a, 1975b) e ARAVENA (1960). 
As principais diferenças entre as larvas estudadas estão relacionadas a seguir. Parietais de A.languida, com um grupo de cerdas acima da linha dos ocelos (Fig. 29) o que não ocorre nas demais espécies; mandíbulas com uma ou duas cerdas no lado externo, exceto em em A. punctulata e A. phaeopoda, o que também ocorre em A.cribrum, segundo BuzZI (1975a, fig. 24), com dentes de bordos lisos em $A$. languida e A. punctulata e de bordos crenulados em A. dubia, A. fuscata e A. fuscata (forma); labro, superfície com quatro a seis cerdas e na margem anterior com algumas curtas cerdas, ausentes em $A$. languida; maxilas: cardo com seis cerdas em A. languida, quatro em A. punctulata e três em A. dubia, A. fuscata e A. fuscata (forma); estipe com duas cerdas em A.languida, três em A. fuscata, A.fuscata (forma) e A. phaeopoda, quatro em A. dubia e cinco em A. punctulata; lábio: estipe com uma cerda em A. languida, duas em A.phaeopoda, três em A. fuscata e A. fuscata (forma) e A. dubia, quatro em A. punctulata. Chalazas, no lado dorsal, bem evidentes em A. fuscata, A.f uscata (forma), A. phaeopoda; em A. languida e A. punctulata as chalazas são atrofiadas e inconspícuas o que também ocorre em A. cribrum, segundo BuZZI (1975a, Fig. 21) e estão ausentes em A. dubia. Em A. sulcipennis, ARAVENA (1960) afirma “....El segundo y tercero [anillos toracicos] com una hendidura transversal presentando pequeños botones protuberantes negros no muy definidos según los casos".

A larva de quinto ínstar de A. dubia, com o corpo amarelo-esbranquiçado, exceto as seguintes partes pretas: peritremas, faixa transversal na base da furca anal, escolos e ramos da furca anal, exceto próximo à base; a larva de quarto ínstar com os escolos totalmente pretos e com manchas distribuídas dorsalmente; A. fuscata e A. fuscata (forma) com duas manchas pretas, nos terços laterais do meso- e metatórax, continuadas para trás com algumas manchas acinzentadas, muito fracas, escolos totalmente pretos, às vezes um pouco acinzentados; em $A$. languida o tórax, quase totalmente preto e o abdômen aos lados, ao longo da linha dos espiráculos e três fileiras de manchas, a mediana, com manchas alongadas e as laterais, com manchas subarredondadas; ventralmente preta aos lados e totalmente a partir do quarto esterno abdominal e com uma mancha preta, subarredondada, mediana e anterior, no meso-, metasterno e nos dois primeiros esternos abdominais; em $A$. phaeopoda com duas faixas longitudinais acinzentadas nos terços laterais do tórax e do abdômen, escolos com a metade distal preta, exceto os dois pares anteriores, quase totalmente; em $A$. punctulata no lado dorsal com manchas acinzentadas, escolos pretos apicalmente e no lado ventral, acinzentado aos lados e no oitavo esterno totalmente; manchas arredondadas acinzentadas, no meio do meso- e metasterno e nos primeiros quatro esternos abdominais.

Anacassis cribrum, segundo Buzzi (1975a), dorsalmente é preta, ventralmente amarela ao longo do meio e preta aos lados e posteriormente; meso- e metasterno, e nos três primeiros esternos abdominais com pequenas manchas alongadas e escuras no meio; A. sulcipennis, segundo ARAVEna (1960), que descreve o quarto estádio como sendo o último, "el primer anillo torácico presenta un escudete rugoso com una línea clara en el medio. El segundo y tercero con una hendidura transversal presentando pequeños botones protuberantes negros no muy bien definidos según los casos. Entre éstos y la parte lateral va una línea obscura. 
Cabeza, patas e espículas negras. El cuerpo con tonalidad amarillenta com pontuación obscura en todo su recorrido transversal"... "Ventralmente y a partir del segundo par de patas, cada anillo presenta un punto obscuro en su parte media. Dichos puntos son seis y correspondem a los anillos torácicos segundo y tercero y los restantes a los primeros segmentos abdominales".

As larvas de quarto ínstar das espécies estudadas são morfologicamente semelhantes às de quinto ínstar, exceto no tamanho, no entanto a larva de quarto ínstar de $A$. dubia, é bem diferenciada da larva de quinto ínstar e as principais diferenças além do tamanho são: cabeça enegrecida com manchas amarelas, placa pronotal quase totalmente enegrecida, meso-, metanoto e tergos abdominais com inúmeras manchas pretas, escolos e furca anal totalmente pretos.

\section{Pupas}

As pupas das espécies de Anacassis da presente pesquisa (Figs 56-73), apresentam em comum os seguintes caracteres: dorsalmente convexa e ventralmente aplanada, corpo oval alongado; tegumento em geral glabro, liso e de cor amarelada; pronoto mais largo na base que o mesotórax e encobrindo a cabeça, superfície som sulco mediano longitudinal; pernas achatadas de encontro ao corpo; aos lados do abdômen com oito pares de escolos, os cinco anteriores voltados para fora e para frente e os demais voltados para trás ou para o meio e de encontro ao corpo; no ápice a furca anal, muito curta; dorsalmente o abdômen com faixa preta ao longo do meio, também encontrada em A. cribrum, segundo BUZZI (1975a); em A. phaeopoda e $A$. punctulata essa faixa longitudinal é acinzentada.

As principais diferenças estão relacionadas a seguir. Pronoto de $A$. dubia, $A$. fuscata e A. fuscata (forma) com uma mancha preta mediana, alongada, dividida ao meio por sulco longitudinal; a cada lado do disco de $A$. fuscata, com pequena mancha de contornos irregulares, às vezes ligada à mancha longitudinal; em $A$. languida com mancha alongada longitudinal inconspícua que se prolonga para os lados, na altura do meio o que também ocorre em $A$. cribrum, segundo BUZZI (1975a); $A$. phaeopoda com grande mancha discal acinzentada, dividida ao meio por sulco longitudinal e prolongada para frente e para trás e $A$. punctulata com uma grande mancha acinzentada, inconspícua, que ocupa quase toda a região discal.

Abdômen, dorsalmente, com um fileira de pequenas depressões a cada lado em A. dubia, A. fuscata, A. fuscata (forma), A. languida e A. phaeopoda e com duas fileiras de pequenas depressões em $A$. cribrum, segundo BUZZI (1975a), e $A$. punctulata. Apresentam cinco espiráculos, a cada lado, próximo à base dos escolos um a cinco, A. dubia, A. phaeopoda e A. sulcipennis, segundo ARAVENA (1960); $A$. fuscata e A. fuscata (forma) com seis espiráculos a cada lado, o sexto muito atrofiado; BUZZI (1975b) afirma que $A$. fuscata tem cinco espiráculos; A. languida tem sete espiráculos a cada lado, sendo o sexto e o sétimo, atrofiados; $A$. punctulata apresenta seis espiráculos, sendo os do segundo ao quinto, bíforos.

A. dubia aos lados do meso- e metanoto e do abdômen, do primeiro ao sexto tergo, com faixa castanho-avermelhada, o que a distingue de todas as espécies estudadas; A. cribrum, segundo BuZzi (1975a), apresenta, também aos lados do abdômen, uma faixa, porém de cor preta. Élitros de A. dubia com uma faixa preta 
na margem posterior o que também ocorre em A. languida cuja faixa é mais alargada; A. punctulata com três faixas, as duas anteriores mais acinzentadas e a posterior, preta; A. fuscata com quatro faixas pretas, A. fuscata (forma) com três faixas acinzentadas e uma, mais posterior preta; $A$. phaeopoda com quatro faixas acinzentadas.

Abdômen, dorsalmente, sem faixas pretas transversais em A. languida; em A. dubia com uma faixa preta, bem delimitada, no primeiro tergo; A. fuscata com faixas pretas transversais nos tergos três a seis, às vezes com faixas encurtadas; $A$. fuscata (forma) com faixa preta transversal nos tergos três a seis e, às vezes, nos tergos três e seis com faixas encurtadas; A. cribrum, segundo BuZZI (1975a), com faixas pretas transversais nos tergos três a seis; em $A$. phaeopoda com faixas acinzentadas transversais nos tergos três a seis; A. punctulata com faixas acinzentadas transversais nos tergos quatro a seis.

Anacassis languida com uma fileira de manchas pretas a cada lado do primeiro ao sexto tergo do abdômen, situada entre a faixa mediana longitudinal e a linha dos espiráculos, cujo peritrema é preto, também encontradas no metanoto; $A$. punctulata com duas fileiras de manchas pretas, às vezes, acinzentadas, situadas entre a faixa mediana longitudinal do abdômen e a linha dos espiráculos, do primeiro ao sexto tergo. A. sulcipennis, segundo ARAVENA (1960), tem a seguinte coloração: "dorsalmente es de color amarillento pajizo con manchas y líneas pardas que bordean al segundo anillo torácico. Longitudinalmente e a partir de este anillo, una línea parda recorre los segmentos abdominales presentando escotaduras e ensanchamientos hasta perder-se en el último. Entre un anillo e outro existen franjas del mismo color...".

Comparando-se a média de comprimento das pupas machos de A. dubia, A. fuscata, A. fuscata (forma) e A. phaeopoda (Tab. XV) nota-se que não há diferença significativa, o mesmo acontecendo com a média de comprimento das pupas fêmeas; a diferença é significativa quando comparamos a média de comprimento de pupas machos e pupas fêmeas da mesma espécie.

Comparando-se a média de comprimento das pupas das espécies de Anacassis, estudadas na presente pesquisa, (Tab. XVI), sem distiguir machos e fêmeas, não há diferença significativa entre a média de comprimento das pupas de A. dubia, A. fuscata, A. fuscata (forma); a média de comprimento da pupa de A.phaeopoda, não difere significativamente da média de comprimento das pupas de $A$. dubia e $A$. fuscata, mas difere da pupa de $A$. fuscata (forma); a média de comprimento das pupas de $A$. languida e $A$. punctulata difere significativamente entre si e também das demais espécies.Em A.cribrum, segundo BuZzI (1975a), o comprimento médio da pupa é $8,14 \mathrm{~mm}$, muito próximo da média de comprimento da pupa de $A$. phaeopoda. 


\section{Chave para identificação das larvas de quinto ínstar de Anacassis}

1. Lado dorsal totalmente preto . ...................... cribrum

- Lado dorsal amarelo, com manchas pretas ou acinzentadas . . . . . . . . . 2

2. Totalmente amarelo-esbranquiçada, exceto peritremas, escolos e faixa posterior transversal, pretos . . . . . . . . . . . . . . . . . . . dubia

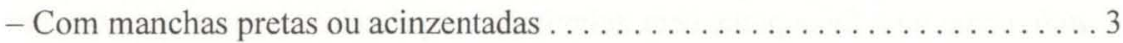

3. Abdômen aos lados preto e na região central amarelo, com três fileiras de manchas

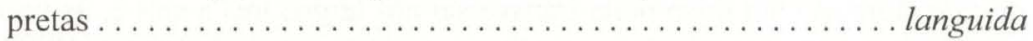

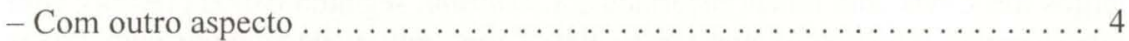

4. Meso-, metanoto e abdômen com fileira de manchas pretas ao longo do meio; escolos amarelados, exceto o ápice, preto ............... punctulata

- Abdômen sem fileira de manchas ou com curta fileira de manchas acinzentadas do tergo dois ao seis; escolos somente pela metade ou totalmente pretos . .5

5. Os lados do meso-, metanoto e abdômen, com faixa acinzentada; escolos com a metade distal preta ou acinzentada .................. phaeopoda

- Os lados do meso- e metanoto pretos ou acinzentados; escolos em geral totalmente pretos ............................... fuscata

\section{Chave para identificação das pupas de Anacassis}

1. Abdômen, no lado dorsal após o primeiro tergo, sem faixas transversais . . . . 2

- Abdômen, no lado dorsal, com faixas transversais pretas ou acinzentadas . . . . 3

2. Aos lados do abdômen com faixa vermelho-acastanhada e no meio, com grande

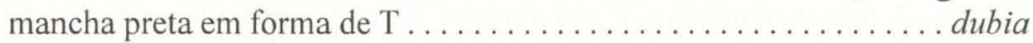

- Dorsalmente o abdômen, com três fileiras de manchas pretas (excluídos os

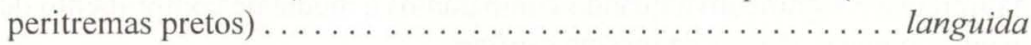

3. Abdômen, dorsalmente, com faixa preta ao longo da linha dos espiráculos e nos tergos três a seis com faixas transversais . ................ cribrum

- Abdômen sem faixa preta aos lados . . . . . . . . . . . . . . . . . 4

4. Abdômen, dorsalmente com cinco fileiras de manchas (excluídos os peritremas pretos) acinzentadas; a fileira mediana com manchas mais alongadas; com faixas transversais pretas nos tergos quatro a seis ......... punctulata

- Abdômen dorsalmente com três fileiras de manchas (excluídos os peritremas); abdômen com faixas transversais pretas ou acinzentadas . ......... 5

5. Faixas transversais pretas, nos tergos três a cinco ou quatro a seis ...... fuscata - Faixas transversais acinzentadas nos tergos três a seis ........... phaeopoda

\section{CICLO EVOLUTIVO}

\section{PERÍODO DE INCUBAÇÃo}

A duração média, em dias, a respectiva amplitude e Desvio Padrão, entre parêntesis, do período de incubação (Tab. VI) de Anacassis dubia, A. fuscata, A. 
fuscata (forma), A. languida e A. phaeopoda, é respectivamente: 11,11 (9 a 13; $1,4489) ; 6,22$ (3 a $8 ; 1,4371) ; 6,15$ (6 a 7; 0,3663); 12,67 (12 a 14; 0,8165) e 7,96 (7 a 9; 0,6381). As médias de duração do período de incubação de $A$. fuscata e $A$. fuscata (forma) não diferem entre si significativamente, mas diferem das demais médias que também diferem entre si.

Anacassis fuscata, segundo BUZZI (1975b), apresenta a média de duração do período de incubação de 9,4 dias, à temperatura média de $21,9^{\circ} \mathrm{C}$, o que difere da média obtida na presente pesquisa para $A$. fuscata de 6,22 dias, em Temperatura de $25^{\circ} \mathrm{C}$. Em A. cribrum, segundo BuZZI (1975a), a duração média do período de incubação é 11,2 dias, à temperatura média de $23^{\circ} \mathrm{C}$, o que se aproxima muito da duração média do período de incubação de $A$. dubia. A duração média do período de incubação de A. languida obtida na presente pesquisa, é um pouco menor da apresentada por BUZZI \& GARCIA (1983): 13,5 dias, obtida em temperaturas diárias que variaram de 20,5 a $22,8^{\circ} \mathrm{C}$. Em A. sulcipennis, segundo ARAVENA (1960), a duração do período de incubação foi de nove dias, dado obtido em Santa Rosa, La Pampa (Argentina), em condições de ambiente e temperatura de verão, não mencionada pelo autor.

\section{Número de ínstares e largura das cápsulas cefálicas}

As larvas das espécies de Anacassis estudadas apresentam cinco ínstares, como também A. cribrum segundo BUZZI (1975a) e A. sulcipennis apresenta quatro "estádios" segundo ARAVENA (1960).

A largura média, em milímetros, das cápsulas cefálicas dos ínstares larvais, estão representadas nas tabelas VII a XIII e a seguir discutidas.

Em A. dubia, a largura média, em milímetros, a respectiva amplitude e Desvio Padrão, entre parêntesis, das cápsulas cefálicas, do primeiro ao quinto ínstar larval, foi respectivamente: $0,56(0,52$ a 0,$60 ; 0,0241) ; 0,76(0,72$ a 0,$80 ; 0,0229)$, $0,99(0,94$ a 1,$04 ; 0,0345), 1,25(1,18$ a 1,$32 ; 0,0405)$ e $1,54(1,44$ a 1,$68 ; 0,0767)$ (Tab. VII). A figura 74, representa a Reta de Regressão linear do crescimento geométrico da largura da cápsula cefálica em função dos ínstares larvais; a equação desta reta é: $Y=0,285+0,245 \mathrm{X}$ e o Coeficiente de correlação é 0,99 o que é altamente significativo.

Em A. fuscata, a largura média, em milímetros, das cápsulas cefálicas, a respectiva amplitude e Desvio Padrão, entre parêntesis, do primeiro ao quinto ínstar larval, foi respectivamente: $0,48(0,46$ a 0,$50 ; 0,0141) ; 0,67(0,64$ a 0,$70 ; 0,0195)$, $0,87(0,82$ a 0,$90 ; 0,0301) ; 1,15(1,06$ a 1,$28 ; 0,0578)$ e $1,58(1,50$ a 1,$73 ; 0,0636)$ (Tab. VIII). A figura 75, representa a Reta de Regressão linear do crescimento geométrico da largura da cápsula cefálica em função dos ínstares larvais; a equação desta reta é: $Y=0,1460+0,2680 \mathrm{X}$ e o Coeficiente de correlação linear é 0,98 , o que é altamente significativo.

Em A. fuscata (forma), a largura média, em milímetros, das cápsulas cefálicas, a respectiva amplitude e Desvio Padrão, entre parêntesis, do primeiro ao quinto ínstar larval, foi respectivamente: $0,48(0,46$ a 0,$50 ; 0,0172) ; 0,67(0,64$ a 0,70 ; $0,0222) ; 0,89(0,82$ a 0,$90 ; 0,0257) ; 1,17(1,06$ a 1,$28 ; 0,0509)$ e $1,54(1,50$ a 1,$73 ;$ 0,0779 ) (Tab. IX). A figura 76 representa a Reta de regressão linear do crescimento 
geométrico da largura da cápsula cefálica em função dos ínstares larvais; a equação desta reta é: $Y=0,3156+0,2266 \mathrm{X}$ e o Coeficiente de correlação linear é igual 0,97, altamente significativo, sendo este o menor Coeficiente de correlação linear dentre as espécies estudadas na presente pesquisa.

BUZZI (1975b) obteve para A. fuscata, as seguintes médias, em milímetros, da largura das cápsulas cefálicas dos ínstares larvais, respectivamente, do primeiro ao quinto ínstar (entre parêntesis a amplitude): 0,49 ( 0,46 a 0,52); 0,67 (0,60 a 0,72); $0,92(0,90$ a 0,96$) ; 1,22(1,12$ a 1,34$) ; 1,65(1,52$ a 1,84$)$. Esses resultados, obtidos de larvas criadas sob Temperatura média de $21,9^{\circ} \mathrm{C}$, não correspondem totalmente aos obtidos na presente pesquisa mas estão dentro dos limites estabelecidos pela amplitude, exceto os valores do terceiro ínstar, um pouco superiores.

Em A. languida, a largura média, em milímetros, das cápsulas cefálicas, a respectiva amplitude e Desvio Padrão, entre parêntesis, do primeiro ao quinto ínstar larval, foi respectivamente: $0,65(0,62$ a 0,$70 ; 0,0267) ; 0,84(0,80$ a 0,$87 ; 0,0287)$; $1,13(1,08$ a 1,$20 ; 0,0376) ; 1,47(1,36$ a 1,$58 ; 0,0802)$ e $1,83(1,70$ a 1,$99 ; 0,1053)$ (Tab. X). A figura 77 representa a Reta de Regressão linear do desenvolvimento geométrico da cápsula cefálica em função dos ínstares larvais; a equação deste reta é: Y=0,2870 + 0,2990 X e o Coeficiente de Correlação linear é 0,99 , o que é altamente significativo.

BUZZI \& GARCIA (1983) obtiveram para A. languida, as seguintes médias, em milímetros, da largura das cápsulas cefálicas dos ínstares larvais, respectivamente, do primeiro ao quinto ínstar (entre parêntesis a amplitude): $0,61(0,58$ a 0,66); $0,86(0,76$ a 0,88$) ; 1,12(1,08$ a 1,20$) ; 1,51(1,34$ a 1,68) e 2,05 (2,00 a 2,10). Esses resultados, obtidos de larvas criadas sob temperaturas que variaram de $20,5 \mathrm{a} 22,8^{\circ} \mathrm{C}$, não correspondem totalmente aos obtidos na presente pesquisa, mas estão dentro dos limites estabelecidos pela amplitude, exceto os valores do último ínstar, um pouco superiores.

Em A. phaeopoda, a largura média, em milímetros, das cápsulas cefálicas, a respetiva amplitude e Desvio Padrão, entre parêntesis, do primeiro ao quinto ínstar larval foi, respectivamente: $0,56(0,50$ a 0,$58 ; 0,0275) ; 0,76(0,72$ a 0,$78 ; 0,0172)$; $1,00(0,94$ a 1,$08 ; 0,0448) ; 1,34(1,28$ a 1,$36 ; 0,0565)$ e $1,71(1,65$ a 1,$75 ; 0,0399)$ (Tab.XI). A firgura 78 mostra a Reta de Regressão linear do crescimento geométrico da largura da cápsula cefálica em função dos ínstares larvais; a equação desta reta é: $Y=0,21+0,288$ X e o Coeficiente de Correlação linear é igual a 0,99 , o que é altamente significativo.

Em A. punctulata, a largura média, em milímetros, das cápsulas cefálicas, a respectiva amplitude e Desvio Padrão, entre parêntesis, do primeiro ao quinto ínstar larval, foi respectivamente: $0,65(0,62$ a 0,$68 ; 0,0190) ; 0,86(0,80$ a 0,$90 ; 0,0333)$; $1,18(1,12$ a 1,$26 ; 0,0432) ; 1,60(1,50$ a 1,$68 ; 0,0681)$ e $2,05(1,92$ a 2,$20 ; 0,1165)$ (Tab. XII). A figuta 79 mostra a Reta de Regresão linear do crescimento geométrico da largura da cápsula cefálica em função dos ínstares larvais; a Equação desta reta é: $Y=0,206+0,354 \mathrm{X}$ e o Coeficiente de Correlação Linear é 0,99 , sendo altamente significativo.

As médias da largura das cápsulas cefálicas dos cinco ínstares larvais das espécies de Anacassis estudadas, diferem entre si significativamente, consideran- 
do-se os ínstares de uma mesma espécie (Tab. XIII); não se observou nenhuma superposição de medidas, mesmo considerando-se o maior valor de um ínstar e o menor valor do ínstar seguinte, o que permite a identificação do ínstar a que uma larva pertence pela medida da largura da cápsula cefálica.

Em A. cribrum, segundo BUZZI (1975a), a largura média e a respectiva amplitude entre parêntesis, em milímetros, das cápsulas cefálicas, do primeiro ao quinto ínstar, foi respectivamente: $0,54(0,52$ a 0,56$) ; 0,76(0,70$ a 0,80$) ; 1,03(0,96$ a 1,12$) ; 1,36(1,26$ a 1,46$)$ e $1,81(1,60$ a 2,00$)$, que se aproximam muito das medidas da largura das cápsulas cefálicas de $A$. phaeopoda.

A tabela XIII, mostra a comparação da largura média das cápsulas cefálicas dos ínstares larvais das espécies de Anacassis estudadas. As médias do primeiro ao terceiro ínstar de A.dubia não diferem das médias de $A$. phaeopoda; as médias de A. fuscata não diferem das de $A$. fuscata (forma) mas diferem das demais espécies, exceto com o último ínstar de $A$. dubia; as médias dos três primeiros ínstares de $A$. languida não diferem das de $A$. punctulata, mas diferem das demais espécies; as médias da largura das cápsulas cefálicas do quarto ínstar de $A$. dubia difere das demais espécies que diferem entre si, exceto A. fuscata e $A$. fuscata (forma); as médias da largura da cápsula cefálica do quinto ínstar de A. dubia, A. fuscata e A. fuscata (forma), não diferem significativamente, mas diferem das demais espécies, cujas médias diferem entre si.

\section{Razão de crescimento}

A razão de crescimento de cada ínstar e a razão média de crescimento durante todo o desenvolvimento larval das espécies de Anacassis estudadas estão na Tab. XIV.

A. dubia apresenta as seguintes razões de crescimento, do primeiro ao quinto ínstar, respectivamente: 1,$34 ; 1,33 ; 1,27 ; 1,24$ e a razão média de crescimento durante todo o desenvolvimento é 1,29 sendo a menor média de crescimento dentre as espécies estudadas na presente pesquisa.

A. fuscata com as seguintes razões de crescimento: 1,39; 1,30;1,33 e 1,36 e a razão média de crescimento durante todo o desenvolvimento é 1,34.

A. fuscata (forma) com as seguintes razões de crescimento: 1,40;1,33; 1,31 e 1,31 e a razão média de crescimento durante todo o desenvolvimento é 1,34 , que se equipara à média de $A$. fuscata sendo as maiores médias de crescimento dentre as espécies estudadas na presente pesquisa.

As razões de crescimento de $A$. fuscata obtidas através dos dados apresentados por BUZZI (1975b) são: 1,37; 1,37; 1,33 e 1,35 e a razão média de crescimento durante todo o desenvolvimento é 1,35 , valores próximos dos obtidos para a mesma espécie na presente pesquisa e as diferenças podem ser atribuídas às condições de criação.

Razões de crescimento de A. languida: 1,30;1,35; 1,30 e 1,24 e a razão média de crescimento durante todo o desenvolvimento é 1,30. As razões de crescimento de A. languida obtidas através dos dados apresentados por BUZZI \& GARCIA (1983) são: 1,$31 ; 1,42 ; 1,24$ e 1,49 e a razão média de crescimento durante todo o desenvolvimento é 1,37 , valores próximos dos obtidos para a mesma espécie na 
presente pesquisa e a diferença certamente é devida às condições de criação.

Razões de crescimento de $A$. phaeopoda: 1,$36 ; 1,32 ; 1,34$ e 1,27 e a razão média de crescimento durante todo o desenvolvimento é igual a 1,32.

Anacassis punctulata com as seguintes razões de crescimento: 1,$31 ; 1,38$; 1,36 e 1,26 e a razão média de crescimento durante todo o desenvolvimento é igual a 1,33 .

DYAR (1890), citado por PARRA (1979), estabeleceu a seguinte regra, conhecida como Lei de DYAR: "A cápsula cefálica das lagartas cresce em progressão geométrica, aumentando em largura a cada ecdise, numa razão constante para uma dada espécie e, em média, 1,4". Observando-se os valores para a razão de crescimento dos ínstares das espécies de Anacassis estudadas, nota-se que a "Lei de Dyar" não se aplica totalmente a estas espécies, pois a largura das cápsulas cefálicas não aumenta numa razão constante e os valores são quase sempre menores do que 1,4, havendo desvios que ficam acima ou abaixo da reta de regressão linear entre a largura da cápsula cefálica em função dos ínstares larvais (Figs 74-79). A razão média de crescimento durante todo o desenvolvimento larval varia de espécie para espécie, só sendo igual entre $A$. fuscata e $A$.fuscata (forma) e muito próxima a de A. phaeopoda.

As razões de crescimento de $A$. cribrum, obtidas através dos dados apresentados por BUZZI (1975a) são, do primeiro ao último ínstar: 1,41; 1,36; 1,32 e 1,33 e a razão média de crescimento durante todo o desenvolvimento é 1,36 , valores que se aproximam dos obtidos para A. fuscata.

\section{Duração dos ínstares e do estágio larval}

A duração, em dias, dos ínstares larvais das larvas de Anacassis estão nas tabelas XVII a XXII.

A duração média, em dias, a respectiva amplitude e Desvio Padrão, entre parêntesis, dos ínstares larvais de $A$. dubia, do primeiro ao quinto ínstar, foi respectivamente: 8,16 (4 a 13; 3,0416); 4,89 (3 a $8 ; 1,5237) ; 4,63$ (3 a $8 ; 1,5438$ ); $4,73$ (3 a $7 ; 1,0328)$ e 7,50 (7 a 9; 1,0919) (Tab. XVII). A média de duração do primeiro ínstar difere significativamente das demais, que não diferem entre si.

A duração média, em dias, a respectiva amplitude e Desvio Padrão, entre parêntesis, dos ínstares larvais de $A$. fuscata, do primeiro ao quinto ínstar, é respectivamente: 4,33 (3 a $6 ; 0,7670) ; 2,67$ (2 a 5; 0,8997); 3,79 (2 a 6; 1,3114); $5,08$ ( 3 a $8 ; 1,6564)$ e $6,40(5$ a $7 ; 0,6992)$ (Tab. XVIII). As médias do segundo e terceiro ínstar não diferem entre si, porém, a do terceiro ínstar, não difere da média do primeiro ínstar que não difere da média do quarto e do quinto ínstares que também não diferem entre si mas diferem do segundo e terceiro ínstares.

A duração média, em dias, a respectiva amplitude e Desvio Padrão, entre parêntesis, dos ínstares larvais de $A$. fuscata (forma), do primeiro ao quinto ínstar, foi respectivamente: 3,45 ( 3 a $4 ; 0,5104) ; 2,55$ ( 2 a $5 ; 0,8256) ; 4,94$ (3 a 8; 1,4349); 3,69 (3 a 5; 0,6304) e 6,69 (5 a 9; 1,3775) (Tab. XIX). A duração média do primeiro e do segundo ínstar não difere entre si; a média do primeiro não difere do quarto ínstar e as médias do terceiro e quinto ínstar diferem siginificativamente entre si e em relação às demais. 
BuZZI (1975b) obteve para a larva de A. fuscata, criada sob temperatura média de $21,9^{\circ} \mathrm{C}$, os seguintes resultados para a duração média, em dias, do primeiro ao quinto ínstar, respectivamente: 3,$1 ; 3,0 ; 2,8 ; 3,1$ e 5,0. Comparando-se esses resultados com os obtidos para A. fuscata e A. fuscata (forma) na presente pesquisa, nota-se que diferem bastante, o que pode ser atribuído às condições de criação.

A duração média, em dias, a respectiva amplitude e Desvio Padrão, entre parêntesis, dos ínstares larvais de $A$. languida, do primeiro ao quinto ínstar foi respectivamente: 5,63 (4 a $8 ; 1,3025) ; 3,25$ (2 a 4; 0,7071); 3,57 (3 a 5; 0,7868); 4,17 (3 a 5; 0,7528) e 9,17 (7 a 11; 1,4720) (Tab. XX). As médias do segundo ao quarto ínstar não diferem entre si; a do quarto ínstar não difere da média do primeiro ínstar e a média do último ínstar difere significativamente de todas as outras médias.

A duração média, em dias, a respectiva amplitude e Desvio Padrão, entre parêntesis, dos ínstares larvais de A. phaeopoda foi do primeiro ao quinto ínstar, respectivamente: 4,22 ( 2 a $7 ; 1,3128) ; 3,40$ ( 2 a $7 ; 1,5355) ; 3,94$ (3 a $7 ; 1,1618) ; 3,38$ (2 a $5 ; 1,0247)$ e $7,56(6$ a $10 ; 1,0308)$ (Tab. XXI). A média do quinto ínstar de $A$. phaeopoda difere significativamente das demais médias que não diferem entre si.

BuzzI (1975a) obteve para a larva de A. cribrum, sob temperaturas médias de 23 e $18^{\circ} \mathrm{C}$, a seguinte duração média, do primeiro ao quinto ínstar, respectivamente: 3,$3 ; 2,9 ; 2,9 ; 4,5 ; 7,5$ e 4,$4 ; 3,4 ; 3,7 ; 4,1 ; 11,1$ dias.

A tabela XXII, mostra a comparação estatística dos ínstares larvais das espécies estudadas de Anacassis exceto A. punctulata.

A média de duração do primeiro ínstar de $A$. dubia difere significativamente das demais médias; as médias de $A$.fuscata e $A$. fuscata (forma) e $A$. phaeopoda não diferem entre si; a média de $A$. languida não difere da média de $A$. phaeopoda e $A$. fuscata mas difere das demais médias. A média de duração do segundo ínstar de $A$. dubia difere significativamente das demais médias, que não diferem entre si. As médias de duração do terceiro e do quarto ínstares não diferem entre si. A média de duração do quinto ínstar de $A$. dubia não difere significativamente das médias de $A$. fuscata, A. fuscata (forma) e A. phaeopoda; a de A. languida não difere de $A$. dubia mas difere significativamente das demais espécies.

A tabela XXIII mostra a duração média do estágio larval das espécies de Anacassis estudadas na presente pesquisa, exceto $A$. punctulata.

A duração média, em dias, do estágio larval, a respectiva amplitude e Desvio Padrão, entre parêntesis, de A. dubia foi 30,36 (23 a 36; 4,0498); de A. fuscata: 21,60 (18 a 27; 3,0623); de A. fuscata (forma): 20,92 (18 a 24; 1,5525); de A. languida: $25,67$ (21 a $28 ; 2,6583)$ e de $A$. phaeopoda: 21,80 (17 a 29; 4,3621). A média de duração do estágio larval de $A$. dubia não difere da média de $A$. languida mas ambas diferem significativamente das demais médias, que não diferem entre si. BuZZI \& GARCIA (1983) obtiveram uma duração de 31,6 dias para o estágio larval de $A$. languida criada em condições de Temperatura que variaram de 20,5 a $22,8^{\circ} \mathrm{C}$; BuzzI (1975b) obteve uma duração de 17 dias para o período larval de A. fuscata, criada sob temperatura de $21,9^{\circ} \mathrm{C}$ e BuZZI (1975a) obteve uma duração do período larval de 21,1 dias para $A$. cribrum a uma temperatura de $23^{\circ} \mathrm{C}$ e 26,7 dias, para uma temperatura de $18^{\circ} \mathrm{C}$. ARAVENA (1960) obteve para A. sulcipennis uma duração de 27 dias, em "condições ambientais". 


\section{Fase prepupal}

A larva de quinto ínstar, antes de empupar, torna-se imóvel, adere-se ao substrato pelos quatro primeiros esternos abdominais e fica sem o anexo exúvio-fecal. A duração das fases de prepupa das espécies de Anacassis estudadas, exceto $A$. punctulata, estão na tabela XXIV. A duração média, em dias, e o Desvio Padrão, entre parêntesis, da fase de prepupa de $A$. dubia, A. fuscata, A. fuscata (forma), $A$. languida e $A$. phaeopoda foram, respectivamente: 1,43 (0,5136); 1,40 (0,5164); $1,25(0,4523) ; 1,67(0,5164)$ e $1,73(0,4577)$. A amplitude de todas as espécies variou de um a dois dias.

BUZZI (1975a e 1975b) e BUZZI \& GARCIA (1983), não mencionam a duração dessa fase para A. cribrum, A. fuscatae A. languida.

\section{Duração do estágio pupal}

A tabela XXV mostra a duração do estágio pupal das espécies de Anacassis estudadas na presente pesquisa.

A duração média, em dias, a respectiva amplitude e Desvio Padrão, entre parêntesis, do estágio pupal de $A$. dubia foi igual a 7,21 (6 a 8; 0,6993); de A. fuscata: 6,00 (4 a 7; 1,0541); de A. fuscata (forma): 5,31 (4 a 6;0,7511); de A. languida: $8,80$ (8 a $11 ; 1,4832)$; de $A$. phaeopoda: $6,20(5$ a $8 ; 0,7746)$ e de $A$. punctulata: $7,40$ (7 a $9 ; 1,1402)$. A média de duração do estágio pupal de $A$. dubia não difere da média de $A$. phaeopoda e de A. punctulata mas difere das demais; as médias de A.fuscata e $A$. fuscata (forma) não diferem da média de $A$. phaeopoda; a média de A. languida e $A$. punctulata não diferem entre si, mas diferem das demais.

ARAVENA (1960) obteve para o estágio pupal de A. sulcipennis, uma duração de três ou quatro dias, "conforme a Temperatura". BuZzi (1975a) obteve para o estágio pupal de $A$. cribrum uma duração de 8,1 dias sob $23^{\circ} \mathrm{C}$ e 11,9 dias sob $18^{\circ} \mathrm{C}$; BuzZI (1975b) obteve para o estágio pupal de A. fuscata uma duração de 8,2 dias, sob $21,9^{\circ} \mathrm{C}$; BUZZI \& GARCIA (1983) obtiveram para o estágio pupal de $A$. languida uma duração de 11,5 dias, sob temperaturas que variaram de 20,5 a $22,8^{\circ} \mathrm{C}$.

\section{Duração do ciclo evolutivo}

A duração média, em dias, a respectiva amplitude e Desvio Padrão, entre parêntesis, conforme tabela XXVI, do ciclo evolutivo das espécies de Anacassis estudadas, exceto $A$. punctulata, foi para $A$. dubia: 48,86 (38 a 54; 5,3039); $A$. fuscata: 33,30 (27 a 40; 4,2177); A. fuscata (forma): 32,23 (28 a 36; 2,0064); $A$. languida: 46,80 (43 a 50;2,8635) e A. phaeopoda: 35,93 (31 a 43; 4,2167). A média de duração do ciclo evolutivo de $A$. dubia não difere da média de $A$. languida, mas ambas diferem significativamente das demais médias, que não diferem entre si.

ARAVENA (1960) obteve para o ciclo evolutivo de A. sulcipennis uma duração de 36 dias; BuZZI (1975a) obteve para A. cribrum uma duração de 40,4 dias a uma tempertura média de $23^{\circ} \mathrm{C}$; o mesmo autor (1975b) obteve para $A$. fuscata uma duração de 34,6 dias sob $21,9^{\circ} \mathrm{C}$ e para $A$. languida, BuZZI \& GARCIA (1983) obtiveram 56,6 dias sob temperaturas que variaram de 20,5 a $22,8^{\circ} \mathrm{C}$. 


\section{CURVAS DE ESPERANÇA DE VIDA}

Os dados e os cálculos referentes às Curvas de Esperança de Vida das espécies de Anacassis estudadas, exceto $A$. punctulata, estão nas tabelas XXVII a XXXI e nas figuras 80 a 84 estão representadas as Curvas de Esperança de Vida.

Anacassis dubia apresenta uma Curva de Esperança de Vida quase uniformemente decrescente com pequeno desvio entre a terceira e quarta idade (Fig. 80).

Anacassis fuscata apresenta uma Curva de Esperança de Vida semelhante a anterior, porém com pequeno desvio entre a segunda e terceira idades (Fig. 81). Anacassis fuscata (forma) apresenta um pequeno aumento na Curva de Esperança de Vida entre a primeira e segunda idade e após segue-se um declive quase uniforme até o final (Fig. 82).

Anacassis languida apresenta uma Curva de Esperança de Vida com declive quase uniforme do início ao fim (Fig. 83).

Anacassis phaeopoda apresenta uma Curva de Esperança de Vida bastante irregular (Fig. 84). Há um aumento na Curva de Esperança de Vida entre a primeira e segunda e um aumento menor entre a quarta e quinta idade e um declive suave entre a segunda e quarta idades e um declive mais acentuado entre a quinta e sexta idade. Comparando-se as Curvas de Esperança de Vida entre si, nota-se que as Curvas de A. dubia, A. fuscata, A. fuscata (forma) e A. languida são semelhantes, enquanto a Curva de Esperança de Vida de $A$. phaeopoda difere das demais espécies.

\section{CURVAS DE SOBREVIVÊNCIA}

A coluna lx das tabelas XXVII a XXXI é conhecida como a Probabilidade de Sobrevivência, pois representa a proporção de indivíduos que estarão vivos numa certa idade em relação ao número inicial. Os valores de lx das espécies de Anacassis estudadas, exceto $A$. punctulata, estão representados nas figuras 85 a 89 que mostram as Curvas de Sobrevivência das referidas espécies desde a idade ovo até a emergência do adulto.

As Curvas de Sobrevivência de A. dubia, A. fuscata, A. fuscata (forma) e $A$. languida se aproximam da Curva do Tipo II, segundo RABINOVICH (1980), isto é, um número relativamente constante de animais morrem nas diferentes idades.

A Curva de Sobrevivência de A. phaeopoda (Fig. 89), se aproxima mais da curva do Tipo IV, que mostra uma mortalidade maior nos indivíduos jovens.

As Curvas de Sobrevivência de A. dubia, A. fuscata, A. fuscata (forma), A. languida não diferem significativamente entre si mas diferem da Curva de Sobrevivência de $A$. phaeopoda.

\section{CONCLUSÕES}

Todas as fases do ciclo evolutivo foram mantidas em laboratório sob temperatura e fotofase constantes, obtendo-se excelentes resultados na criação dos imaturos, com pequena taxa de mortalidade, comprovado através das Curvas de Esperança de Vida e de Sobrevivência.

Os imaturos das espécies de Anacassis estudadas na presente pesquisa são morfologicamente semelhantes entre si e as principais diferenças se referem ao tamanho, coloração e pilosidade. 
Todas as espécies estudadas foram criadas sobre espécies de plantas da família Asteraceae e apresentaram alto grau de especificidade.

Os ovos apresentaram semelhanças quanto à cor, superfície, forma, posição das micrópilas; as principais diferenças estão relacionadas com as medidas de comprimento do córion, do pedúnculo e do maior eixo da placa fixadora e da largura do córion. Os ovos maiores são os de A. punctulata e os menores, de A. fuscata. Os ovos de A. phaeopoda são os únicos postos, isoladamente ou em grupos de dois ou três; nas demais espécies são postos formando massas com número variável de ovos.

O menor período médio de incubação obtido foi de $A$. fuscata (forma), com 6,5 dias e o maior, foi de A. dubia, com 11,11 dias.

As larvas apresentaram dentre outras, as seguintes características em comum: cabeça arredondada e forte depressão a cada lado, logo atrás do clípeo; seis ocelos em cada parietal sobre pequenas elevações subcônicas; labro com chanfro no meio da margem anterior; mandíbulas com cinco dentes, destacando-se dois maiores; maxilas com a mala globosa; tórax com seis pares de escolos e abdômen com oito e no oitavo tergo a furca anal que carrega o anexo exúvio-fecal. As principais diferenças estão relacionadas com a distribuição ou ausência de cerdas e/ou chalazas e a distribuição de manchas pretas ou acinzentadas do tegumento, que geralmente é amarelado.

As larvas das espécies estudadas apresentaram cinco ínstares e a medida da largura da cápsula cefálica permite a identificação, com segurança, do ínstar da larva.

A duração, em dias, dos ínstares larvais das espécies de Anacassis estudadas, variou de 2,55 dias [duração de segundo ínstar de $A$. fuscata (forma)] até o máximo de 9,17 dias (duração do quinto ínstar de $A$. languida). A maior duração média, em dias, do estágio larval foi de $A$. dubia com $30,36 \mathrm{em}$ média, e a menor, foi de $A$. fuscata, com 21,60.

A razão média de crescimento durante todo o desenvolvimento larval varia de espécie para espécie só sendo igual entre $A$. fuscata e $A$. fuscata (forma).

As pupas são dorsalmente convexas e no lado ventral, aplanadas; tegumento em geral liso e amarelado; pronoto, na base mais largo que o mesotórax e encobrindo a cabeça; lados do abdômen com oito pares de escolos e no ápice uma curta furca anal. As principais diferenças estão relacionadas com a distribuição de manchas pretas ou acinzentadas; em A. dubia, aos lados, dorsalmente com faixa castanhoavermelhada. O comprimento médio das pupas machos, não difere entre si, o mesmo ocorrendo com as pupas fêmeas; mas o comprimento médio das pupas, macho e fêmea, da mesma espécie, difere significativamente entre si.

A maior duração média, em dias, do período pupal obtida foi a de $A$. languida, com 8,80 e a menor, foi a de A. fuscata (forma), com 5,31.

A maior duração média, em dias, do ciclo evolutivo (desde a oviposição até a emergência do adulto) foi de $A$.dubia com 48,86 e a menor duração foi de $A$. fuscata (forma) com 32,23.

O estudo comparativo dos imaturos de $A$. fuscata e $A$. fuscata (forma), tanto morfológico como dos parâmetros relativos ao ciclo evolutivo, além de serem 
simpátricas, nos levaram a concluir que se trata de uma mesma espécie e as diferenças constatadas na coloração e na distribuição das cerdas, nada mais são do que variações intra-específicas e portanto A. fuscata unicolor (Burmeister, 1870) é sinônimo novo de $A$. fuscata Klug, 1829. A genitália dos adultos de $A$. fuscata e $A$. fuscata (forma) foram comparadas por H. Cordo, citado por BoLDT (1989), onde afirma não ter achado diferenças consistentes.

\begin{abstract}
AGRADECIMENTOS. Aos Professores do Departamento de Zoologia que me dispensaram das obrigações didáticas durante o ano de 1993, para que pudesse trabalhar sem maiores preocupações na elaboração deste trabalho. Ao Professor Dr. Albino M. Sakakibara pelas fotografias que ilustram este trabalho. Ao Professor Dr. Armando Antunes de Almeida, Professora Danúncia Urban e Professor Dr. Cláudio Barros de Carvalho pela leitura dos originais, críticas e sugestões. À Professora Dra. Sônia M. Noemberg Lázzari pela revisão do abstract. Ao Professor Dr. Pe. Jesus S. Moure e Dr. J.R. Cure que permitiram a utilização de seu programa (ANOTSG.BIO e TATMED.TAX) para as análises estatísticas. Ao Professor Dr. Olaf H.H. Mielke pela revisão e sugestões. Ao Professor Olavo Araújo Guimarães pela identificação das plantas hospedeiras. Ao bolsista de Iniciação Científica Rui de Azevedo Nobre Machado Filho pelo auxílio nas coletas e na criação dos insetos.
\end{abstract}

\title{
REFERÊNCIAS BIBLIOGRÁFICAS
}

ARAvena, R. 1960. Evolución del cásido Anacassis sulcipennis Boh. (Col. Cassid.). Rev. Soc. Entomol. Argentina 22 (1959): 41-46.

BENNET, F.D. 1963. Final report on surveys of the insects attacking Baccharis spp., in the S.E. United States of America and Brazil, 1960-63. Commonwealth Inst. Biol. Contr. Rpt., 27p.

BLACKWELDER, R.E. 1946. Checklist of the Coleopterous insects of Mexico, Central America, The West Indies and South America. Bull. U.S. Nat. Mus. 185 (4): 551-763.

BoHeman, C. 1850. Monografia Cassididarum. Tomus primus. Holmiae, Officina Norstedtiana, 452p.

1854. Monographia Cassididarum. Tomus secundus. Holmiae, Officina Norstedtiana, 506p.

BolDT, P.E. 1989a. Baccharis (Asteraceae). A review of its taxonomy, Phytochemistry, Ecology, Economic Status, Natural enemies and the Potential for its Biological Control in the United States. Temple, The Texas A. \& M. University System, College Station, 32p.

1989b. Host specificity studies of Stolas fuscata for the Biological control of Baccharis salicifolia (R. \& P.) Pers. (Asteraceae). Proc. Entomol. Soc. Wash. 91 (4): 502-508.

Boving, A.G. \& F.C. Craighead. 1931. An illustrated synopsis of the principal larval forms of the ordem Coleoptera. Ent. Americana 11: 1-31.

BuZZI, Z.J. 1975a. Descrição e bionomia de Anacassis cribrum (Klug, 1829). Acta Biol. Paranaense, Curitiba, 4 (1,2): 59-89. 
1975b. Contribuição ao conhecimento da biologia de Anacassis fuscata (Klug, 1829). Rev. Brasil. Biol. 5 (4): 767-774.

. 1976. Uma nova espécie de Anacassis do sul do Brasil. (Coleoptera, Chrysomelidae). Dusenia 9 (3): 107-111.

1988. Biology of neotropical Cassidinae, p.559-580. In: P. JoLIVET; E.

PETITPIERRE \& T.H. HSIAO (Eds). Biology of Chrysomelidae. London, Kluwer Academic Publischers, 615p.

BuzzI, Z.J.\& C. GARCIA. 1983. Immature stages and life cycle of Anacassis languida (Boheman, 1854) (Coleoptera. Chrysomelidae, Cassidinae). Coleopts. Bull. 37 (2): 193-198.

Costa, C.; S.A. VAnin \& S.A. CASARI-ChEN. 1988. Larvas de Coleoptera do

Brasil. São Paulo, Museu de Zoologia da Universidade de São Paulo, 282p.

LIMA, A.M. DA C. 1955. Insetos do Brasil 9, Coleópteros (3). Rio de Janeiro,

Escola Nacional de Agronomia, Série Didática 11, 289p.

MCFADYEN, P. 1987. Host specificity of five Anacassis species (Col., Chrysomelidae) introduced into Australia for the biological control of Baccharis halimifolia. (Compositae). Entomoph. 32: 377-379.

PARRA, J.R.P. 1979. Biologia dos insetos. Piracicaba, Escola Superior de Agricultura "Luiz de Queiroz" (ESALQ), 383p.

Peterson, A. 1960. Larvae of Insects. An introduction to Neartic species. Part II (Coleoptera, Diptera, Neuroptera,Siphonaptera, Mecoptera, Trichoptera). Columbus, Edwards Brothers Inc., 416p.

RABINOVICH, J.E. 1980. Introduccion a la ecologia de poblaciones animales.

México, Com. Ed. Continental, 313p.

SOKAL, R.R. \& F.J. ROHLF. 1981. Biometry: the principles and practice of statistics in biological research. New York, W.H. Freeman, 859p.

SPAETH, F. 1914. Coleopterorum Catalogus 62; Chrysomelidae: 16. Cassidinae. Berlin, W. Junk, 182p.

SPIEGEL, M.R. 1972. Estatística. Rio de Janeiro, Ed. McGraw-Hill do Brasil, 580p. VIEIRA, S. 1981 Introdução à Bioestatística. Rio de Janeiro, Ed. Campus Ltda, $294 p$.

Recebido em 30.XI.1995; aceito em 02.VIII.1996. 
Tabela I. Comprimento médio (X), em milimetros, dos ovos de Anacassis dubia (1), A. fuscata (2), A. fuscata (forma) (3), A. languida (4), A. phaeopoda (5) e A. punctulata (6). Desvio Padrão (s), Amplitude (< e >) e Coeficiente de Variação (CV).

\begin{tabular}{ccccccc}
\hline & 1 & 2 & 3 & 4 & 5 & 6 \\
\hline $\mathrm{N}$ & 10 & 20 & 20 & 10 & 20 & 11 \\
$\mathrm{X}$ & $1,82 \mathrm{c}$ & $1,68 \mathrm{a}$ & $1,72 \mathrm{ab}$ & $2,03 \mathrm{~d}$ & $1,78 \mathrm{bc}$ & $2,24 \mathrm{e}$ \\
$\mathrm{S}$ & 0,0908 & 0,0492 & 0,0282 & 0,0700 & 0,0755 & 0,0894 \\
$<$ & 1,64 & 1,58 & 1,66 & 1,92 & 1,60 & 2,16 \\
$>$ & 1,92 & 1,76 & 1,78 & 2,12 & 1,94 & 2,40 \\
$\mathrm{CV}$ & 5,00 & 2,93 & 1,64 & 3,44 & 4,25 & 3,99 \\
\hline
\end{tabular}

*. Médias seguidas de letras iguais não diferem entre si e as seguidas de letras diferentes diferem significativamente ao nivel de $\mathrm{P}=0,05$.

Tabela II. Largura média (X), em milimetros, dos ovos de Anacassis dubia (1), A. fuscata (2), A. fuscata (forma) (3), A. languida (4), A. phaeopoda (5) e A. punctulata (6). Desvio Padrão (s). Amplitude (<e >) e Coeficiente de Variação (CV).

\begin{tabular}{ccccccc}
\hline & 1 & 2 & 3 & 4 & 5 & 6 \\
\hline $\mathrm{N}$ & 10 & 20 & 20 & 10 & 20 & 11 \\
$\mathrm{X}$ & $0,78 \mathrm{bc}$ & $0,71 \mathrm{a}$ & $0,74 \mathrm{ab}$ & $0,90 \mathrm{~d}$ & $0,82 \mathrm{c}$ & $0,93 \mathrm{~d}$ \\
$\mathrm{~s}$ & 0,0285 & 0,0470 & 0,0672 & 0,0398 & 0,0326 & 0,0300 \\
$<$ & 0,73 & 0,60 & 0,68 & 0,82 & 0,74 & 0,92 \\
$>$ & 0,82 & 0,78 & 0,94 & 0,96 & 0,86 & 0,96 \\
$\mathrm{CV}$ & 3,65 & 6,62 & 9,04 & 4,40 & 3,96 & 3,24
\end{tabular}

*. Médias seguidas de letras iguais não diferem entre si e as seguidas de letras diferentes diferem significativamente ao nivel de $\mathrm{P}=0,05$.

Tabela III. Comprimento médio do pedúnculo (X), em milimetros, dos ovos de Anacassis dubia (1) A. fuscata (2), A. fuscata (forma) (3), A. languida (4), A. phaeopoda (5), e A. punctulata (6). Desvio Padrão (s). Amplitude (<e >) e Coeficiente de Variação (CV).

\begin{tabular}{ccccccc}
\hline & 1 & 2 & 3 & 4 & 5 & 6 \\
\hline $\mathrm{N}$ & 10 & 10 & 11 & 6 & 10 & 10 \\
$\mathrm{X}$ & $0,70 \mathrm{~b}$ & $0,14 \mathrm{a}$ & $0,37 \mathrm{a}$ & $0,81 \mathrm{~b}$ & $0,35 \mathrm{a}$ & $0,96 \mathrm{~b}$ \\
$\mathrm{~S}$ & 0,3098 & 0,0764 & 0,1135 & 0,4366 & 0,1562 & 0,1199 \\
$<$ & 0,33 & 0,02 & 0,20 & 0,90 & 0,10 & 0,80 \\
$>$ & 1,30 & 0,26 & 0,60 & 1,52 & 0,60 & 1,20 \\
$\mathrm{CV}$ & 44,44 & 54,16 & 30,31 & 54,13 & 44,51 & 12,54 \\
\hline
\end{tabular}

*. Médias seguidas de letras iguais não diferem entre si e as seguidas de letras diferentes diferem significativamente ao nível de $\mathrm{P}=0,05$. 
Tabela IV. Comprimento médio do eixo maior da placa fixadora (X), em milimetros, dos ovos de Anacassis dubia (1), A. fuscata (2) A. fuscata (forma) (3), A. languida (4), A. phaeopoda (5) e A. punctulata (6). Desvio Padrão (s),Amplitude (<e >) e Coeficiente de Variação (CV).

\begin{tabular}{ccccccc} 
& 1 & 2 & 3 & 4 & 5 & 6 \\
\hline $\mathrm{N}$ & 10 & 10 & 11 & 6 & 10 & 10 \\
$\mathrm{X}$ & $0,85 \mathrm{ab}$ & $0,76 \mathrm{a}$ & $0,78 \mathrm{a}$ & $0,90 \mathrm{ab}$ & $1,05 \mathrm{~b}$ & $0,95 \mathrm{ab}$ \\
$\mathrm{s}$ & 0,1473 & 0,0665 & 0,0870 & 0,2860 & 0,1003 & 0,2572 \\
$<$ & 0,65 & 0,66 & 0,60 & 0,48 & 0,90 & 0,60 \\
$>$ & 1,17 & 0,86 & 0,90 & 1,25 & 1,24 & 1,40 \\
$\mathrm{CV}$ & 17,37 & 8,71 & 11,14 & 31,83 & 9,54 & 27,04 \\
\hline
\end{tabular}

*. Médias seguidas de letras iguais não diferem entre si e as seguidas de letras diferentes diferem significativamente ao nível de $\mathrm{P}=0,05$.

Tabela V. Número médio (X) de ovos por posturade Anacassis dubia (1), A. fuscata (2), A. fuscata (forma) (3). Desvio Padrão (s). Amplitude (< e >) e Coeficiente de Variação (CV).

\begin{tabular}{cccc}
\hline & 1 & 2 & 3 \\
\hline$N$ & 6 & 13 & 14 \\
$X$ & $9,17 \mathrm{a}$ & $12,54 \mathrm{ab}$ & $14,29 \mathrm{~b}$ \\
$\mathrm{~S}$ & 1,3229 & 3,6882 & 2,6144 \\
$<$ & 7 & 5 & 8 \\
$>$ & 10 & 18 & 18 \\
CV & 14,43 & 29,41 & 18,30
\end{tabular}

*. Médias seguidas de letras iguais não diferem entre si e as seguidas de letras diferentes diferem significativamente ao nível de $\mathrm{P}=0,05$.

Tabela VI. Duração média (X), em dias, do periodo deincubação dos ovos de Anacassis dubia (1), A. fuscata (2), A. fuscata (forma) (3), A. languida (4), A. phaeopoda (5). Desvio Padrão (s), Amplitude (<e >) e Coeficiente de Variação (CV). Temperatura $25 \pm 2^{\circ} \mathrm{C}$, fotofase $12 \mathrm{~h}$, U.R. $85 \pm 5 \%$.

\begin{tabular}{cccccc}
\hline & 1 & 2 & 3 & 4 & 5 \\
\hline $\mathrm{N}$ & 19 & 18 & 20 & 6 & 23 \\
$\mathrm{X}$ & $11,11 \mathrm{c}$ & $6,22 \mathrm{a}$ & $6,15 \mathrm{a}$ & $12,67 \mathrm{~d}$ & $7,96 \mathrm{~b}$ \\
$\mathrm{~s}$ & 1,4489 & 1,4371 & 0,3663 & 0,8165 & 0,6381 \\
$<$ & 9 & 3 & 6 & 12 & 7 \\
$>$ & 13 & 8 & 7 & 14 & 9 \\
$\mathrm{CV}$ & 13,05 & 23,10 & 5,93 & 6,45 & 8,02 \\
\hline
\end{tabular}

*. Médias seguidas de letras iguais não diferem entre si e as seguidas de letras diferentes diferem significativamente ao nivel de $\mathrm{P}=0,05$. 
Tabela VII. Largura média (X), em milimetros, das cápsulas cefálicas dos ínstares larvais (I a V) de Anacassis dubia. Desvio Padrão (s), Amplitude (<e $>$ ) e Coeficiente de Variação (CV).

\begin{tabular}{cccccc}
\hline & I & II & III & IV & V \\
\hline $\mathrm{N}$ & 15 & 15 & 15 & 15 & 11 \\
$\mathrm{X}$ & $0,56 \mathrm{a}$ & $0,76 \mathrm{~b}$ & $0,99 \mathrm{c}$ & $1,25 \mathrm{~d}$ & $1,54 \mathrm{e}$ \\
$\mathrm{s}$ & 0,0241 & 0,0229 & 0,0345 & 0,0405 & 0,0767 \\
$<$ & 0,52 & 0,72 & 0,94 & 1,18 & 1,44 \\
$>$ & 0,60 & 0,80 & 1,04 & 1,32 & 1,68 \\
$\mathrm{CV}$ & 4,28 & 3,03 & 3,49 & 3,23 & 4,97 \\
\hline
\end{tabular}

*. Médias seguidas de letras iguais não diferem entre si e as seguidas de letras diferentes diferem significativamente ao nivel de $\mathrm{P}=0,05$.

Tabela VIII. Largura média (X), em milímetros, das cápsulas cefálicas dos ínstares larvais (I a V) de Anacassis fuscata. Desvio Padrão (s), Amplitude (< e >) e Coeficiente de Variação (CV).

\begin{tabular}{cccccc}
\hline & I & II & III & IV & V \\
\hline $\mathrm{N}$ & 15 & 15 & 15 & 15 & 10 \\
$\mathrm{X}$ & $0,48 \mathrm{a}$ & $0,67 \mathrm{~b}$ & $0,87 \mathrm{c}$ & $1,15 \mathrm{~d}$ & $1,58 \mathrm{e}$ \\
$\mathrm{s}$ & 0,0141 & 0,0195 & 0,0301 & 0,0578 & 0,0636 \\
$<$ & 0,46 & 0,64 & 0,82 & 1,06 & 1,50 \\
$>$ & 0,50 & 0,70 & 0,90 & 1,28 & 1,73 \\
$\mathrm{CV}$ & 2,92 & 2,93 & 3,46 & 5,01 & 4,03 \\
\hline
\end{tabular}

*. Médias seguidas de letras iguais não diferem entre si e as seguidas de letras diferentes diferem significativamente ao nível de $\mathrm{P}=0,05$.

Tabela IX. Largura média (X), em milimetros, das cápsulas cefálicas dos ínstares larvais (I a V) de Anacassis fuscata (forma). Desvio Padrão (s), Amplitude ( $<$ e $>$ ) e Coeficiente de Variação CV).

\begin{tabular}{cccccc}
\hline & I & II & III & IV & V \\
\hline $\mathrm{N}$ & 13 & 13 & 11 & 11 & 11 \\
$\mathrm{X}$ & $0,48 \mathrm{a}$ & $0,67 \mathrm{~b}$ & $0,89 \mathrm{c}$ & $1,17 \mathrm{~d}$ & $1,54 \mathrm{e}$ \\
$\mathrm{s}$ & 0,0172 & 0,0222 & 0,0257 & 0,0509 & 0,0779 \\
$<$ & 0,46 & 0,64 & 0,82 & 1,06 & 1,50 \\
$>$ & 0,50 & 0,70 & 0,90 & 1,28 & 1,73 \\
$\mathrm{CV}$ & 3,58 & 3,29 & 2,88 & 4,35 & 5,07
\end{tabular}

*. Médias seguidas de letras iguais não diferem entre si e as seguidas de letras diferentes diferem significativamente ao nível de $\mathrm{P}=0,05$. 
Tabela $X$. Largura média $(X)$, em milímetros, das cápsulas cefálicas dos ínstares larvais (I a V) de Anacassis lanquida. Desvio Padrão (s), Amplitude (<e $>$ ) eCoeficiente de Variação (CV).

\begin{tabular}{cccccc}
\hline & I & II & III & IV & V \\
\hline $\mathrm{N}$ & 8 & 8 & 8 & 8 & 6 \\
$\mathrm{X}$ & $0,65 \mathrm{a}$ & $0,84 \mathrm{~b}$ & $1,13 \mathrm{c}$ & $1,47 \mathrm{~d}$ & $1,83 \mathrm{e}$ \\
$\mathrm{s}$ & 0,0267 & 0,0287 & 0,0376 & 0,0802 & 0,1053 \\
$<$ & 0,62 & 0,80 & 1,08 & 1,36 & 1,70 \\
$>$ & 0,70 & 0,87 & 1,20 & 1,58 & 1,99 \\
$\mathrm{CV}$ & 4,13 & 3,42 & 3,32 & 5,44 & 5,75 \\
\hline
\end{tabular}

*. Médias seguidas de letras iguais não diferem entre si e as seguidas de letras diferentes diferem significativamente ao nivel de $\mathrm{P}=0,05$.

Tabela XI. Largura média (X), em milimetros,das cápsulas cefálicas dos ínstares larvais (I a V) de Anacassis phaeopoda. Desvio Padrão (s), Amplitude (<e >) eCoeficiente de Variação (CV).

\begin{tabular}{cccccc}
\hline & I & II & III & IV & V \\
\hline $\mathrm{N}$ & 15 & 15 & 15 & 15 & 12 \\
$\mathrm{X}$ & $0,56 \mathrm{a}$ & $0,76 \mathrm{~b}$ & $1,00 \mathrm{c}$ & $1,34 \mathrm{~d}$ & $1,71 \mathrm{e}$ \\
$\mathrm{s}$ & 0,0275 & 0,0172 & 0,0448 & 0,0565 & 0,0399 \\
$<$ & 0,50 & 0,72 & 0,94 & 1,28 & 1,65 \\
$>$ & 0,58 & 0,78 & 1,08 & 1,36 & 1,75 \\
$\mathrm{CV}$ & 4,94 & 2,28 & 4,50 & 4,22 & 2,34 \\
\hline
\end{tabular}

*. Médias seguidas de letras iguais não diferem entre si e as seguidas de letras diferentes diferem significativamente ao nivel de $\mathrm{P}=0,05$.

Tabela XII. Largura média (X),em milimetros, das cápsulas cefálicas dos ínstares larvais (I a V) de Anacassis punctulata. Desvio Padrão (s), Amplitude $(<\mathrm{e}\rangle$ ) eCoeficiente de Variação (CV).

\begin{tabular}{cccccc}
\hline & I & II & III & IV & V \\
\hline $\mathrm{N}$ & 10 & 10 & 10 & 10 & 5 \\
$\mathrm{X}$ & $0,65 \mathrm{a}$ & $0,86 \mathrm{~b}$ & $1,18 \mathrm{c}$ & $1,60 \mathrm{~d}$ & $2,05 \mathrm{e}$ \\
$\mathrm{s}$ & 0,0190 & 0,0333 & 0,0432 & 0,0681 & 0,1165 \\
$<$ & 0,62 & 0,80 & 1,12 & 1,50 & 1,92 \\
$>$ & 0,68 & 0,90 & 1,26 & 1,68 & 2,20 \\
$\mathrm{CV}$ & 2,90 & 3,88 & 3,66 & 4,26 & 5,67
\end{tabular}

*. Médias seguidas de letras iguais não diferem entre si e as seguidas de letras diferentes diferem significativamente ao nivel de $\mathrm{P}=0,05$. 
Tabela XIII. Largura média, em milimetros, das cápsulas cefálicas dos instares larvais (I-V) de Anacassis dubia (1), A. fuscata (2), A. fuscata (forma) (3), A. languida (4), A. phaeopoda (5) e A. punctulata (6).

\begin{tabular}{ccccccc}
\hline Ínstar & 1 & 2 & 3 & 4 & 5 & 6 \\
\hline I & $0,56 \mathrm{~b}$ & $0,48 \mathrm{a}$ & $0,48 \mathrm{a}$ & $0,65 \mathrm{c}$ & $0,56 \mathrm{~b}$ & $0,65 \mathrm{c}$ \\
II & $0,76 \mathrm{e}$ & $0,67 \mathrm{~d}$ & $0,67 \mathrm{~d}$ & $0,84 \mathrm{f}$ & $0,76 \mathrm{e}$ & $0,86 \mathrm{f}$ \\
III & $0,99 \mathrm{~h}$ & $0,87 \mathrm{~g}$ & $0,89 \mathrm{~g}$ & $1,13 \mathrm{i}$ & $1,00 \mathrm{~h}$ & $1,18 \mathrm{i}$ \\
IV & $1,25 \mathrm{k}$ & $1,15 \mathrm{j}$ & $1,17 \mathrm{j}$ & $1,47 \mathrm{~m}$ & $1,34 \mathrm{I}$ & $1,60 \mathrm{n}$ \\
V & $1,54 \mathrm{t}$ & $1,58 \mathrm{t}$ & $1,54 \mathrm{t}$ & $1,83 \mathrm{q}$ & $1,71 \mathrm{p}$ & $2,05 \mathrm{r}$ \\
\hline
\end{tabular}

*. Médias seguidas de letras iguais não diferem entre si e as seguidas de letras diferentes diferem significativamente ao nivel de $\mathrm{P}=0,05$, considerando-se as linhas e as colunas.

Tabela XIV. Razão de crescimento de cada ínstar $(R C)$ e a razão média de crescimento (RX) durante todoo desenvolvimento larval de Anacassis dubia (1), A. fuscata (2), A. fuscata (forma) (3), A. lanquida (4), A. phaeopoda (5) e A. punctulata (6). Desvio Padrão (s).

\begin{tabular}{|c|c|c|c|c|c|c|c|}
\hline & & 1 & 2 & 3 & 4 & 5 & 6 \\
\hline \multicolumn{8}{|l|}{1} \\
\hline & $\mathrm{RC}$ & 1,34 & 1,39 & 1,40 & 1,30 & 1,36 & 1,31 \\
\hline & $\mathrm{s}$ & 0,6180 & 0,0626 & 0,0355 & 0,0773 & 0,0533 & 0,0603 \\
\hline \multicolumn{8}{|c|}{ II } \\
\hline & $\begin{array}{c}\mathrm{RC} \\
\mathrm{s}\end{array}$ & $\begin{array}{c}1,33 \\
0,0961\end{array}$ & $\begin{array}{c}1,30 \\
0.0559\end{array}$ & $\begin{array}{c}1,33 \\
0,0335\end{array}$ & $\begin{array}{c}1,35 \\
0,0747\end{array}$ & $\begin{array}{c}1,32 \\
0,0455\end{array}$ & $\begin{array}{c}1,38 \\
0,0618\end{array}$ \\
\hline \multicolumn{8}{|l|}{ III } \\
\hline & $\mathrm{RC}$ & 1,27 & 1,33 & 1,31 & 1,30 & 1,34 & 1,36 \\
\hline & $\mathrm{s}$ & 0,0645 & 0,624 & 0,0333 & 0,0369 & 0,0376 & 0,0627 \\
\hline \multicolumn{8}{|c|}{ IV } \\
\hline & $\mathrm{RC}$ & 1,24 & 1,36 & 1,31 & 1,24 & 1,27 & 1,26 \\
\hline & $\mathrm{s}$ & 0,0395 & 0,0778 & 0,0507 & 0,0648 & 0,0661 & 0,0533 \\
\hline \multicolumn{8}{|l|}{ V } \\
\hline & $\mathrm{RX}$ & 1,29 & 1,34 & 1,34 & 1,30 & 1,32 & 1,33 \\
\hline
\end{tabular}


Tabela XV. Comprimento médio (X), em milimetros, de pupas machos e fêmeas, de Anacassis dubia (1), A. fuscata (2), A.f uscata (forma) (3), e A. phaeopoda (4). Desvio Padrão (s), Amplitude $(<e>)$ e Coeficiente de Variação (CV).

\begin{tabular}{|c|c|c|c|c|c|c|}
\hline & \multicolumn{2}{|r|}{1} & 2 & \multicolumn{2}{|l|}{3} & 4 \\
\hline \multicolumn{7}{|c|}{ Machos } \\
\hline $\mathrm{N}$ & \multicolumn{2}{|r|}{9} & 11 & \multicolumn{2}{|l|}{20} & 5 \\
\hline$x$ & \multicolumn{2}{|r|}{$7,34 a$} & $7,57 a$ & \multicolumn{2}{|l|}{$7,37 a$} & $7,80 a$ \\
\hline $\mathrm{s}$ & \multicolumn{2}{|r|}{0,2922} & 0,3361 & \multicolumn{2}{|l|}{0,1052} & 0,1343 \\
\hline$<$ & \multicolumn{2}{|r|}{6,92} & 7,08 & \multicolumn{2}{|l|}{6,17} & 7,60 \\
\hline$>$ & \multicolumn{2}{|r|}{7,67} & 8,33 & \multicolumn{2}{|l|}{8,00} & 7,92 \\
\hline $\mathrm{CV}$ & \multicolumn{2}{|r|}{3,98} & 4,44 & \multicolumn{2}{|l|}{6,39} & 1,72 \\
\hline \multicolumn{7}{|c|}{ Fêmeas } \\
\hline $\mathrm{N}$ & \multicolumn{2}{|r|}{8} & 6 & \multicolumn{2}{|l|}{11} & 8 \\
\hline$x$ & \multicolumn{2}{|r|}{$8,34 b$} & $8,43 b$ & \multicolumn{2}{|l|}{$8,07 b$} & $8,50 b$ \\
\hline $\mathrm{s}$ & \multicolumn{2}{|r|}{0,6258} & 0,2121 & \multicolumn{2}{|l|}{0,3559} & 0,2814 \\
\hline$<$ & \multicolumn{2}{|r|}{7,58} & 8,25 & \multicolumn{2}{|l|}{7,33} & 8,17 \\
\hline$>$ & \multicolumn{2}{|r|}{9,67} & 8,83 & \multicolumn{2}{|l|}{8,75} & 9,00 \\
\hline CV & \multicolumn{2}{|r|}{7,50} & 2,51 & \multicolumn{2}{|l|}{4,41} & 3,31 \\
\hline \multirow{2}{*}{\multicolumn{7}{|c|}{$\begin{array}{l}\text { *. Médias seguidas de letras iguais não diferem entre si e as seguidas de letras diferentes } \\
\text { diferem significativamente ao nível de } \mathrm{P}=0,05 \text {, considerando-se linhas e colunas.. } \\
\text { Tabela XVI. Comprimento médio (X), em milimetros, das pupas de Anacassis dubia (1), A } \\
\text { fuscata (2), A. fuscata (forma) (3), A. languida (4), A. phaeopoda (5) e A. punctulata (6). Desvio } \\
\text { Padrão (s), Amplitude (<e >) e Coeficiente de Variação (CV). }\end{array}$}} \\
\hline & & & & & & \\
\hline & 1 & 2 & 3 & 4 & 5 & 6 \\
\hline $\mathrm{N}$ & 18 & 16 & 31 & 5 & 13 & 5 \\
\hline$x$ & $7,84 a b$ & $7,89 a b$ & $7,62 a$ & $9,52 \mathrm{c}$ & $8,23 b$ & $10,83 d$ \\
\hline s & 0,7015 & 0,5299 & 0,5474 & 0,1304 & 0,4195 & 0,2641 \\
\hline$<$ & 6,92 & 7,08 & 6,17 & 9,40 & 7,60 & 10,50 \\
\hline$>$ & 9,67 & 8,83 & 8,75 & 9,70 & 9,00 & 11,17 \\
\hline CV & 8,95 & 6,72 & 7,19 & 1,37 & 5,10 & 2,44 \\
\hline
\end{tabular}

*. Médias seguidas de letras iguais não diferem entre si e as seguidas de letras diferentes diferem significativamente ao nível de $\mathrm{P}=0,05$. 
Tabela XVII. Duração média, em dias, dos instares larvais (I a V) de Anacassis dubia. Desvio Padrão (s), Amplitude (<e $>$ ) e Coeficiente de Variação (CV). Temperatura $25 \pm 2^{\circ} \mathrm{C}$, fotofase 12 h, U.R. $85 \pm 5 \%$.

\begin{tabular}{cccccc}
\hline & I & II & III & IV & V \\
\hline $\mathrm{N}$ & 19 & 19 & 16 & 15 & 14 \\
$\mathrm{X}$ & $8,16 \mathrm{~b}$ & $4,89 \mathrm{a}$ & $4,63 \mathrm{a}$ & $4,73 \mathrm{a}$ & $7,50 \mathrm{a}$ \\
$\mathrm{S}$ & 3,0416 & 1,5237 & 1,5438 & 1,0328 & 1,0919 \\
$<$ & 4 & 3 & 3 & 3 & 7 \\
$>$ & 13 & 8 & 8 & 7 & 9 \\
$\mathrm{CV}$ & 37,28 & 31,13 & 33,38 & 21,82 & 14,56
\end{tabular}

*. Médias seguidas de letras iguais não diferem entre si e as seguidas de letras diferentes diferem significativamente ao nível de $\mathrm{P}=0,05$.

Tabela XVIII. Duração média, em dias, dos instareslarvais (I a V) de Anacassis fuscata. Desvio Padrão (s), Amplitude ( $<$ e $>$ ) e Coeficiente de Variação (CV). Temperatura $25 \pm 2^{\circ} \mathrm{C}$, fotofase 12 h, U.R. $85 \pm 5 \%$.

\begin{tabular}{cccccc}
\hline & I & II & III & IV & V \\
\hline $\mathrm{N}$ & 18 & 15 & 14 & 13 & 10 \\
$\mathrm{X}$ & $4,33 \mathrm{bc}$ & $2,67 \mathrm{a}$ & $3,79 \mathrm{ab}$ & $5,08 \mathrm{c}$ & $6,40 \mathrm{c}$ \\
$\mathrm{S}$ & 0,7670 & 0,8997 & 1,3114 & 1,6564 & 0,6992 \\
$<$ & 3 & 2 & 2 & 3 & 5 \\
$>$ & 6 & 5 & 6 & 8 & 7 \\
$\mathrm{CV}$ & 17,70 & 33,74 & 34,64 & 32,63 & 10,93 \\
\hline
\end{tabular}

*. Médias seguidas de letras iguais não diferem entre si e as seguidas de letras diferentes diferem significativamente ao nivel de $\mathrm{P}=0,05$.

Tabela XIX. Duração média, em dias, dos instares larvais ( $\mathrm{a}$ V) de Anacassis fuscata (forma). Desvio Padrão (s), Amplitude (<e >) e Coeficiente de Variação (CV). Temeperatura $25 \pm 2^{\circ} \mathrm{C}$, fotofase 12 h; U.R. $85 \pm 5 \%$.

\begin{tabular}{cccccc}
\hline & I & II & III & IV & V \\
\hline N & 20 & 20 & 17 & 13 & 13 \\
X & $3,45 a b$ & $2,55 a$ & $4,94 c$ & $3,69 \mathrm{~b}$ & $6,69 \mathrm{~d}$ \\
$\mathrm{~S}$ & 0,5104 & 0,8256 & 1,4349 & 0,6304 & 1,3775 \\
$<$ & 3 & 2 & 3 & 3 & 5 \\
$>$ & 4 & 5 & 8 & 5 & 9 \\
$\mathrm{CV}$ & 14,79 & 32,38 & 29,04 & 17,07 & 20,58
\end{tabular}

*. Médias seguidas de letras iguais não diferem entre si e as seguidas de letras diferentes diferem significativamente ao nivel de $\mathrm{P}=0,05$. 
Tabela XX. Duração média, em dias, dos ínstares larvais ( I a V) de Anacassis languida. Desvio Padrão (s), Amplitude (<e >) e Coeficiente de Variação (CV). Temperatura $25 \pm 2^{\circ} \mathrm{C}$, fotofase 12 h. U.R. $85 \pm 5 \%$.

\begin{tabular}{cccccc}
\hline & I & II & III & IV & V \\
\hline N & 8 & 8 & 7 & 6 & 6 \\
X & $5,63 b$ & $3,25 a$ & $3,57 a$ & $4,17 a b$ & $9,17 \mathrm{c}$ \\
$\mathrm{S}$ & 1,3025 & 0,7071 & 0,7868 & 0,7528 & 1,4720 \\
$<$ & 4 & 2 & 3 & 3 & 7 \\
$>$ & 8 & 4 & 5 & 5 & 11 \\
CV & 23,16 & 21,76 & 22,03 & 18,07 & 16,06 \\
\hline
\end{tabular}

*. Médias seguidas de letras iguais não diferem entre si e as seguidas de letras diferentes diferem significativamente ao nivel de $\mathrm{P}=0,05$.

Tabela XXI. Duração média, em dias, dos ínstares larvais (I a V) de Anacassis phaeopoda. Desvio Padrão (s), Amplitude (<e >) e Coeficiente de Variação (CV). Temperatura $25 \pm 2^{\circ} \mathrm{C}$, fotofase 12 h, U.R. $85 \pm 5 \%$.

\begin{tabular}{cccccc}
\hline & I & II & III & IV & V \\
\hline $\mathrm{N}$ & 23 & 20 & 18 & 16 & 16 \\
$\mathrm{X}$ & $4,22 \mathrm{a}$ & $3,40 \mathrm{a}$ & $3,94 \mathrm{a}$ & $3,38 \mathrm{a}$ & $7,56 \mathrm{~b}$ \\
$\mathrm{~S}$ & 1,3128 & 1,5355 & 1,1618 & 1,0247 & 1,0308 \\
$<$ & 2 & 2 & 3 & 2 & 6 \\
$>$ & 7 & 7 & 7 & 5 & 10 \\
$\mathrm{CV}$ & 31,13 & 45,16 & 29,45 & 30,36 & 13,63 \\
\hline
\end{tabular}

*. Médias seguidas de letras iguais não diferem entre si e as seguidas de letras diferentes diferem significativamente ao nivel de $\mathrm{P}=0,05$.

Tabela XXII. Duração média, em dias, dos instares larvais (I a V) de Anacassis dubia (1), $A$. fuscata (2), A. fuscata (forma) (3), A. languida (4) e A. phaeopoda (5). Temperatura $25 \pm 2^{\circ} \mathrm{C}$, fotofase 12 h, U.R. $85 \pm 5 \%$.

\begin{tabular}{crrrrl}
\hline Ínstar & 1 & 2 & 3 & 4 & \multicolumn{1}{c}{5} \\
\hline I & $8,16 \mathrm{c}$ & $4,33 \mathrm{ab}$ & $3,45 \mathrm{a}$ & $5,63 \mathrm{~b}$ & $4,22 \mathrm{ab}$ \\
II & $4,89 \mathrm{~b}$ & $2,67 \mathrm{a}$ & $2,55 \mathrm{a}$ & $3,25 \mathrm{a}$ & $3,40 \mathrm{a}$ \\
III & $4,63 \mathrm{a}$ & $3,79 \mathrm{a}$ & $4,94 \mathrm{a}$ & $3,57 \mathrm{a}$ & $3,94 \mathrm{a}$ \\
IV & $4,73 \mathrm{a}$ & $5,08 \mathrm{a}$ & $6,69 \mathrm{a}$ & $4,17 \mathrm{a}$ & $3,38 \mathrm{a}$ \\
V & $7,71 \mathrm{ab}$ & $6,40 \mathrm{a}$ & $6,69 \mathrm{a}$ & $9,17 \mathrm{~b}$ & $7,56 \mathrm{a}$ \\
\hline
\end{tabular}

*. Médias seguidas de letras iguais não diferem entre si e as seguidas de letras diferentes diferem significativamente ao nivel de $\mathrm{P}=0,05$, considerando-se somente as linhas. 
Tabela XXIII. Duração média (X), em dias, do estágio larval de Anacassis dubia (1), A. fuscata (2), A. fuscata (forma) (3), A. languida (4) e A. phaeopoda (5). Desvio Padrão (s), Amplitude $(<$ e $\rangle)$ e Coeficiente de Variaçăo (CV). Temperatura $25 \pm 2^{\circ} \mathrm{C}$, fotofase 12 h, U.R. $85 \pm 5 \%$.

\begin{tabular}{cccccc}
\hline & 1 & 2 & 3 & 4 & 5 \\
\hline $\mathrm{N}$ & 14 & 10 & 13 & 6 & 15 \\
$\mathrm{X}$ & $30,36 \mathrm{~b}$ & $21,60 \mathrm{a}$ & $20,92 \mathrm{a}$ & $25,67 \mathrm{ab}$ & $21,80 \mathrm{a}$ \\
$\mathrm{S}$ & 4,0498 & 3,0623 & 1,5525 & 2,6583 & 4,3621 \\
$<$ & 23 & 18 & 18 & 21 & 17 \\
$>$ & 36 & 27 & 24 & 28 & 29 \\
$\mathrm{CV}$ & 13,33 & 14,18 & 7,42 & 10,36 & 20,01 \\
\hline
\end{tabular}

*. Médias seguidas de letras iguais não diferem entre si e as seguidas de letras diferentes diferem significativamente ao nivel de $\mathrm{P}=0,05$.

Tabela XXIV. Duração média, em dias, da fase de pré-pupa de Anacassis dubia (1), A. fuscata (2), A. fuscata (forma) (3), A. languida (4) e A. phaeopoda (5). Desvio Padrão (s), Amplitude $\left(<\right.$ e $>$ ) e Coeficiente de Variação (CV). Temperatura $25 \pm 2^{\circ} \mathrm{C}$, fotofase $12 \mathrm{~h}$, U.R. $85 \pm 5 \%$.

\begin{tabular}{cccccc}
\hline & 1 & 2 & 3 & 4 & 5 \\
\hline $\mathrm{N}$ & 14 & 10 & 12 & 6 & 15 \\
$\mathrm{X}$ & $1,43 \mathrm{a}$ & $1,40 \mathrm{a}$ & $1,25 \mathrm{a}$ & $1,67 \mathrm{a}$ & $1,73 \mathrm{a}$ \\
$\mathrm{S}$ & 0,5136 & 0,5164 & 0,4523 & 0,5164 & 0,4577 \\
$<$ & 1 & 1 & 1 & 1 & 1 \\
$>$ & 2 & 2 & 2 & 2 & 2 \\
$\mathrm{CV}$ & 35,95 & 36,89 & 36,18 & 30,98 & 26,41 \\
\hline
\end{tabular}

*. Médias seguidas de letras iguais não diferem entre si e as seguidas de letras diferentes diferem significativamente ao nivel de $\mathrm{P}=0,05$.

Tabela XXV. Duração média (X), em dias, do estágio pupal de Anacassis dubia (1), $A$. fuscata (2), A. fuscata (forma) (3), A. languida (4), A. phaeopoda (5) e A. punctulata (6). Desvio Padrão (s), Amplitude $\left(<e>\right.$ ) e Coeficiente de Variação (CV). Temperatura $25 \pm 2^{\circ} \mathrm{C}$, fotofase $12 \mathrm{~h}, \mathrm{U} . \mathrm{R}$. $85 \pm 5 \%$.

\begin{tabular}{ccccccc}
\hline & 1 & 2 & 3 & 4 & 5 & 6 \\
\hline $\mathrm{N}$ & 14 & 10 & 13 & 5 & 15 & 5 \\
$\mathrm{X}$ & $7,21 \mathrm{~b}$ & $6,00 \mathrm{a}$ & $5,31 \mathrm{a}$ & $8,80 \mathrm{c}$ & $6,20 \mathrm{ab}$ & $7,40 \mathrm{bc}$ \\
$\mathrm{S}$ & 0,6993 & 1,0541 & 0,7511 & 1,4832 & 0,7746 & 1,1402 \\
$<$ & 6 & 4 & 4 & 8 & 5 & 7 \\
$>$ & 8 & 7 & 6 & 11 & 8 & 9 \\
$\mathrm{CV}$ & 9,69 & 17,57 & 14,15 & 16,86 & 12,49 & 15,41 \\
\hline
\end{tabular}

*. Médias seguidas de letras iguais não diferem entre si e as seguidas de letras diferentes diferem significativamente ao nivel de $\mathrm{P}=0,05$. 
Tabela XXVI. Duração média (X),em dias, do ciclo evolutivo de Anacassis dubia (1), A. fuscata (2), A. fuscata (forma) (3), A. languida (4) e A. phaeopoda (5). Desvio Padrão (s), Amplitude $(<$ e $\rangle$ ) e Coeficiente de Variação (CV). Temperatura $25 \pm 2^{\circ} \mathrm{C}$, fotofase $12 \mathrm{~h}$, U.R. $85 \pm 5 \%$.

\begin{tabular}{cccccc}
\hline & 1 & 2 & 3 & 4 & 5 \\
\hline$N$ & 14 & 10 & 13 & 5 & 15 \\
$X$ & $48,86 b$ & $33,30 a$ & $32,23 a$ & $46,80 b$ & $35,93 a$ \\
$S$ & 5,3039 & 4,2177 & 2,0064 & 2,8635 & 4,2167 \\
$<$ & 38 & 27 & 28 & 43 & 31 \\
$>$ & 54 & 40 & 36 & 50 & 43 \\
CV & 10,86 & 12,67 & 6,23 & 6,12 & 11,73 \\
\hline
\end{tabular}

*. Médias seguidas de letras iguais não diferem entre si e as seguidas de letras diferentes diferem significativamente ao nível de $\mathrm{P}=0,05$.

Tabela XXVII. Tabela de Esperança de Vida de Anacassis dubia, em laboratório. Temperatura $25 \pm 2^{\circ} \mathrm{C}$, fotofase $12 \mathrm{~h}$, U.R. $85 \pm 5 \%$.

\begin{tabular}{llllrrrc}
\hline \multicolumn{1}{c}{$\mathrm{x}$} & $\mathrm{Ix}$ & $\mathrm{dx}$ & $\mathrm{Lx}$ & $\mathrm{Tx}$ & $\mathrm{ex}$ & 100qx \\
\hline 1 & Ovo & 20 & 1 & 19,00 & 107,00 & 5,35 & 0,05 \\
2 & Larva I & 19 & 1 & 18,50 & 87,50 & 4,61 & 0,05 \\
3 & Larva 2 & 18 & 3 & 16,50 & 69,00 & 3,83 & 0,17 \\
4 & Larva III & 15 & 1 & 14,50 & 52,50 & 3,50 & 0,06 \\
5 & Larva IV & 14 & 1 & 13,50 & 38,00 & 2,71 & 0,07 \\
6 & Larva V & 13 & 1 & 12,50 & 24,50 & 1,88 & 0,07 \\
7 & Pupa & 12 & 0 & 12,00 & 12,00 & 1,00 & 0,00 \\
8 & Adulto & 12 & - & - & - & - & - \\
\hline
\end{tabular}

Tabela XXVIII. Tabela de Esperança de Vida de Anacassis fuscata, em laboratório. Temperatura $25 \pm 2^{\circ} \mathrm{C}$, fotofase 12 h, U.R. $85 \pm 5 \%$.

\begin{tabular}{llcccccc}
\hline \multicolumn{1}{c}{$\mathrm{x}$} & $\mathrm{Ix}$ & $\mathrm{dx}$ & $\mathrm{Lx}$ & $\mathrm{Tx}$ & $\mathrm{ex}$ & 100qx \\
\hline 1 & Ovo & 30 & 3 & 28,50 & 134,50 & 4,48 & 0,10 \\
2 & Larva I & 27 & 6 & 24,00 & 106,00 & 3,93 & 0,22 \\
3 & Larva 2 & 21 & 3 & 19,50 & 82,00 & 3,90 & 0,14 \\
4 & Larva III & 18 & 1 & 17,50 & 62,50 & 3,47 & 0,05 \\
5 & Larva IV & 17 & 1 & 16,50 & 45,00 & 2,65 & 0,06 \\
6 & Larva V & 16 & 2 & 15,00 & 28,50 & 1,78 & 0,13 \\
7 & Pupa & 14 & 1 & 13,50 & 13,50 & 0,96 & 0,07 \\
8 & Adulto & 13 & - & - & - & - & - \\
\hline
\end{tabular}


Tabela XXIX. Tabela de Esperança de Vida de Anacassis fuscata (forma), em laboratório. Temperatura $25 \pm 2^{\circ} \mathrm{C}$, fotofase 12 h, U.R. $85 \pm 5 \%$ ).

\begin{tabular}{llcccccc}
\hline \multicolumn{1}{c}{$\mathrm{x}$} & $\mathrm{Ix}$ & $\mathrm{dx}$ & $\mathrm{Lx}$ & $\mathrm{Tx}$ & $\mathrm{ex}$ & 100qx \\
\hline 1 & Ovo & 48 & 10 & 43,00 & 220,50 & 4,60 & 0,21 \\
2 & Larva I & 38 & 4 & 36,00 & 177,50 & 4,67 & 0,11 \\
3 & Larva 2 & 34 & 3 & 32,50 & 141,50 & 4,16 & 0,09 \\
4 & Larva III & 31 & 3 & 29,50 & 109,00 & 3,52 & 0,10 \\
5 & Larva IV & 28 & 1 & 27,50 & 79,50 & 2,83 & 0,04 \\
6 & Larva V & 27 & 1 & 26,50 & 52,00 & 1,93 & 0,04 \\
7 & Pupa & 26 & 1 & 25,50 & 25,50 & 0,98 & 0,04 \\
8 & Adulto & 25 & - & - & - & - & - \\
\hline
\end{tabular}

Tabela XXX. Tabela de Esperança de Vida de Anacassis languida, em laboratório. Temperatura $25 \pm 2^{\circ} \mathrm{C}$, fotofase 12 h, U.R. $85 \pm 5 \%$.

\begin{tabular}{llcccccc}
\hline \multicolumn{1}{c}{$\mathrm{x}$} & $\mathrm{Ix}$ & $\mathrm{dx}$ & $\mathrm{Lx}$ & $\mathrm{Tx}$ & $\mathrm{ex}$ & 100qx \\
\hline 1 & Ovo & 20 & 2 & 19,00 & 105,00 & 5,28 & 0,11 \\
2 & Larva I & 18 & 2 & 17,00 & 86,50 & 4,80 & 0,11 \\
3 & Larva 2 & 16 & 1 & 15,50 & 69,50 & 4,34 & 0,06 \\
4 & Larva III & 15 & 1 & 14,50 & 54,00 & 3,60 & 0,07 \\
5 & Larva IV & 14 & 1 & 13,50 & 39,50 & 2,82 & 0,07 \\
6 & Larva V & 13 & 0 & 13,00 & 26,00 & 2,00 & 0,00 \\
7 & Pupa & 13 & 0 & 13,00 & 13,00 & 1,00 & 0,00 \\
8 & Adulto & 13 & - & 0 & 0 & - & - \\
\hline
\end{tabular}

Tabela XXXI. Tabela de Esperança de Vida de Anacassis phaeopoda, em laboratório. Temperatura $25 \pm 2^{\circ} \mathrm{C}$, fotofase $12 \mathrm{~h}$, U.R. $85 \pm 5 \%$.

\begin{tabular}{llcccccc}
\hline \multicolumn{1}{c}{$\mathrm{x}$} & $\mathrm{Ix}$ & $\mathrm{dx}$ & $\mathrm{Lx}$ & $\mathrm{Tx}$ & $\mathrm{ex}$ & $100 \mathrm{qx}$ \\
\hline 1 & Ovo & 56 & 26 & 43,00 & 135,50 & 2,42 & 0,46 \\
2 & Larva I & 30 & 8 & 216,00 & 92,50 & 3,08 & 0,27 \\
3 & Larva 2 & 22 & 4 & 20,00 & 66,50 & 3,02 & 0,19 \\
4 & Larva III & 18 & 6 & 15,00 & 46,50 & 2,58 & 0,33 \\
5 & Larva IV & 12 & 1 & 11,50 & 31,50 & 2,63 & 0,08 \\
6 & Larva V & 11 & 1 & 10,50 & 20,00 & 1,19 & 0,09 \\
7 & Pupa & 10 & 1 & 9,50 & 9,50 & 0,95 & 0,10 \\
8 & Adulto & 9 & - & - & - & - & - \\
\hline
\end{tabular}




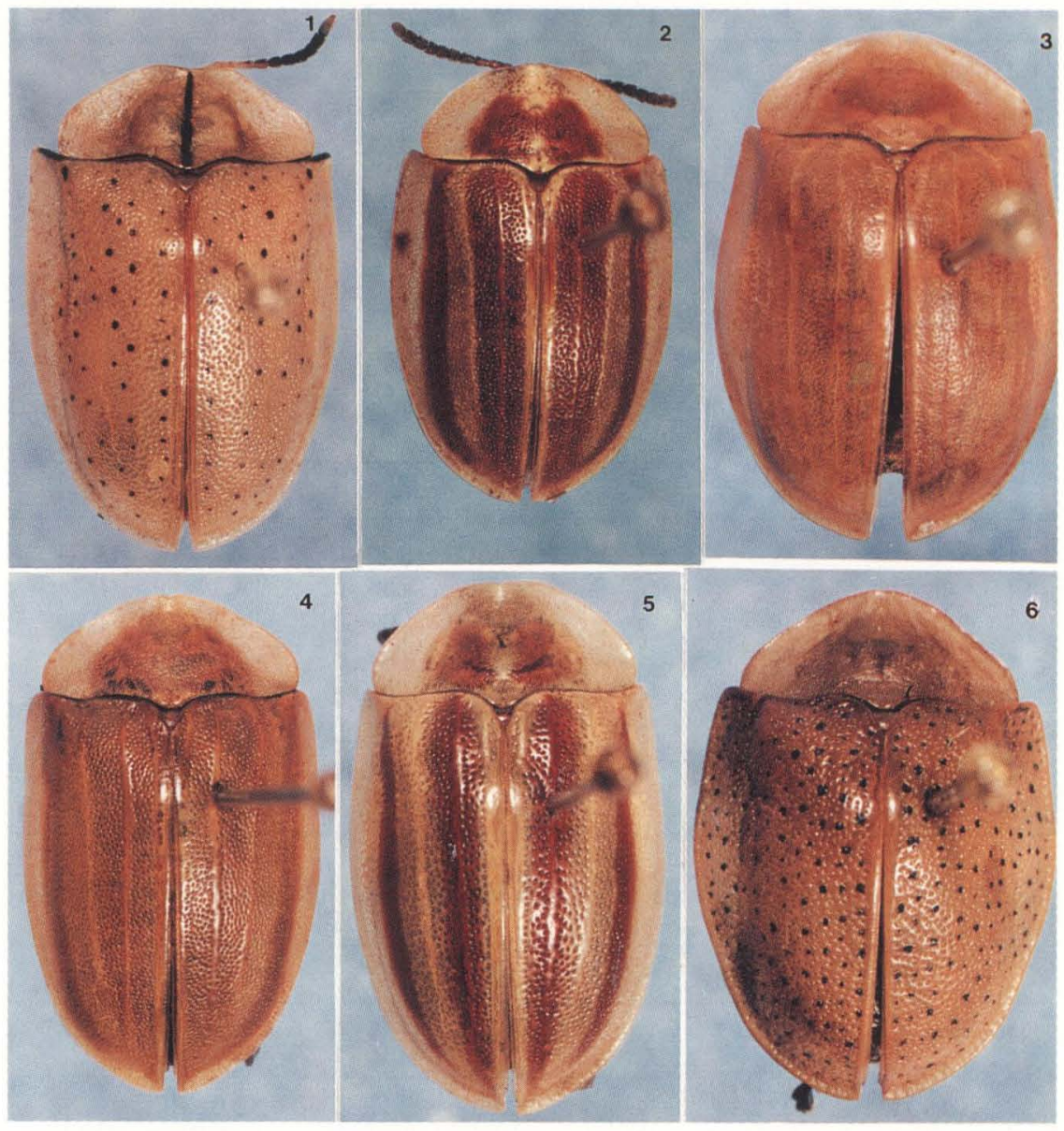

Figs 1-6. Vista dorsal de: (1) Anacassis dubia; (2) A. fuscata; (3) A. languida; (4) A. fuscata (forma); (5) A. phaeopoda; (6) A. punctulata. 

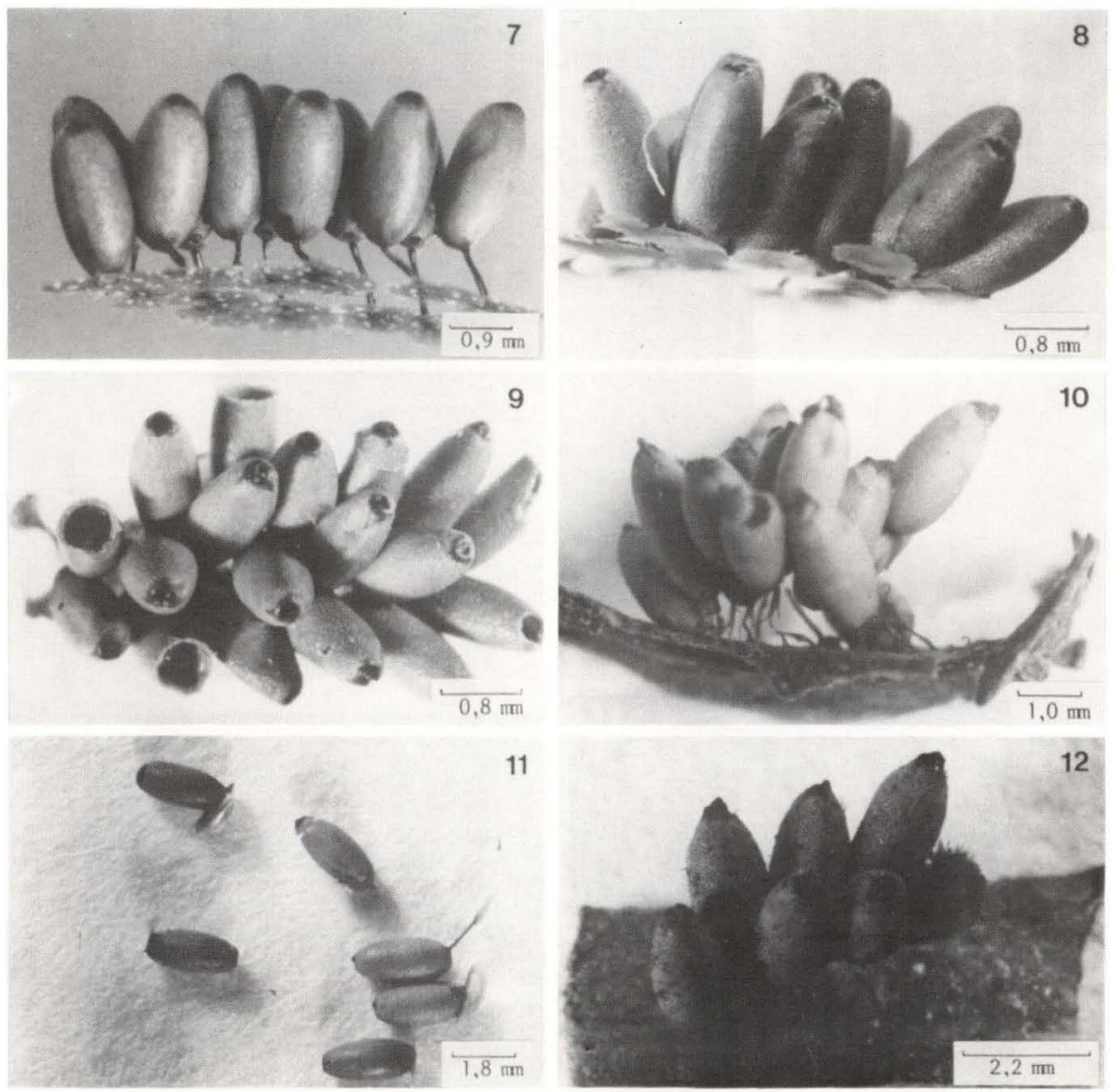

Figs 7-12. Ovos de: (7) Anacassis dubia; (8) A. fuscata; (9) A. fuscata (forma); (10) A. languida; (11) A. phaeopoda; (12) A. punctulata. 

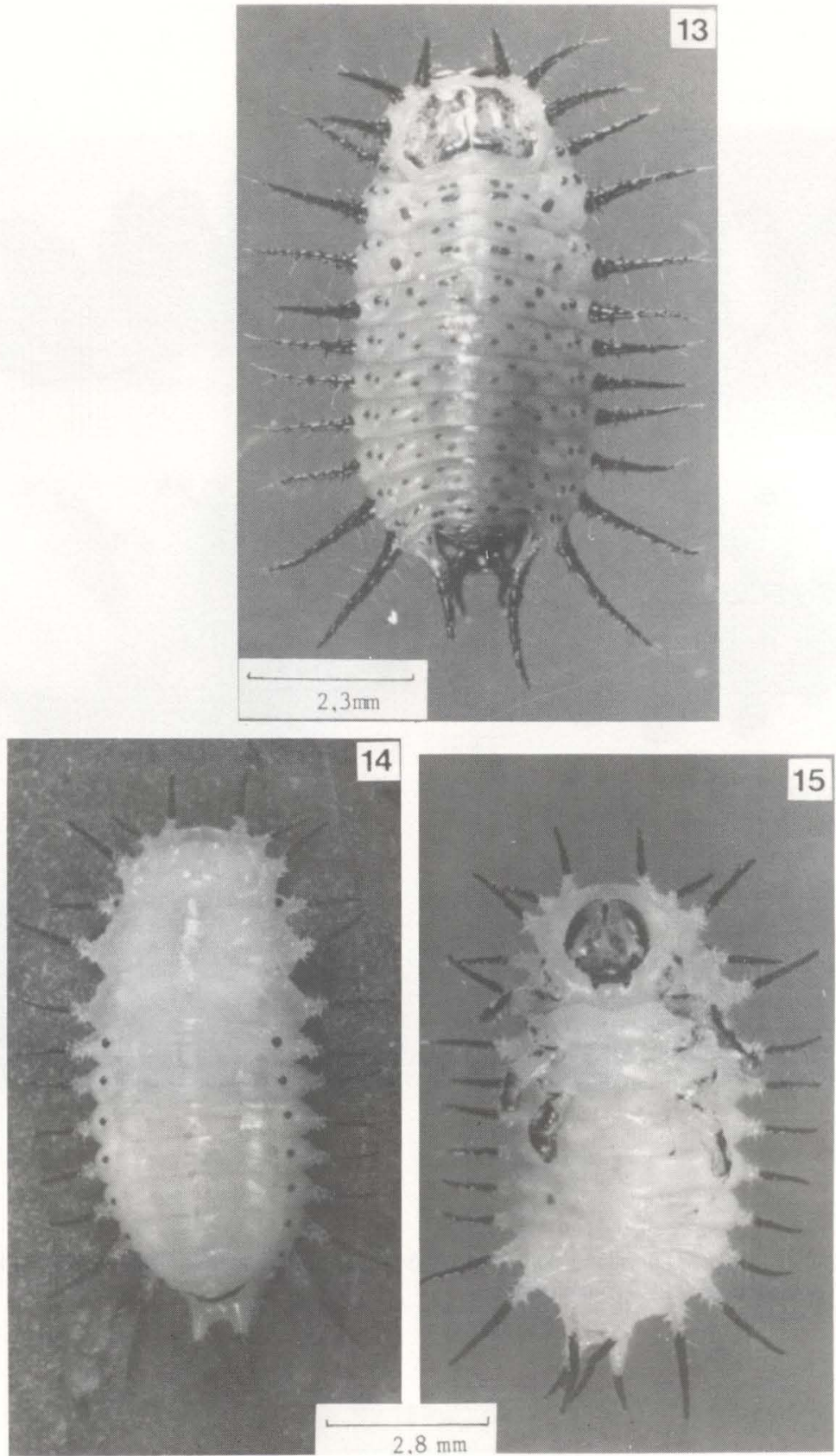

Figs 13-15. Anacassis dubia, larva. (13) Quarto ínstar, vista dorsal; (14) quinto instar, vista dorsal e (15) ventral.

Revta bras. Zool. 13 (1): 215 - 289, 1996 

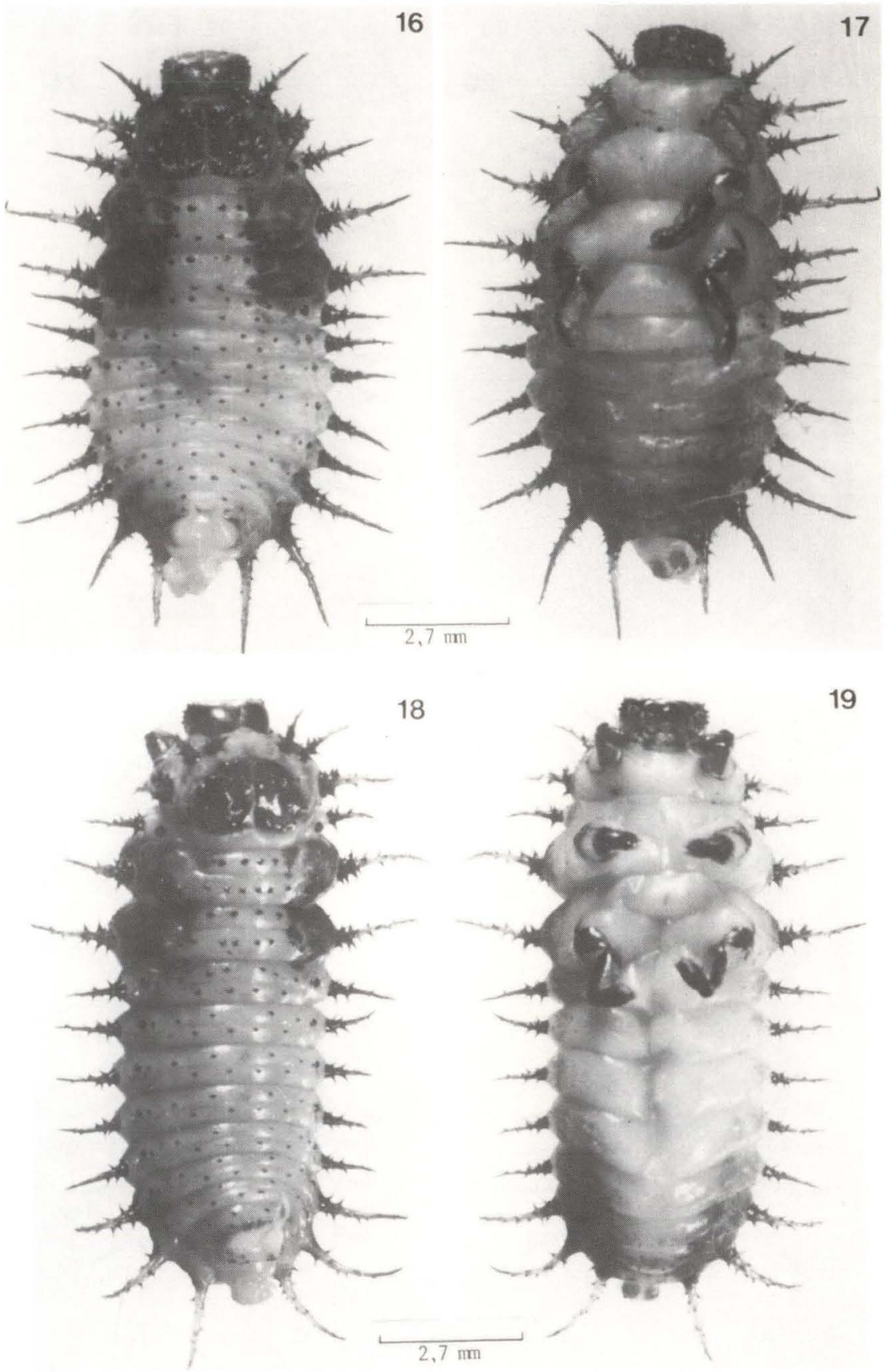

Figs 16-19. Larva de quinto instar de Anacassis fuscata: (16) vista dorsal e (17) ventral; $A$. fuscata (forma): (18) vista dorsal e (19) ventral. 


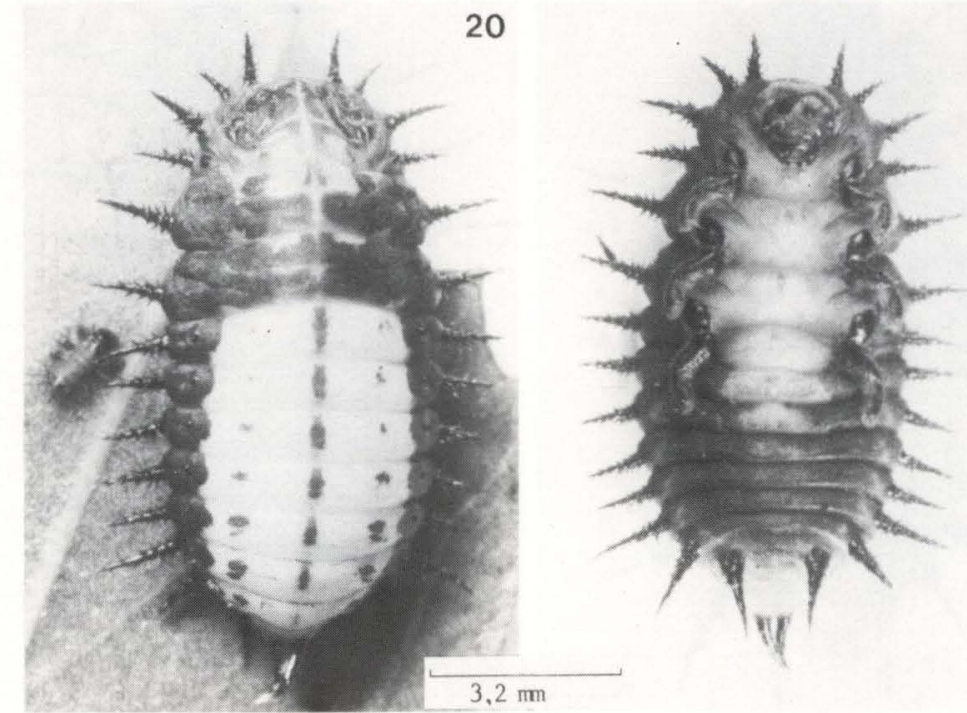

21

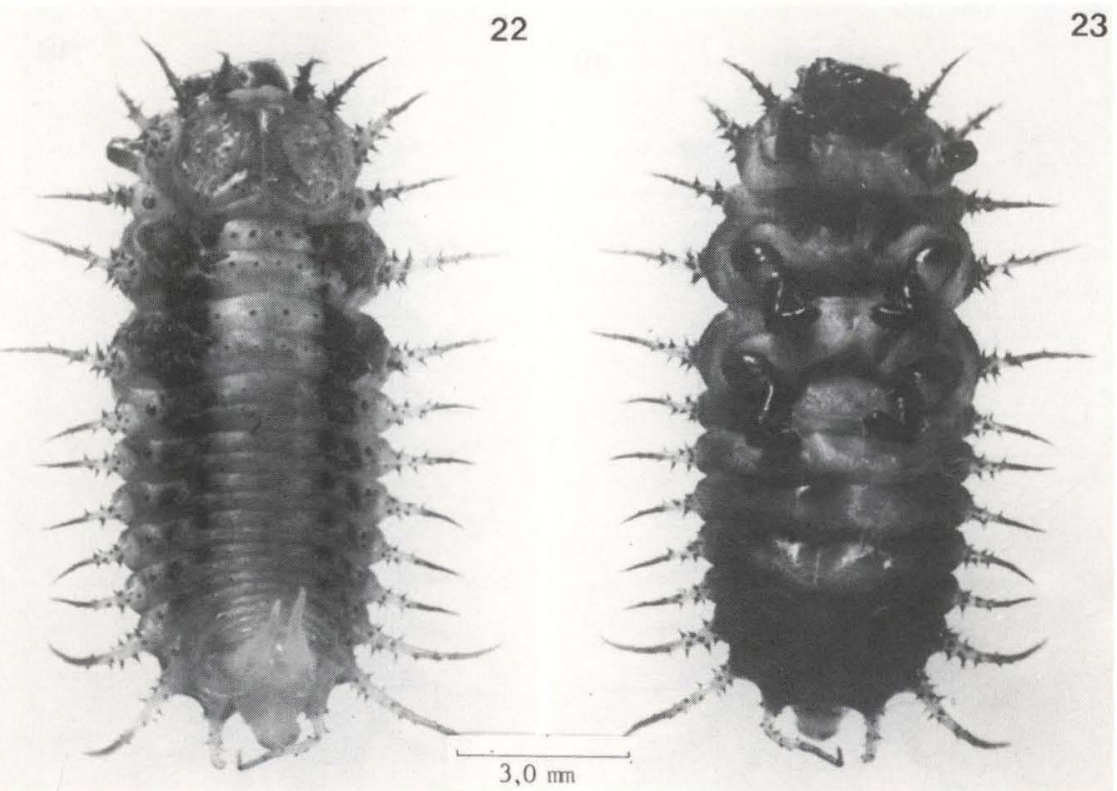

Figs 20-23. Larva de quinto instar. Anacassis languida: (20) vista dorsal e (21) ventral; $A$. phaeopoda: (22) vista dorsal e (23) ventral. 

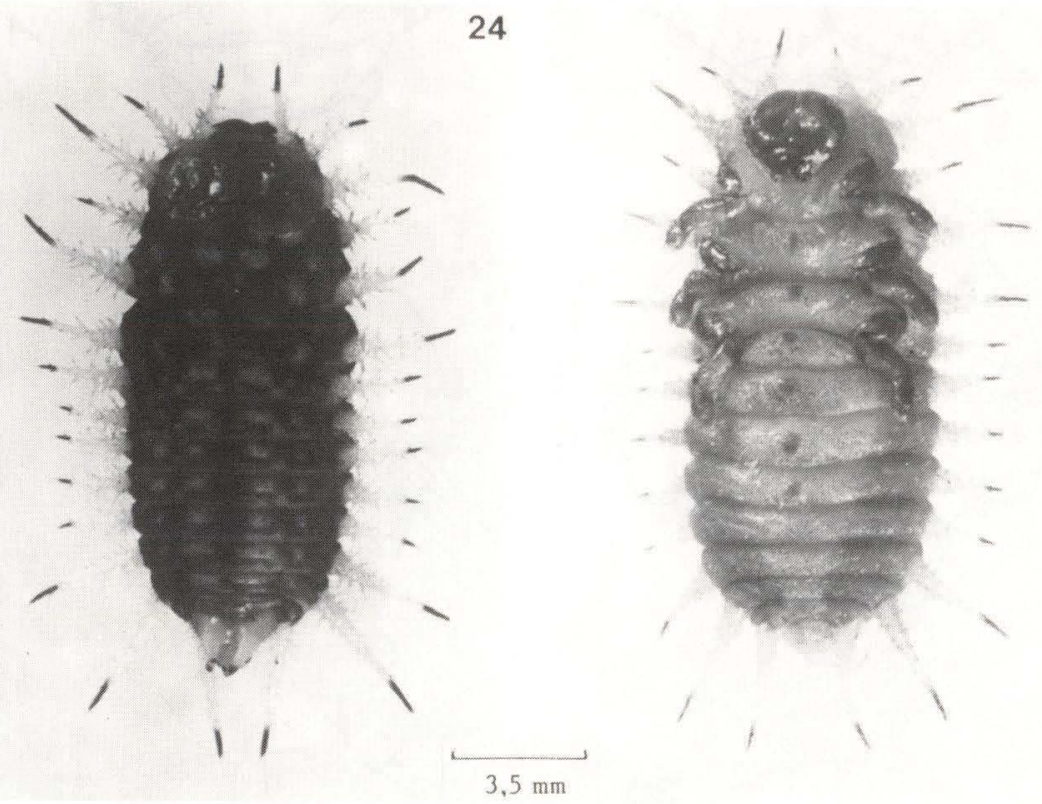

Figs 24-25. Larva de quinto ínstar. Anacassis punctulata: (24) vista dorsal e (25) ventral. 

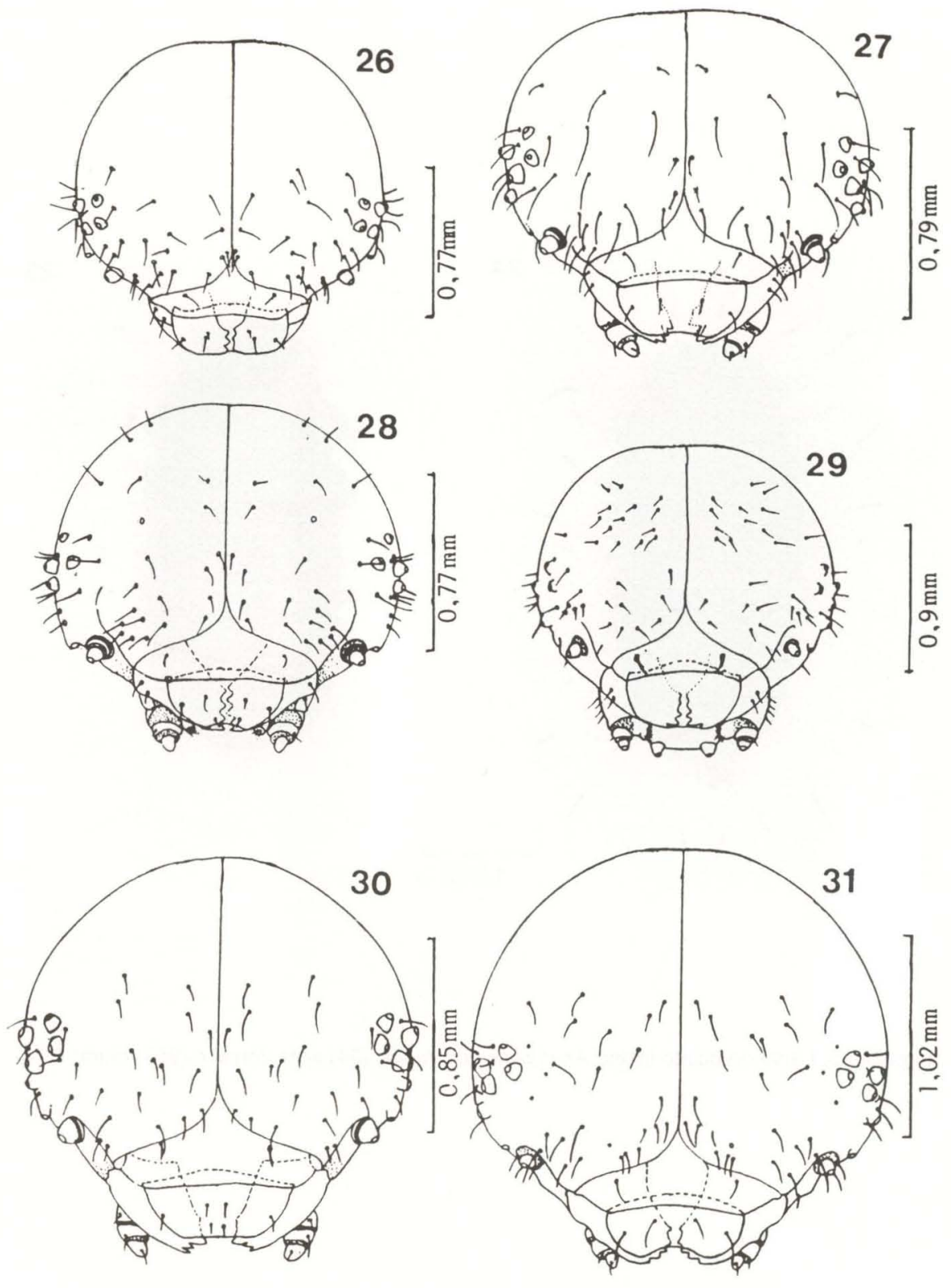

Figs 26-31. Cabeça da larva de quinto ínstar em vista frontal. (26) Anacassis dubia; (27) A. fuscata; (28) A. fuscata (forma); (29) A. languida; (30) A. phaeopoda; (31) A. punctulata. 

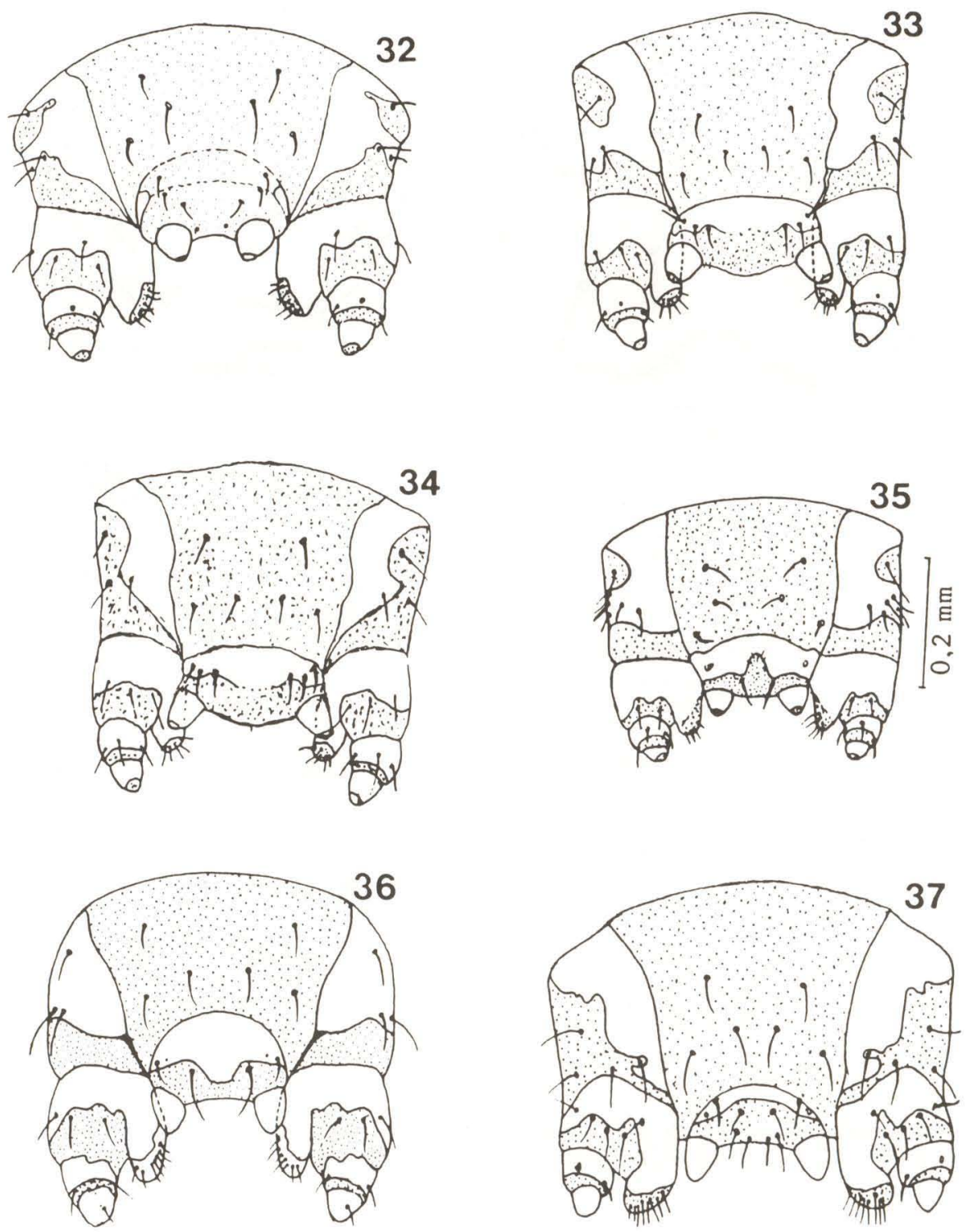

Figs 32-37. Maxilas e lábio da larva de quinto instar. (32) Anacassis dubia; (33) A. fuscata; (34) A. fuscata (forma); (35) A. languida; (36) A. phaeopoda; (37) A. punctulata. 

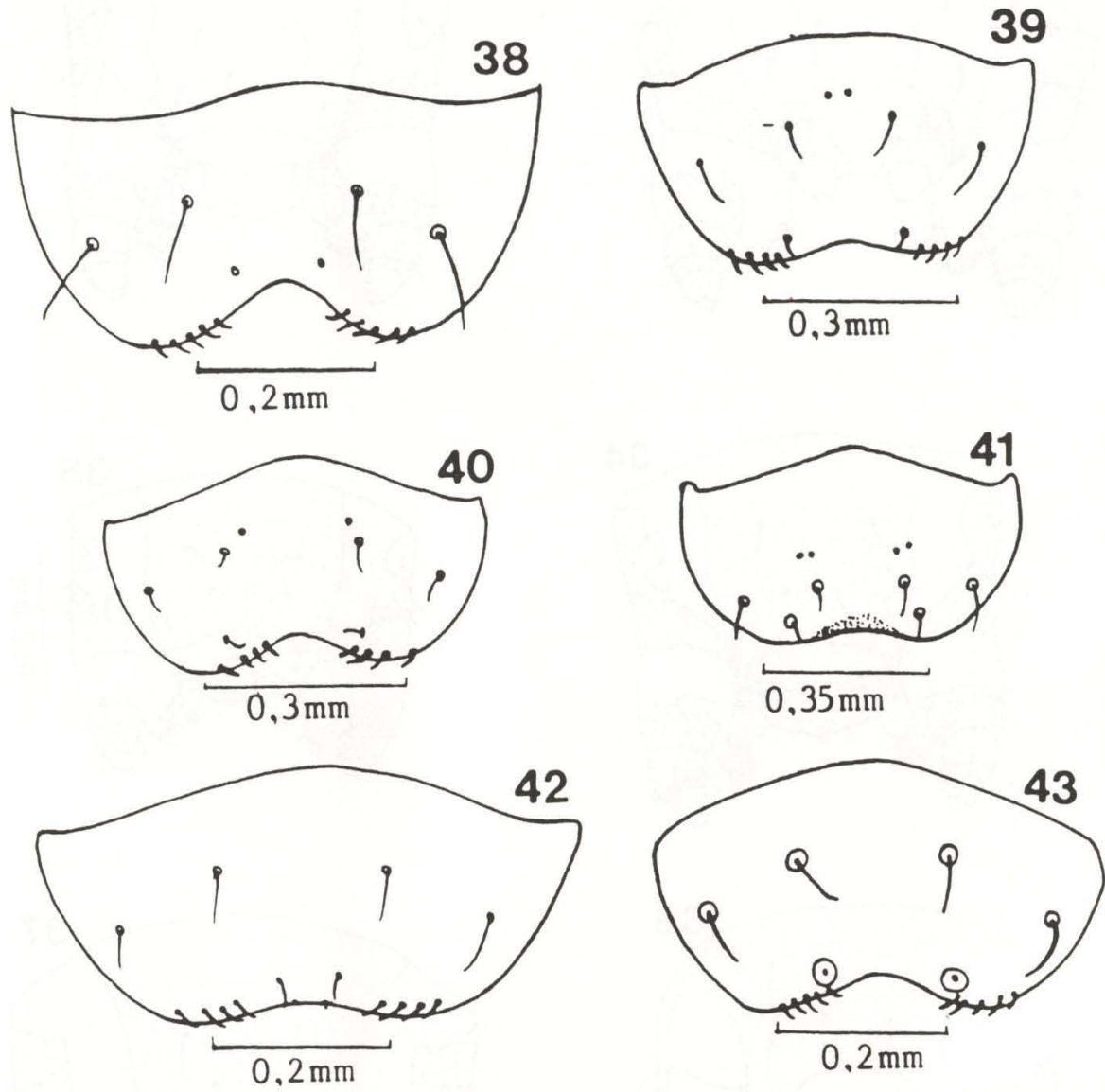

Figs 38-43. Labro da larva de quinto instar. (38) Anacassis dubia (39) A. fuscata; (40) A. fuscata (forma); (41) A. languida; (42) A. phaeopoda; (43) A. punctulata. 

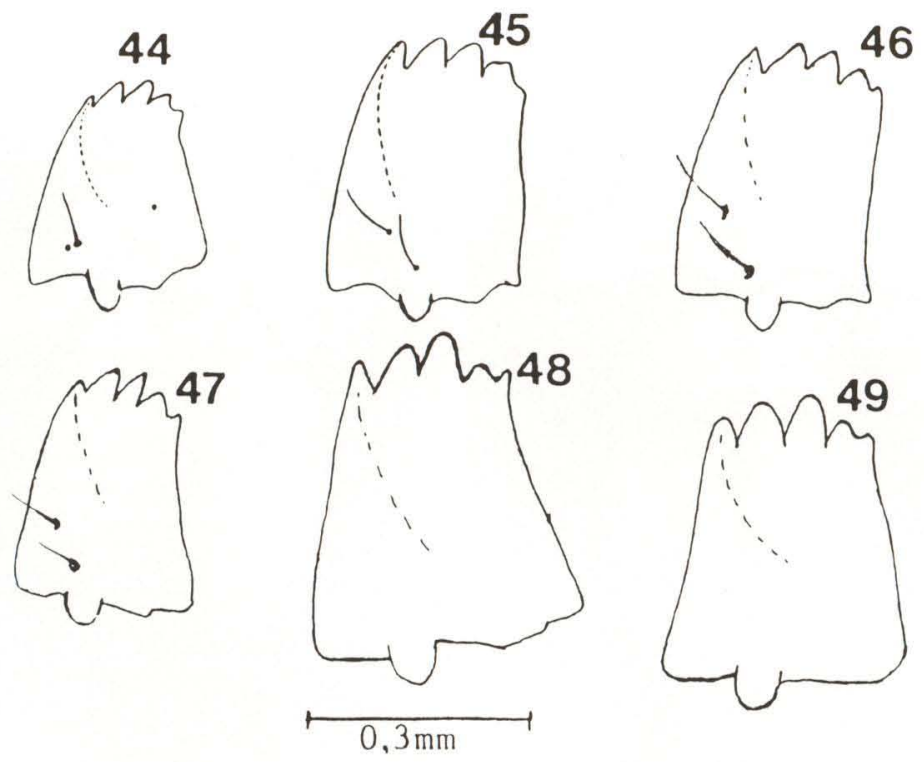

Figs 44-49. Mandíbula da larva de quinto ínstar. (44) Anacassis dubia; (45) A. fuscata; (46) A. fuscata (forma); (47) A. languida; (48) A. phaeopoda; (49) A. punctulata.
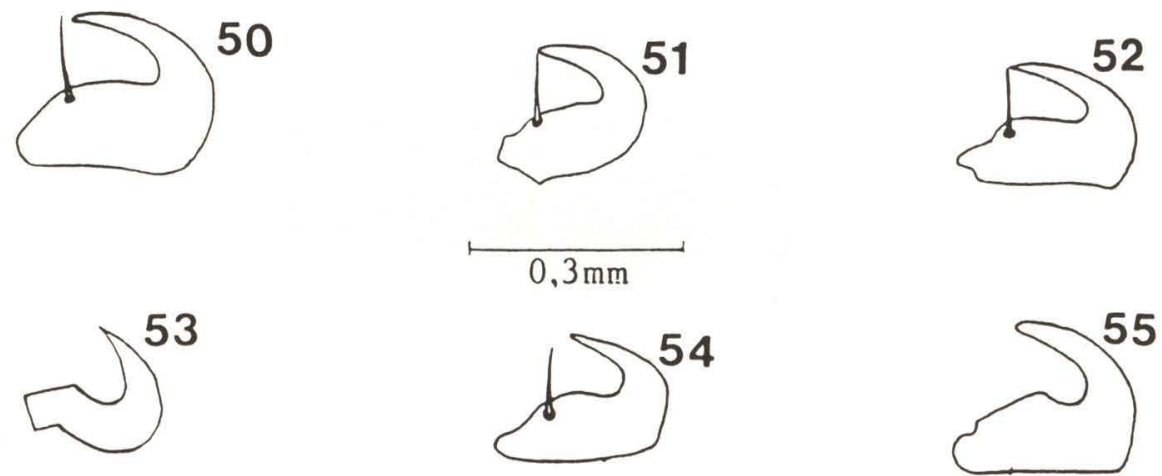

Figs 50-55. Tarsúngulo anterior da larva de quinto instar. (50) Anacassis dubia; (51) A. fuscata; (52) A. fuscata (forma); (53) A.languida; (54) A. phaeopoda; (55) A. punctulata. 

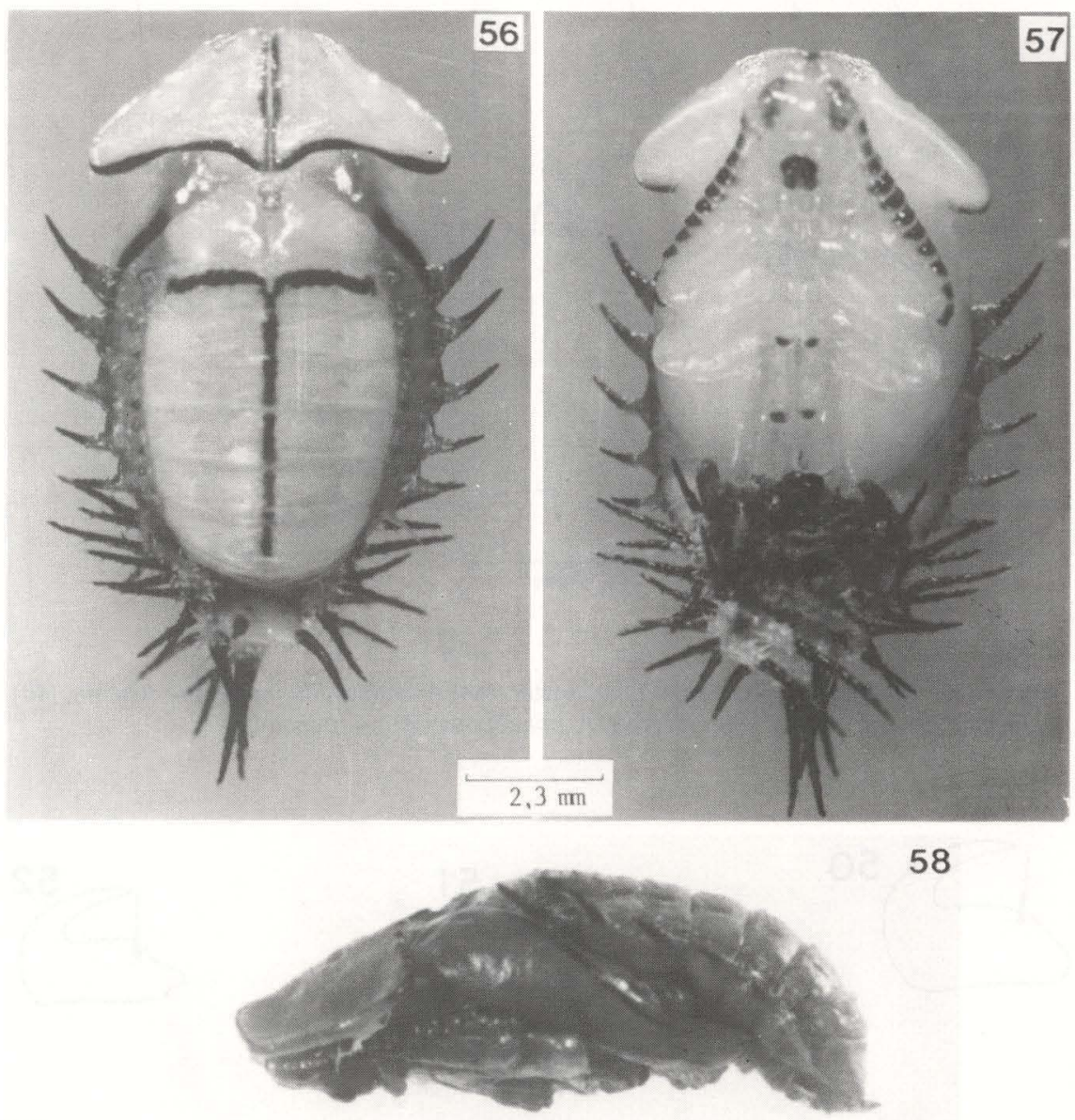

58

Figs 56-58. Anacassis dubia, pupa. (56) Vista dorsal, (57) ventral e (58) lateral. 

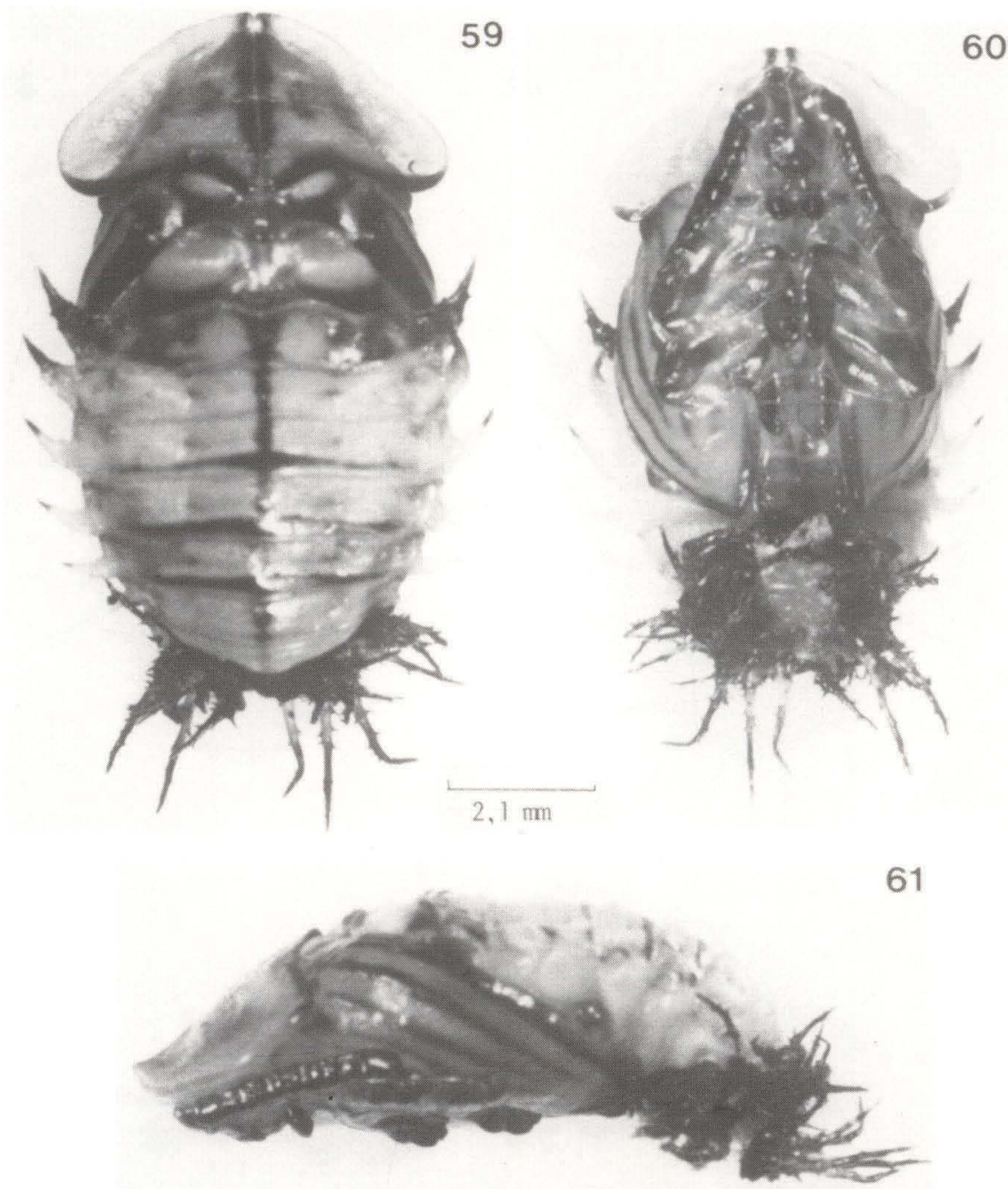

Figs 59-61. Anacassis fuscata, pupa. (59) Vista dorsal, (60) ventral e (61) lateral. 


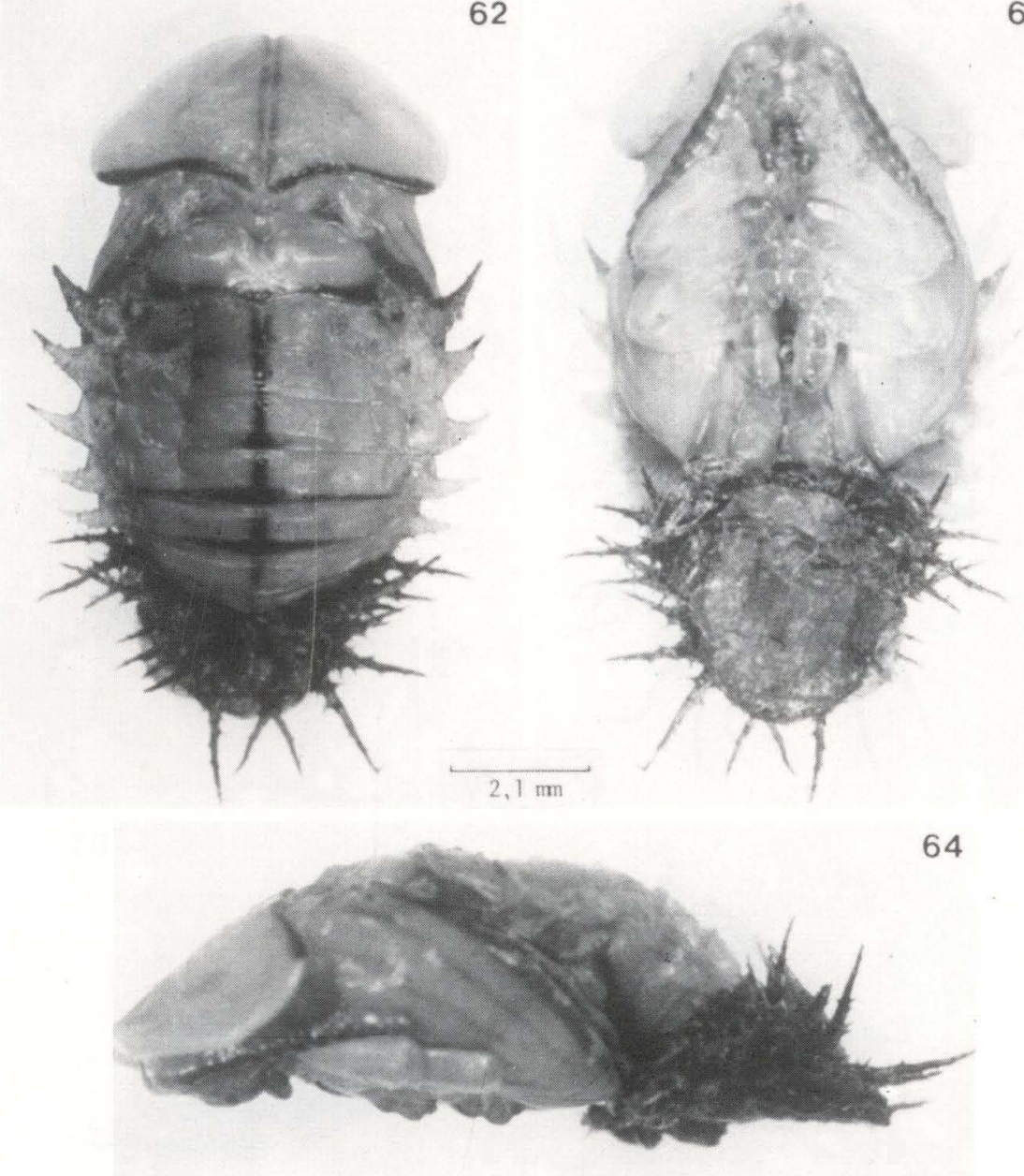

Figs 62-64. Anacassis fuscata (forma), pupa. (62) Vista dorsal, (63) ventral e (64) lateral. 


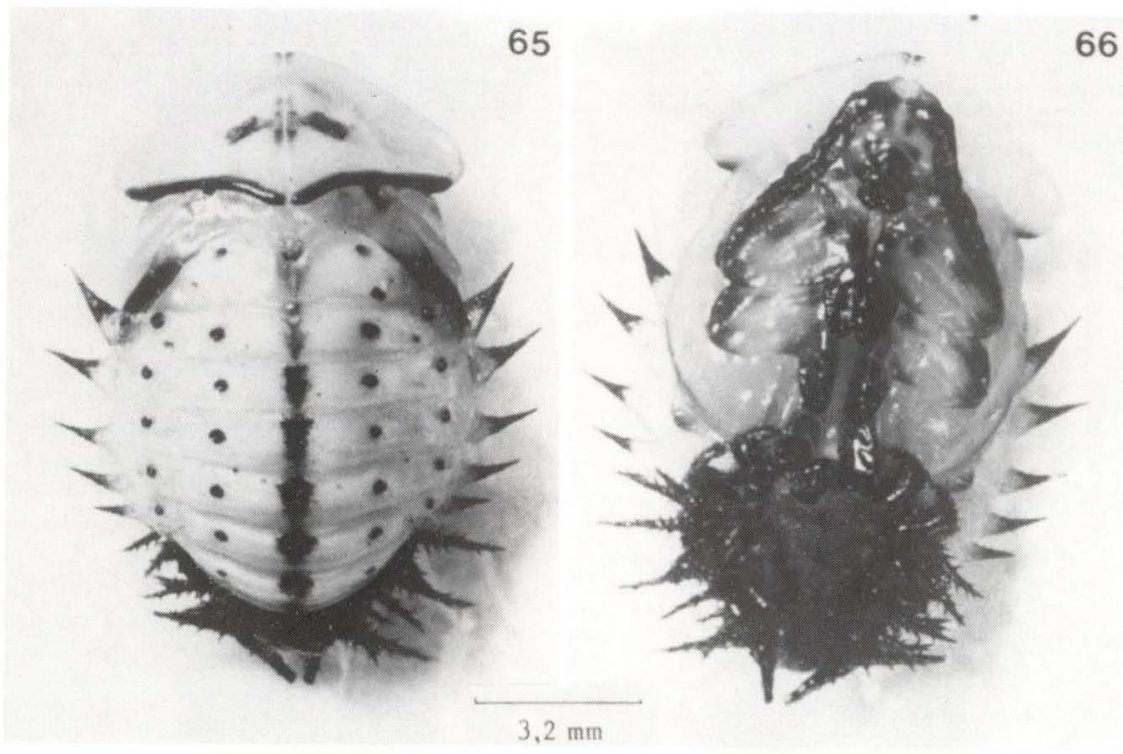

67

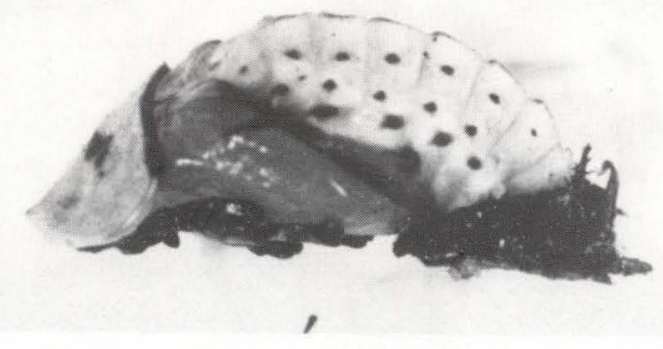

Figs 65-67. Anacassis languida, pupa. (65) Vista dorsal, (66) ventral e (67) lateral. 


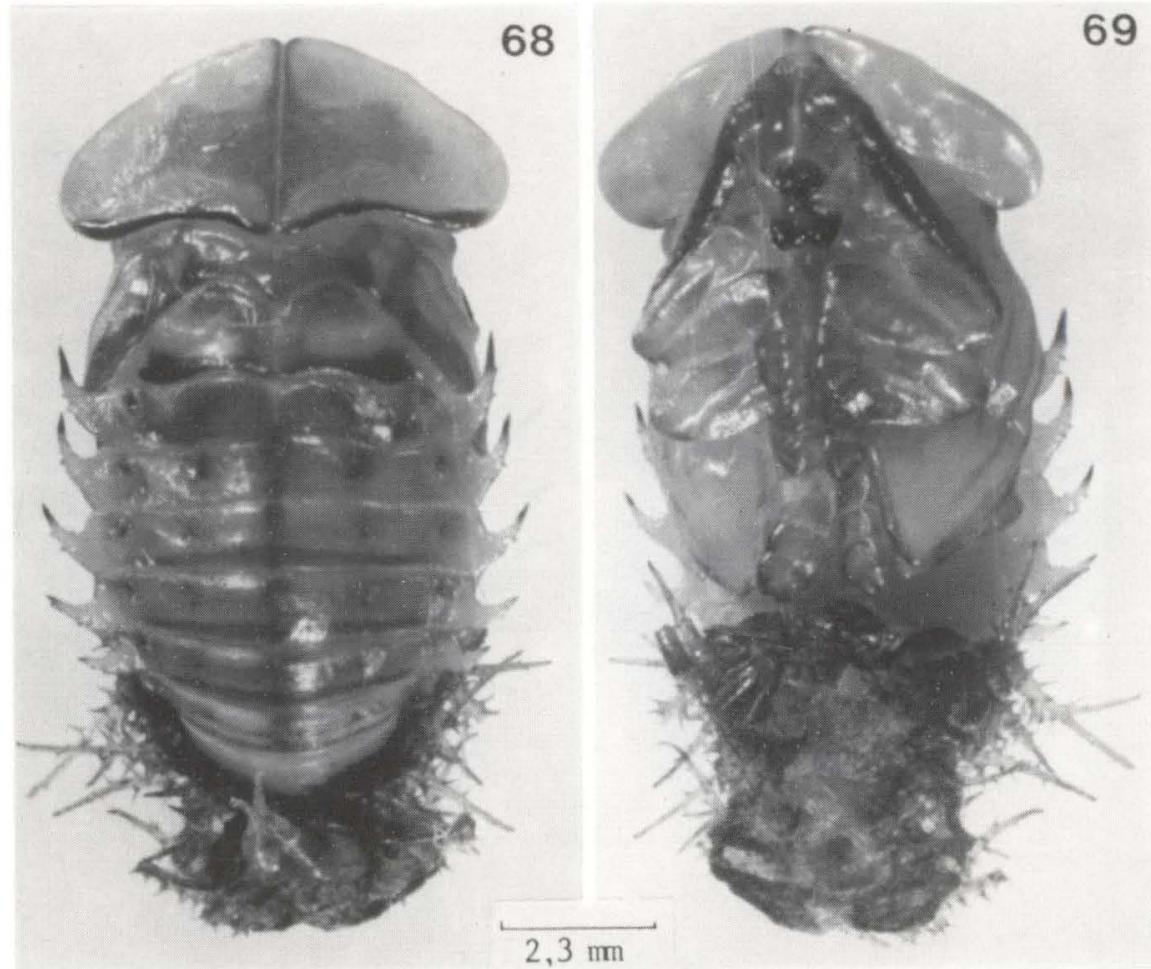

70

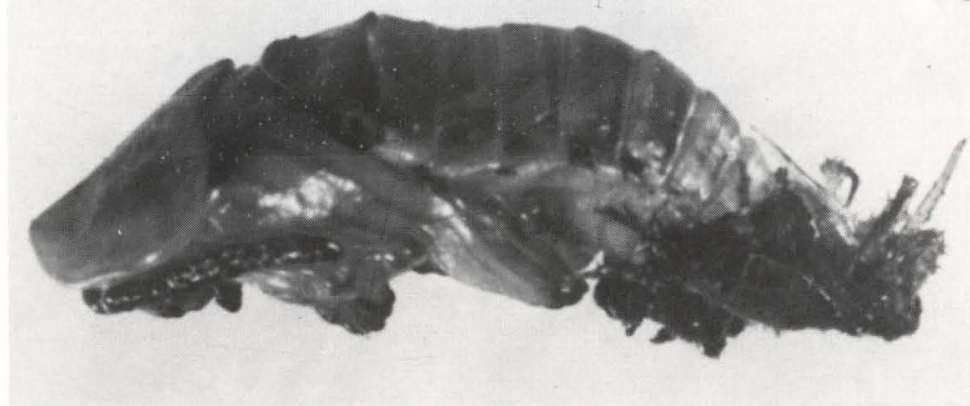

Figs 68-70. Anacassis phaeopoda, pupa. (68) Vista dorsal, (69) ventral e (70) lateral. 


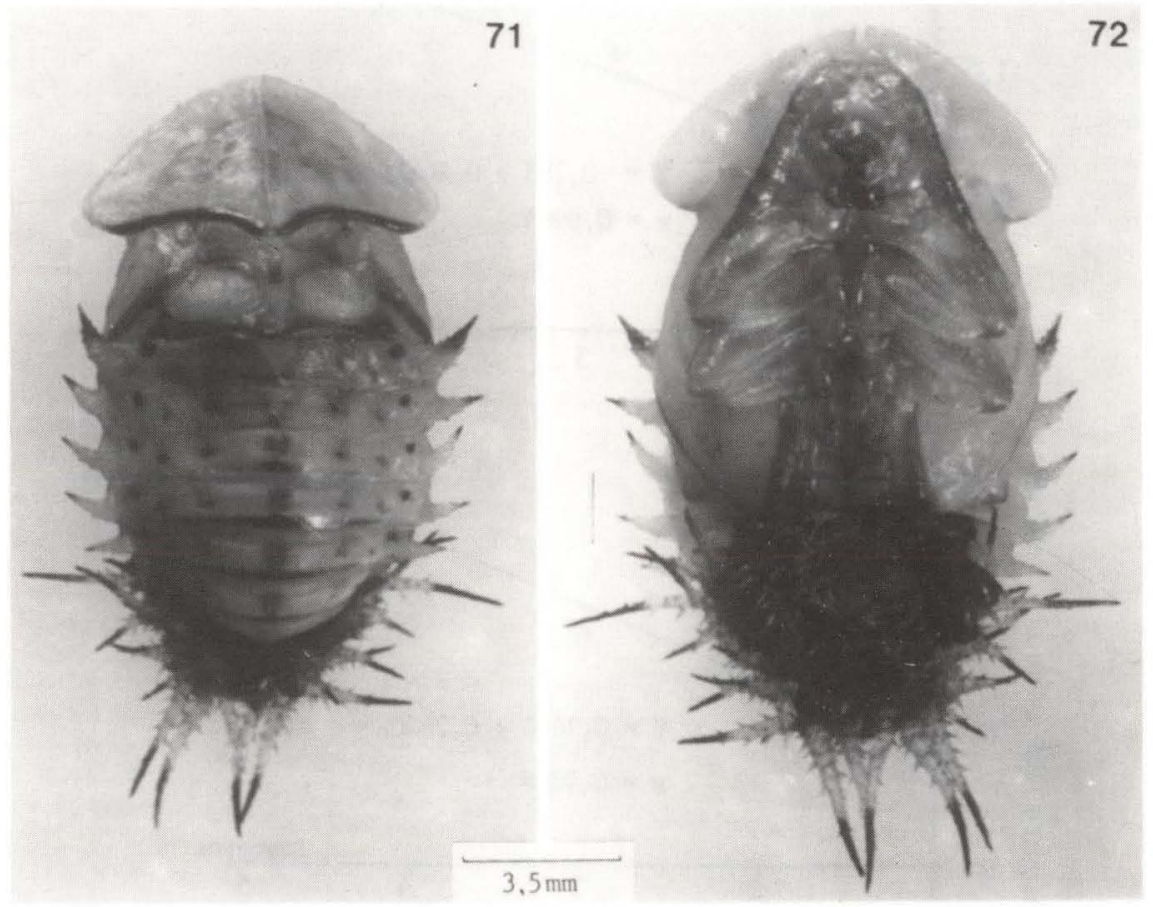

73

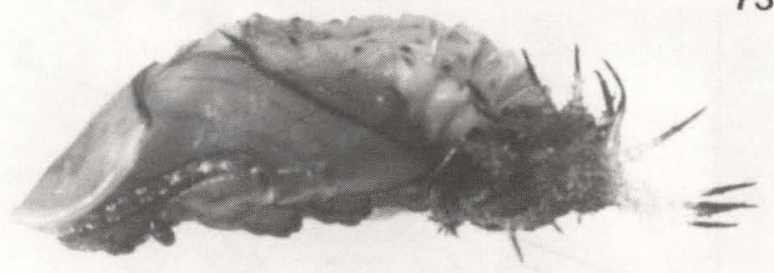

Figs 71-73. Anacassis punctulata, pupa. (71) Vista dorsal, (72) ventral e (73) lateral. 

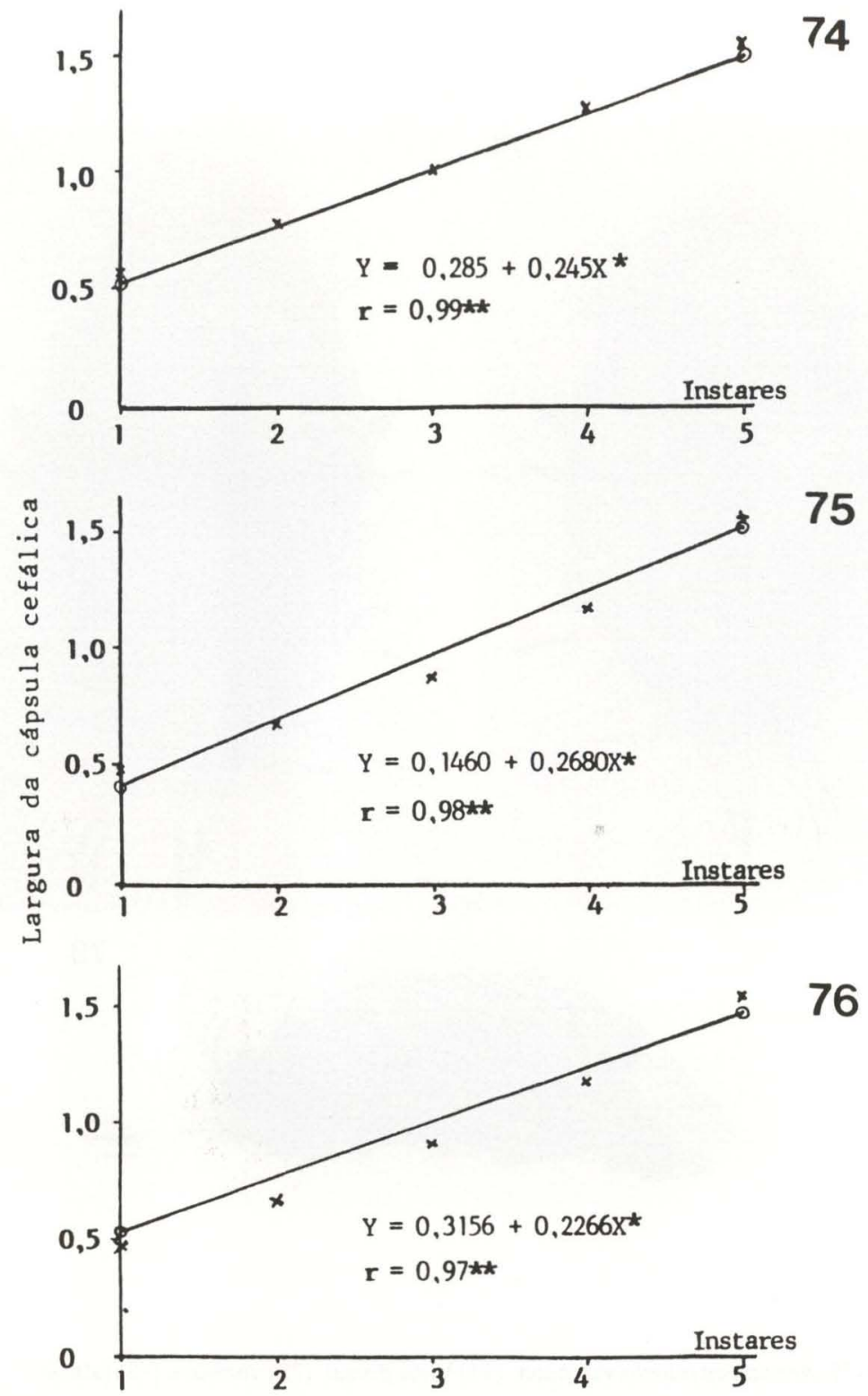

Figs 74-76. Reta de regressão linear do crescimento geométrico da largura da cápsula cefálica em função dos instares larvais. (74) Anacassis dubia; (75) A. fuscata; (76) A. fuscata (forma). $\left(^{*}\right)$ Equação da reta, $\left(^{* *}\right)$ Coeficiente de correlação linear. 

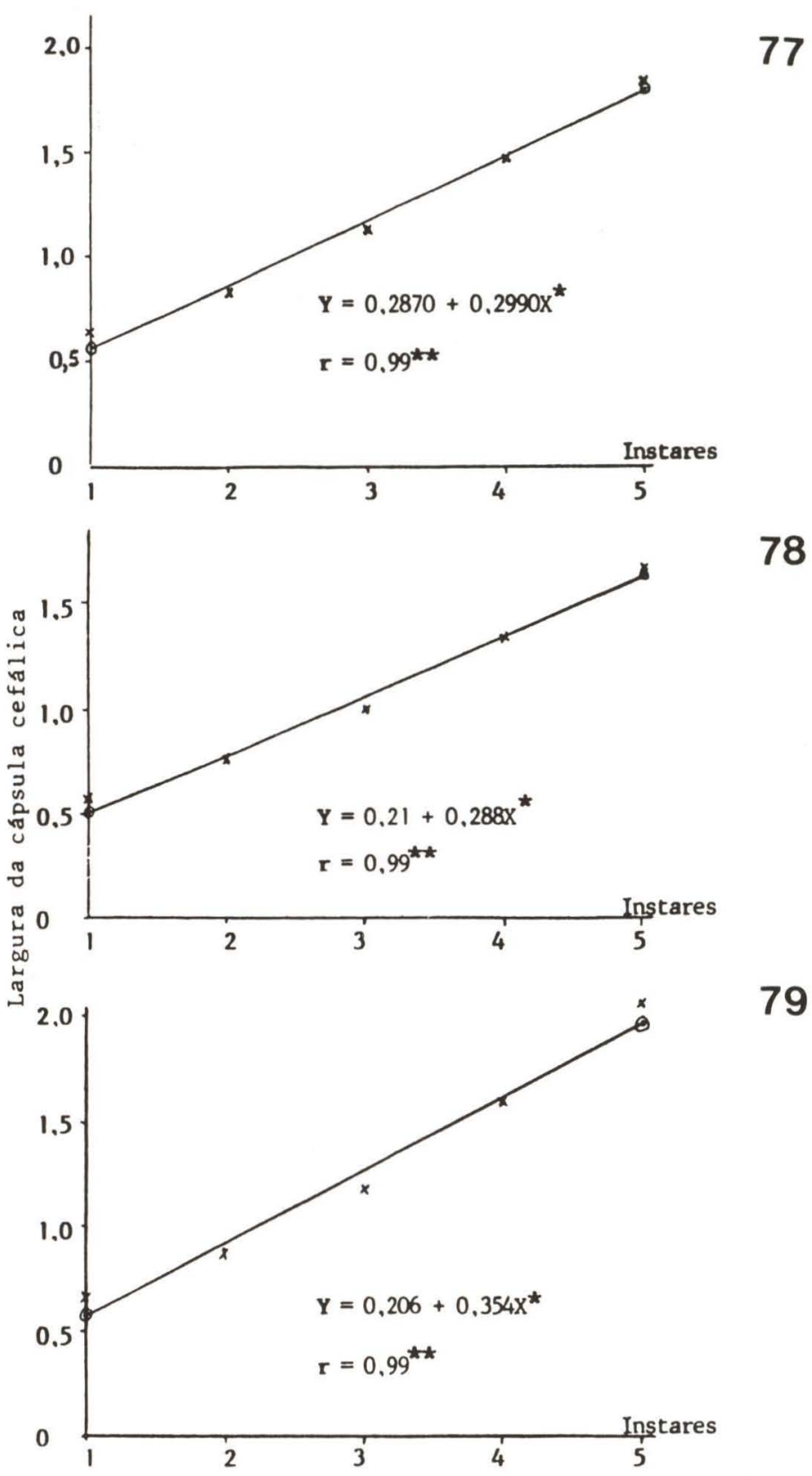

Figs 77-79. Reta de regressão linear do crescimento geométrico da largura da cápsula cefálica em função dos ínstares larvais. (77) Anacassis languida; (78) A. phaeopoda; (79) A. punctulata. $\left.{ }^{*}\right)$ Equação da reta, $\left(^{* \star}\right)$ Coeficiente de correlação linear. 

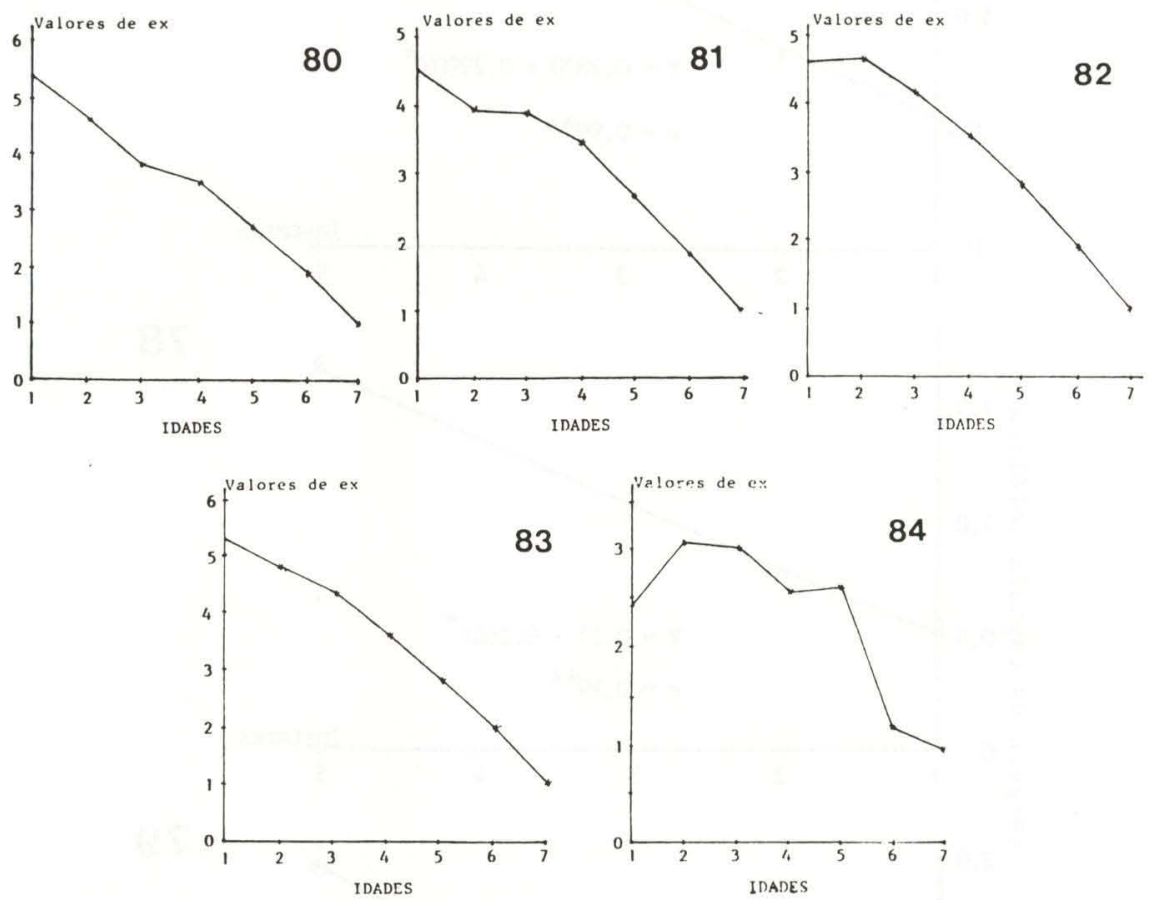

Figs 80-84. Curvas de Esperança de Vida. (80) Anacassis dubia; (81) A. fuscata; (82) A. fuscata (forma); (83) A. languida; (84) A. phaeopoda. Idades: (1) Ovo, (2-6) instares larvais, (7) pupa. 

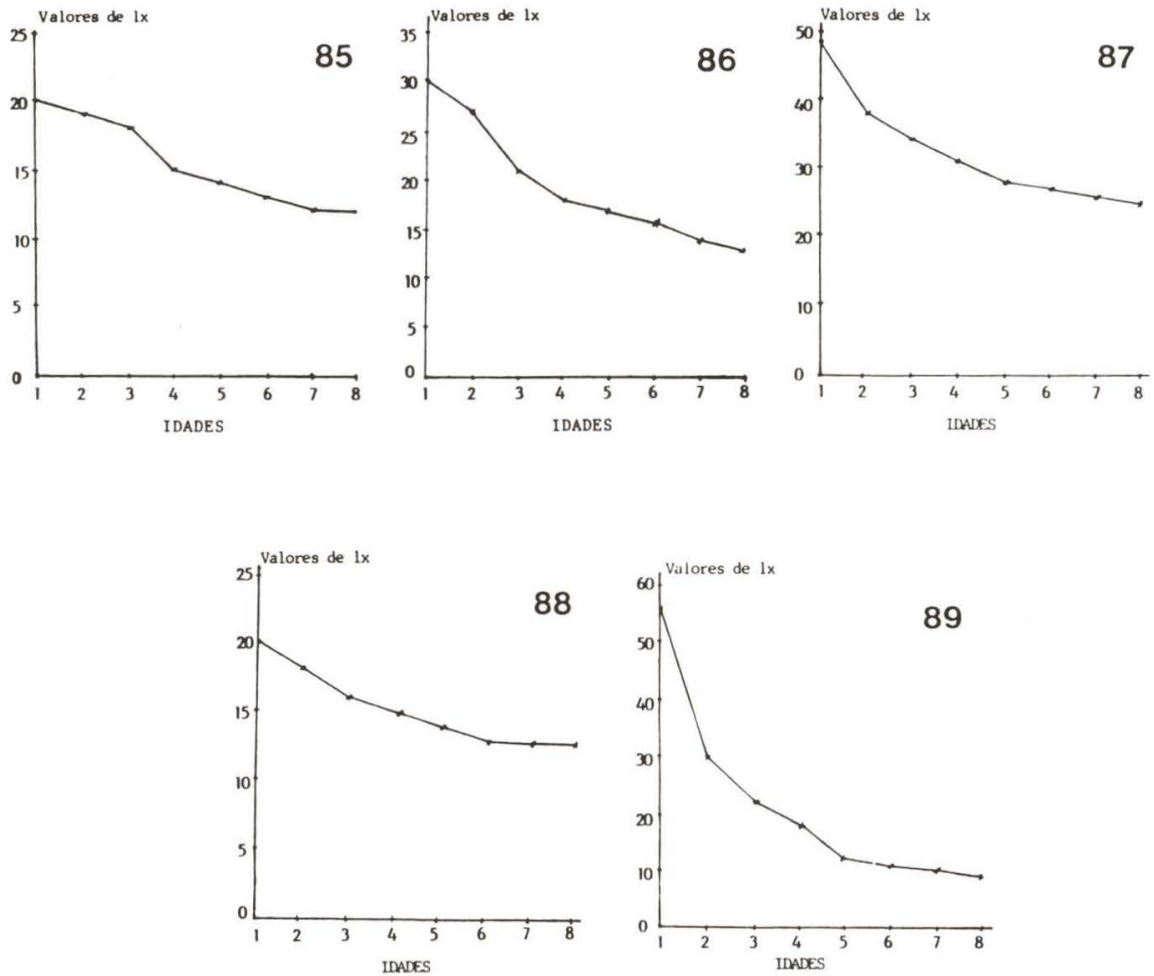

Figs 85-89. Curvas de Sobrevivência. (85) Anacassis dubia; (86) A. fuscata; (87) A. fuscata (forma); (88) A. languida; (89) A. phaeopoda. Idades: (1) Ovo, (2-6) instares larvais, (7) pupa; (8) adulto. 